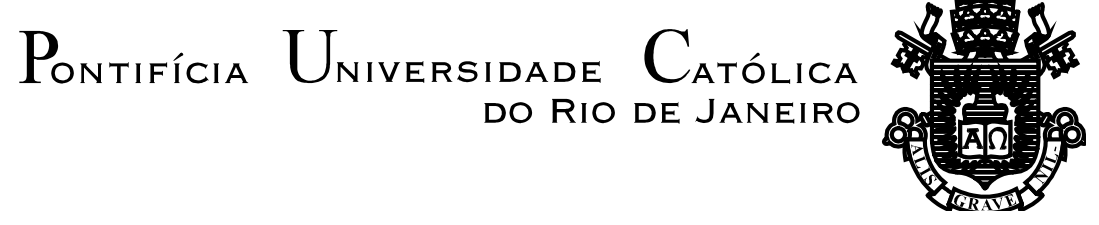

Vanessa Florentino Marcondes dos Reis

\title{
PRÁTICA EXPLORATÓRIA COMO FILOSOFIA DE VIDA: UM ESTUDO DE CASO
}

Dissertação apresentada ao Programa de PósGraduação do Departamento de Letras da Pontifícia Universidade Católica do Rio de Janeiro como requisito parcial para obtenção do título de Mestre em Letras.

Orientadora: Profa. Inés Kayon de Miller 

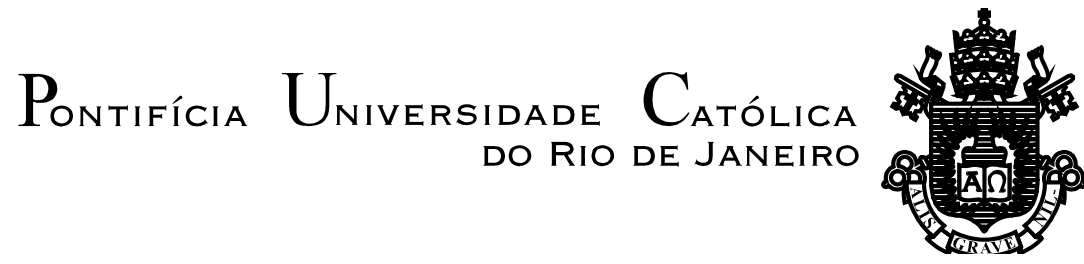

Vanessa Florentino Marcondes dos Reis

\title{
PRÁTICA EXPLORATÓRIA COMO FILOSOFIA DE VIDA: UM ESTUDO DE CASO
}

\begin{abstract}
Dissertação apresentada como requisito parcial para obtenção do grau de Mestre pelo Programa de Pós-Graduação Estudos da Linguagem do Departamento de Letras do Centro de Teologia e Ciências Humanas da PUC-Rio. Aprovada pela Comissão Examinadora abaixo assinada.
\end{abstract}

Profa. Inés Kayon de Miller

Orientadora

Departamento de Letras - PUC-Rio

Profa. Adriana Nogueira Accioly Nóbrega Departamento de Letras - PUC-Rio

Profa. Isabel Cristina Rangel Moraes Bezerra UERJ

Profa. Denise Berruezo Portinari Coordenadora Setorial do Centro de Teologia e Ciências Humanas - PUC-Rio

Rio de Janeiro, 24 de agosto de 2012. 
Todos os direitos reservados. É proibida a reprodução total ou parcial do trabalho sem autorização da universidade, da autora e da orientadora.

\section{Vanessa Florentino Marcondes dos Reis}

Graduou-se em Direito pela Universidade Federal do Rio de Janeiro em 2004, e em Licenciatura em Letras Português - Inglês pela Universidade Estácio de Sá em 2009. Obteve uma Certificação Internacional para o Ensino da Língua Inglesa (CELTA - Certificate of English Language Teaching for Adults) da Universidade de Cambridge, em 2007, na Inglaterra. Lecionou inglês em escolas privadas e cursos de idiomas, e atualmente faz parte do corpo docente do IPEL Línguas.

Ficha Catalográfica

Reis, Vanessa Florentino Marcondes dos

Prática exploratória como filosofia de vida: um estudo de caso / Vanessa Florentino Marcondes dos Reis ; orientadora: Inés Kayon de Miller. 2012.

$151 \mathrm{f.} ; 30 \mathrm{~cm}$

$$
\text { Dissertação (mestrado) - Pontifícia }
$$
Universidade Católica do Rio de Janeiro, Departamento de Letras, 2012.

Inclui bibliografia

1. Letras - Teses. 2. Prática exploratória. 3. Filosofia de vida. 4. Filosofia. 5. Estudo de caso. 6. Identidades. 7. Entendimentos. I. Miller, Inés Kayon de. II. Pontifícia Universidade Católica do Rio de Janeiro. Departamento de Letras. III. Título.

CDD: 400 
Para minha mãe e irmã, pelo amor, apoio e paciência.

Para meu pai, pela amizade de sempre. 


\section{Agradecimentos}

À minha irmã, Flávia, e minha mãe, Mara, pelo apoio em todos os momentos, e por acreditar em mim sempre.

Ao meu pai, pela paciência e por compreender minhas ausências.

À querida Gizele Rabello, professora exemplar e ser humano incrível, que sempre me incentivou no exercício diário de ensinar e amar.

À minha orientadora, Inés Kayon de Miller, pela paciência, apoio e suporte, até o final.

À querida Walewska Braga, pelas lições diárias de amor, calma, paciência, sabedoria e compreensão.

Aos amigos feitos durante o mestrado, sem vocês essa jornada teria sido mais difícil.

Aos amigos de alma, que estão sempre ao meu lado, desde sempre e para sempre.

À PUC-Rio pelo auxílio concedido que permitiu a realização deste trabalho. 


\section{Resumo}

Reis, Vanessa Florentino Marcondes dos; Miller, Inés Kayon de. Prática

Exploratória como filosofia de vida: um estudo de caso. Rio de Janeiro, 2012. 151p. Dissertação de mestrado- Departamento de Letras, Pontifícia Universidade Católica do Rio de Janeiro.

Motivada pelos relatos da professora Walewska Braga e de seus alunos nos encontros do grupo da Prática Exploratória, decidi aprofundar meu entendimento sobre as ideias centrais da Prática Exploratória (Allwright \& Hanks, 2009) e sobre como a professora consegue usar seus princípios e proposições para nortear sua vida profissional e pessoal. Para isso, foram realizados dois encontros com a professora Walewska: primeiro uma entrevista, transcrita e lida por ambas as participantes, e após uma conversa sobre a entrevista anterior, que também foi transcrita. Houve também a participação da autora desta dissertação em aulas ministradas pela professora, com a co-construção de um diário dessas aulas, e trocas de e-mails entre ambas durante esse período. A microanálise de trechos selecionados da entrevista e da conversa foi realizada com base (a) no modelo de tomada de turnos de Sacks, Schegloff e Jefferson (1974), (b) no conceito de sobreposições cooperativas (Tannen (2010), e (c) da análise da narrativa como estratégia de envolvimento (Tannen, 1984); e foi complementada com a reflexão sobre trechos selecionados dos e-mails e do diário. A análise teve como foco o meu processo de convencimento sobre a viabilidade da Prática Exploratória, que é uma filosofia de ensino-aprendizagem que busca estimular o pensamento críticoreflexivo, na medida em que integra o questionamento e o trabalho pedagógico, através de atividades pedagógicas com potencial exploratório (APPE). Nesse processo, a Prática Exploratória integra as pessoas nesse trabalho e na criação de espaços para refletir sobre as relações entre colegas e sobre a relação entre os alunos e o professor. Com isso, espera-se que tornem-se cada vez mais autônomos e reflexivos, ao mesmo tempo em que continuam se desenvolvendo linguisticamente, através de comportamentos que incentivem o pensamento 
crítico, ao mesmo tempo que possibilitam que o professor cumpra o conteúdo programático estipulado pelo colégio e pelo governo. Através de uma reflexão analítica sobre as identidades projetadas por Walewska, juntamente com a dinâmica de tomada de turnos, sobreposições cooperativas, e análise da narrativa como estratégia de envolvimento, aliados aos Princípios e Proposições da Prática Exploratória, busquei melhor compreender a sala de aula exploratória de Walewska Braga, e como essa professora incorporava a Prática Exploratória em todos os aspectos da sua vida em sala de aula e fora dela. A minha busca por um melhor entendimento da Prática Exploratória como um modo de viver as experiências do cotidiano, como uma filosofia de vida, resultou no presente trabalho, que também se constituiu na realização de uma Atividade Pedagógica de Potencial Exploratório.

\section{Palavras-chave}

Prática Exploratória; Filosofia de vida; Filosofia; estudo de caso; identidades; entendimentos. 


\section{Abstract}

Reis, Vanessa Florentino Marcondes dos; Miller, Inês Kayon de (Advisor). Exploratory Practice as a philosophy of life: a case study. Rio de Janeiro, 2012. 151p. MSc. Dissertation - Departamento de Letras, Pontifícia Universidade Católica do Rio de Janeiro.

Motivated by the various accounts given by teacher Walewska Braga and her students in the meetings of the Exploratory Practice group, I decided to deepen my understanding about the main ideas of Exploratory Practice (Allwright \& Hanks, 2009) and about how this teacher manages to use its Principles and Propositions as guidance for her personal professional life. For that purpose, two meetings were held: first an interview, transcribed and read by both participants, and afterwards a conversation about the previous interview, which was also transcribed. The author of this dissertation participated in classes given by the teacher, wrote a journal of these classes, and exchanged e-mails with the teacher during this period. The micro analysis of the selected passages of the interview was done based on (a) the turn-taking model proposed by Sacks, Schegloff e Jefferson (1974), (b) the concept of cooperative overlap (Tannen, 2010), and (c) the analysis of narrative as involvement strategies (Tannen, 1984); and was complemented with my reflection over excerpts selected from the e-mails and the journal. The focus of the analysis was my process of gradual understanding and growing conviction about the viability of the Exploratory Practice, which is a teaching-learning philosophy that aims to stimulate critical-reflexive participation by integrating questioning and pedagogic work, through Potentially Exploitable Pedagogical Activities (PEPAs). In this process, Exploratory Practice integrates people in this work and in the creation of opportunities to reflect about the relationships between teacher and students as co-practitioners. With Exploratory Practice, teachers and students are expected to become increasingly more independent and reflexive, as they continue to develop linguistically, through actions that prompt critical thinking, while enabling the teacher to carry out the curriculum designed by the school or the government. Through an analytical 
reflection about the identities projected by Walewska Braga, together with the dynamics of turn-taking, cooperative overlap and the analysis of narratives as involvement strategies, together with the Principles and Propositions of the Exploratory Practice, I looked for a better comprehension of Walewska's exploratory classroom, and how she incorporated Exploratory Practice in all aspects of her life in and outside school. My search for a better understanding of Exploratory Practice as a way of dealing with life, as a philosophy of life, resulted in this paper, which also turned out to be a Potentially Exploitable Pedagogical Activity.

\section{Keywords}

Exploratory Practice; Philosophy of Life; Philosophy; case study; identities; understandings. 


\section{Sumário}

$\begin{array}{ll}\text { 1. Introdução } & 13\end{array}$

2. Fundamentos Teóricos 18

2.1. A era do pós-método 19

2.2. A Prática Exploratória 26

2.2.1. Cinco proposições da Prática Exploratória 34

2.2.2. Os princípios da Prática Exploratória 36

2.3. A Prática Exploratória como filosofia de vida 40

2.4. A construção da identidade 42

3. Metodologia 45

3.1. A pesquisa qualitativa na Linguística Aplicada 45

3.2. Como foi feita a pesquisa 49

3.3. Minha trajetória profissional 51

3.4. Quem é Walewska Braga 54

3.5. A escola, as reuniões e os encontros 57

3.6. O arcabouço teórico-metodológico da Prática 58

Exploratória na pesquisa

$\begin{array}{ll}\text { 3.7. Instrumental Microanalítico } & 60\end{array}$

4. Análise 63

4.1. A entrevista e a conversa 63

4.2. As anotações sobre as aulas 100

5. Considerações Finais 106

6. Referências Bibliográficas 111

$\begin{array}{ll}\text { 7. Anexos } & 119\end{array}$ 


\section{Lista de Quadros}

Quadro 1- Entrevista, Trecho 1 65

Quadro 2 - Entrevista, Trecho 1

Quadro 3- Entrevista, Trecho $2 \quad 68$

Quadro 4- Entrevista, Trecho $3 \quad 69$

Quadro 5- Entrevista, Trecho $4 \quad 69$

Quadro 6- Conversa, Trecho $2 \quad 70$

Quadro 7- Entrevista, Trecho 5

Quadro 8- Conversa, Trecho $3 \quad 74$

Quadro 9- Entrevista, Trecho $6 \quad 76$

Quadro 10- Entrevista, Trecho $7 \quad 78$

Quadro 11- Entrevista, Trecho 7 82

Quadro 12- Entrevista, trecho $8 \quad 85$

Quadro 13- Entrevista, Trecho $9 \quad 86$

Quadro 14- Conversa, Trecho $4 \quad 87$

Quadro 15- Entrevista, Trecho $9 \quad 90$

Quadro 16- Entrevista, Trecho $9 \quad 92$

Quadro 17- Entrevista, Trecho 10

Quadro 18- Entrevista, Trecho $13 \quad 96$ 


\section{Convenções de Transcrição ${ }^{1}$}

\begin{tabular}{|l|l|}
\hline Símbolos & Especificações \\
\hline$\ldots$ & Pausa não medida. \\
\hline$\cdot$ & Entonação descendente ou final de elocução. \\
\hline, & Entonação de continuidade. \\
\hline sublinhado & Parada súbita. \\
\hline MAIÚSCULA & Fala em voz alta ou muita ênfase. \\
\hline$\uparrow$ & Subida de entonação. \\
\hline$\downarrow$ & Descida de entonação. \\
\hline [ & Fausa preenchida, hesitação ou sinais de atenção. \\
\hline [ palavra< & Fala mais rápida ou acelerada. \\
\hline [ ou :: & Alongamentos. \\
\hline [../ & Finalicio de sobreposição de falas. \\
\hline
\end{tabular}

\footnotetext{
${ }^{1}$ Adaptada de TANNEN (1989)
} 


\section{Introdução}

Pensar, todos pensamos. Uma ideia, uma frase, uma cor, uma lembrança, tudo é pensamento. No início do século XX, Dewey (1910, p.3) abordou especificamente o pensamento reflexivo:

Os homens pensavam que o mundo era plano, até que Colombo pensou que ele era redondo. O pensamento anterior era uma crença já enraizada, pois os homens não possuíam energia ou coragem de questionar aquilo que lhes havia sido ensinado, especialmente porque acreditava-se ser algo confirmado por fatos óbvios e sensatos. Mas o pensamento de Colombo foi uma conclusão razoável. Foi um estudo dos fatos com escrutínio, através da revisão de evidências, considerando-se hipóteses diversas, e comparando esses resultados teóricos com outros e também com fatos conhecidos. Colombo ousou pensar que o mundo era redondo porque não aceitou sem hesitação a teoria tradicional vigente na época, porque ele duvidou e pesquisou. Cético daquilo que parecia o mais correto e crédulo daquilo que parecia impossível, ele continuou refletindo até que pode produzir evidência que comprovasse sua hipótese. Mesmo que ele tivesse chegado à conclusão errada, teria sido um tipo diferente de crença daquela que ele rejeitou, pois teria sido alcançada por um método distinto. Atividade, persistência, e a análise cuidadosa de qualquer crença ou suposta forma de conhecimento à luz daquilo que a sustenta, e as consequentes conclusões a serem obtidas, constituem pensamento reflexivo. (grifos do próprio autor). ${ }^{2}$

O pensamento reflexivo, propulsor de mudanças, estabelece novos paradigmas. Infelizmente, muitas vezes, ao invés de duvidarmos, de investigarmos, costumamos optar por aceitar o que nos é dito como sendo uma

\footnotetext{
${ }^{2}$ Tradução livre de "Men thought the world was flat until Columbus thought it to be round. The earlier thought was a belief held because men had not the energy or the courage to question what those about them accepted and taught, especially as it was suggested and seemingly confirmed by obvious sensible facts. The thought of Columbus was a reasonable conclusion. It marked the close of study into facts, of scrutiny and revision of evidence, of working out the implications of various hypotheses, and of comparing these theoretical results with one another and with known facts. Because Columbus did not accept unhesitatingly the current traditional theory, because he doubted and inquired, he arrived at his thought. Skeptical of what, from long habit, seemed most certain, and credulous of what seemed impossible, he went on thinking until he could produce evidence for both his confidence and his disbelief. Even if his conclusion had finally turned out wrong, it would have been a different sort of belief from those it antagonized, because it was reached by a different method. Active, persistent, and careful consideration of any belief or supposed form of knowledge in the light of the grounds that support it, and the further conclusions to which it tends, constitute reflective thought. (DEWEY, 1910, p.3) (grifos do próprio autor)
} 
verdade irrefutável e, muito orgulhosos, nos consideramos pessoas inteligentes por sabermos recitar uma lista considerável de informações adquiridas ao longo de anos de estudo. Entretanto, informação sem reflexão pode tornar uma pessoa mais culta, mas não necessariamente mais sábia. Absorver sem nenhum pudor ou crítica o que nos é dito pela sociedade, nos torna massa de manobra. Segundo Benjamin (apud Kramer, 2002, p.60), "Na realidade, conhecimento sem conexão com a práxis, conhecimento que nada ensina ao proletariado sobre sua situação de classe, não é perigoso para os opressores".

Se não soubermos refletir sobre o que aprendemos, não seremos capazes de articular o conhecimento adquirido com a realidade, e portanto, não poderemos propor mudanças conscientes. Essa reflexão leva a um entendimento, a uma consciência crítica que, aliada à ação, define quem propõe a mudança, e quem a aceita sem sequer projetar ou se preparar para as consequências daí advindas.

Segundo Paulo Freire:

O educando recebe passivamente os conhecimentos, tornando-se um depósito do educador. Educa-se para arquivar o que se deposita. Mas o curioso é que o arquivado é o próprio homem, que perde assim seu poder de criar, se faz menos homem, é uma peça. O destino do homem deve ser criar e transformar o mundo, sendo o sujeito de sua ação. $(1979$, p.38)

A esse respeito, Giroux (1999) defende que a aprendizagem, para se tornar crítica, tem que ser significativa. Do mesmo modo, Freire e Fagundez (1985) defendem uma pedagogia da pergunta, de modo a estimular a criatividade e o pensamento crítico dos alunos. Para eles, a pedagogia escolar é uma pedagogia de respostas, que ensina os alunos a absorverem e adaptarem-se à realidade existente, sem, contudo, jamais questioná-la. Desse modo, cessa o diálogo nas escolas, instrumento essencialmente democrático e essencial para a formação de pensadores. O professor fala e o aluno escuta, aceita, memoriza. Segundo Rubem Alves, “(...) muito do que a escola faz é matar a ideia da paixão pela curiosidade” (2004, p.31).

A política pública adotada é crucial para que ocorra essa passagem de homem-receptor para homem-produtor de conhecimento. É necessária uma 
mudança significativa na forma como é pensada/realizada a educação hoje em dia. Segundo Kramer:

Não pode, pois, uma política pública pretender instalar o novo deixando de perceber o sempre igual, sob pena de - embora comprometa-se ao nível do discurso com a mudança, com a liberdade e a dignidade, com a igualdade e a justiça - favorecer tão-somente a repetição, a mesmice, a massificação e a manutenção das desigualdades. (2002, p. 47)

É lugar comum dizer-se que na escola aprendemos sobre o passado de modo a preparar-nos para o futuro. Mas e o presente? Não seria melhor dizer que aprendemos para que possamos realizar mudanças mais conscientes no momento presente? Porque o que temos de tangível é o momento presente, já que o futuro nunca estará ao nosso alcance.

Mas, novamente, para que sejam realizadas mudanças, inovações, a habilidade da reflexão crítica é indispensável. A educação deve ser vista não apenas como uma acumulação de saberes, mas como o desenvolvimento de uma consciência crítica que transforma o homem de objeto em sujeito da própria educação. Segundo Paulo Freire, "o homem deve ser o sujeito de sua própria educação. Não pode ser o objeto dela. Por isso, ninguém educa ninguém" (1979, p.28).

Nas palavras de Kramer (2002):

(...) ah! Quantas ilusões nos projetos pedagógicos modernizadores... De quantas novidades falam, e quanta mesmice propagam...Será que existe alguma outra instância da vida social, pergunto, que seja afeta a propostas de mudanças e tão desafeta a mudanças de fato? O pior é que existe sim. A escola é apenas um exemplo; reles exemplo de uma sociedade moderna onde tudo precisa mudar, para que tudo se mantenha inalterado... (p.51)

Seguindo essa linha de raciocínio, uma professora de uma escola municipal do Rio de Janeiro, Walewska Braga ${ }^{3}$, procura adotar, em sua prática diária, a reflexão, e transmitir isso aos seus alunos. Adepta da Prática Exploratória (Allwright, 1996), filosofia que visa despertar o pensamento reflexivo, essa

\footnotetext{
${ }^{3}$ A professora autorizou o uso de seu nome verdadeiro para esse trabalho.
} 
professora baseia-se em Princípios, que serão explicitados no próximo capítulo, a fim de que sua sala de aula torne-se um celeiro do pensamento crítico.

Longe de procurar doutrinar alguém, acredito ser verdadeiramente interessante observar os desdobramentos dessa prática em sala de aula, uma vez que vimos que tal atitude, apesar de considerada muitas vezes, na teoria, o objetivo maior do processo educativo, não costuma ser executada. Importante também é vermos os desdobramentos dessa atitude nos estudantes, acostumados a serem receptáculos de informação, inseridos na ótica conteudista e positivista ocidental, avessa a mudanças, e que visa mantê-los na mesma classe social de onde se originaram.

A partir do estudo desse caso, cabe a cada um de nós refletir e pensar criticamente, por nós mesmos. Não pretendo que aceitem o que digo como verdade inexorável, até porque tal atitude iria de encontro ao que acredito. Gostaria de despertar a curiosidade, a reflexão. Ao invés de uma resposta, proponho perguntas. Por que não?

Para esse fim, minhas perguntas de pesquisa, norteadoras dessa dissertação, são as seguintes: Como a professora Walewska integra a Prática Exploratória $^{4}$ à sua vida escolar e à sua vida cotidiana? Quais as identidades projetadas por Walewska durante o processo de pesquisa? Como se deu o meu processo de entendimento sobre a Prática Exploratória e sua viabilidade?

Este trabalho pretende focar, em seu corpo, no desenvolvimento de um pensar crítico no ambiente escolar, e na formação de alunos e professores transformadores da realidade social. Acredito que a reflexão, praticada habitualmente, nos proporciona outra visão de nós mesmos, uma consciência do indivíduo no mundo. Afinal, é isso que o homem pós-moderno procura, ao correr avidamente aos consultórios psicológicos e terapias comportamentais atualmente: um profissional que o ajude a pensar e refletir criticamente sobre si próprio, sobre sua vida, suas ações. Já foi dito anteriormente, perdemos essa capacidade. Ou simplesmente não temos tempo. Defendo, nesse trabalho, o pensar crítico na escola, na sociedade, em todas as esferas da vida do ser humano.

\footnotetext{
${ }^{4}$ A Prática Exploratória é uma prática pedagógica reflexiva e inclusiva que será apresentada no capítulo 2 .
} 
Assim sendo, começo por expor brevemente os fundamentos teóricos. Nessa parte, além de mais uma vez referir-me à necessidade de se incentivar o pensamento crítico, discorro sobre a falibilidade presente nos métodos de ensino em geral, já que não há um método de ensino que seja ideal para toda e qualquer pessoa e/ou situação social. A seguir, segue-se uma breve explicação da Prática Exploratória, de modo a familiarizar o leitor com o que considero ser uma filosofia de vida.

No capítulo de metodologia, discorro sobre o porquê de ter realizado uma pesquisa qualitativa, e explicarei a importância dessa forma de análise neste trabalho. Também abordarei o instrumental teórico que será utilizado na análise de dados. Nesse capítulo faço, também, uma breve exposição sobre a minha trajetória profissional, e como eu me interessei sobre o assunto por mim pesquisado e tema do presente trabalho. Inicialmente, eu não conseguia vislumbrar a exequibilidade da Prática Exploratória na sala de aula, e essa dissertação mostra o meu processo de convencimento, através das interações com Walewska Braga (uma entrevista e uma conversa), além da observação das aulas. Há também, é claro, uma seção sobre a professora Walewska Braga, que é personagem central e crucial para esse estudo. A seguir, estudo o caso de Walewska, e procuro entender suas razões e as suas impressões sobre o resultado de suas práticas. Na microanálise do discurso gerado na entrevista e na conversa informais busco momentos que sinalizem a aproximação entre o meu entendimento e o de Walewska a respeito da viabilidade do exercício da Prática Exploratória. Assim, os dados serão obtidos a partir da transcrição dessas conversas, que constam nos anexos III e IV.

Nas considerações finais, relato o que eu aprendi ao escrever e estudar este tema, retomo as minhas perguntas de pesquisa e procuro relacionar, mais uma vez, os meus entendimentos a essa filosofia de vida chamada Prática Exploratória. 


\section{2 \\ Fundamentos Teóricos}

Van Mannen (1977 apud Liberali 2008) descreveu três tipos de reflexão: a reflexão técnica; a reflexão prática e a reflexão crítica.

$\mathrm{Na}$ reflexão técnica, o professor aplica um conhecimento técnico às suas ações, sem que ele saiba efetivamente o porquê de ele ter escolhido essa ação para determinada situação. Não se busca um entendimento mais profundo, há um foco na resolução de problemas, eficiência e eficácia, e a teoria é a fonte de onde são retiradas as técnicas utilizadas. Não há em realidade reflexão, há aplicação.

A reflexão prática é marcada basicamente por relatos entremeados por avaliações pessoais, e a tentativa de compreender os eventos a partir de sua própria experiência e conhecimento de mundo. Verifica-se, em tais casos, que os professores tomam atitudes baseadas no senso comum somente. Há o desejo de transformação e compreensão, mas isso efetivamente não acontece, pois não se problematizam as premissas.

Já na reflexão crítica, conforme Liberali (2008, p. 38):

Partindo da premência emancipatória de o sujeito ser capaz de analisar sua realidade social e cultural (Liberali \& Zyngier, 2000) e tomar uma posição frente aos acontecimentos de forma a desenvolver possibilidades de transformá-lo, a reflexão crítica retoma características tanto da reflexão técnica como da prática; contudo, coloca foco nas questões éticas como centrais.

A reflexão crítica não somente busca, mas apresenta a real possibilidade de se chegar a uma transformação social. Através do pensamento crítico, o educador dá voz ativa aos estudantes ao longo de seu processo de aprendizagem, utiliza a linguagem para discutir o cotidiano, e, juntos, construírem um entendimento acerca de qualquer situação. Dessa maneira, todos aprendem, pois todos se tornam praticantes reflexivos, e qualquer transformação torna-se mais viável (Schön, 1991). 
Paulo Freire (1985), com sua pedagogia da pergunta, Giroux (1999) e Rubem Alves $(2004,2010)$, todos defendem a criatividade e a curiosidade na sala de aula, de modo a estimular a reflexão crítica e a formação de cidadãos conscientes, transformadores da realidade social.

$\mathrm{Na}$ busca por uma sala de aula mais crítica, menos homogeneizada, e mais atenta às necessidades e ao desenvolvimento individual de alunos e professores, Kumaravadivelu (2003) propõe a era do pós-método, que será abordada a seguir, a fim de contextualizar a Prática Exploratória como uma abordagem de ensinoaprendizagem.

\section{1}

\section{A era do pós-método}

Cada ser humano, cada pessoa, cada cidadão, cada aluno, é único, no sentido de não existirem duas pessoas exatamente iguais (Arnold \& Brown, 1999, p.8). Assim sendo, deve-se sempre procurar respeitar as idiossincrasias, e isso é um dos fatores que torna a atividade docente tão complexa: o fato de se ter que ensinar dezenas (às vezes centenas) de alunos diariamente, cada um com um ritmo diferente de aprendizado, com preferências e habilidades distintas, e cada qual imerso em universos dos quais o professor pouco ou nada conhece, e que igualmente influenciam o desempenho do aluno em sala de aula (aliás, na vida em sociedade em geral).

Portanto, sendo uma verdade aceita que cada ser humano é diferente do outro, por que insistimos em esperar que se comportem da mesma maneira, pensem da mesma maneira, ajam da mesma maneira e aprendam da mesma maneira?

Esbarramos, portanto, nas concepções de ensino e aprendizagem. Ligadas a cada uma delas, desenvolveram-se diversas metodologias, que se propõem a explicitar, passo-a-passo, técnicas de ensino que, se corretamente aplicadas, obteriam êxito. Dentre as várias concepções de ensino e aprendizagem, falaremos 
aqui da concepção do professor tecnicista ${ }^{5}$ (Kumaravadivelu, p. 8-13), segundo a qual o professor funciona como um conduto, transmitindo conhecimento ao aluno. Escolhi apenas essa abordagem para ilustrar a dissertação por ser ela extremamente oposta ao pós-método, e mesmo à Prática Exploratória, e, portanto, ser mais fácil de compreender as oposições:

Professores e seus métodos de ensino não são considerados muito importantes porque sua eficácia não pode ser comprovada empiricamente. Portanto, os programas de formação de professores concentram-se mais no aspecto da formação do que no professor. Esta visão passou a ser conhecida como visão tecnicista do ensino e da formação de professores. (Kumaravadivelu, 2003, p.8) ${ }^{6}$

Ou seja, como nunca conseguiu-se avaliar a eficácia dos métodos (The Pensylvania Foreign Language Research Project - Allwright, 2003), tenta-se assegurar que os professores adotem irrestritamente uma determinada metodologia, como se a falibilidade dos métodos fosse consequência da máaplicação dos mesmos pelos professores.

A visão tecnicista não busca valorizar ou estimular o espírito crítico ou reflexivo, mas tão somente a absorção e fixação do conteúdo ensinado pelos alunos. "Para esta tendência, o ensino é um processo de condicionamento através do uso de reforço das respostas que se quer obter, sendo o conteúdo as informações objetivas que possam proporcionar, ao fim do processo, a adequada adaptação do indivíduo ao trabalho." (http://sites.google.com/site/ged0611/tecnicista acesso em 27/12/2011)

Em outras palavras, em uma sala de aula com trinta alunos, trinta indivíduos, bastaria aplicar uma mesma metodologia, e todos aprenderiam satisfatoriamente a matéria ensinada. Ora, mas como esperar que pessoas

\footnotetext{
${ }^{5}$ Apesar de aqui abordarmos apenas a concepção tecnicista, há ainda as concepções tradicional, humanista, espontaneísta, construtivista, mistas etc. Optei por abordar apenas uma, a título de exemplo. Além disso, a visão tecnicista, por ser uma das mais opostas ao pós-método e da prática exploratória, torna mais evidentes as características dessas últimas, que são mais relevantes para esse trabalho.

${ }^{6}$ Tradução livre de: "Teachers and their teaching methods are not considered very important because their effectiveness cannot be empirically proved beyond doubt. Therefore, teacher education programs concentrate more on the education part than on the teacher part. Such a view came to be known as the technicist view of teaching and teaching education."
} 
diferentes aprendam a mesma coisa da mesma maneira? Parece-me um contra senso.

Sette, em sua tese de doutorado, intitulada $A$ vida na sala de aula: ponto de encontro da Prática Exploratória com a Psicanálise, diz (p 16):

(...) a metodologia adotada nas salas de aula é orientada pela perspectiva comportamentalista, a qual, segundo Corrêa (2002:43), "se baseia na transmissão de informação, que considera o aluno como receptor de informações necessárias à sua formação". (...)

Assim, essa forma de ensino assume um fluxo comunicacional unidirecional, "em que o professor transmite informações para os alunos, o que impossibilita o diálogo, a interação, mantendo os alunos como meros receptores da informação, sem nenhuma possibilidade de interlocução" (Corrêa, idem:44)

É exatamente essa passividade que, a meu ver, se deve evitar. Os adultos, os professores, constantemente reclamam da falta de capacidade reflexiva e argumentativa dos mais jovens, mas como esperar que eles desenvolvam habilidades que não são estimuladas, sendo, na maioria das vezes, consideradas negativas? A criança que muito questiona, que faz perguntas embaraçosas, é considerada, por vezes, mal criada e mal educada.

Assim, alguns professores se frustram por julgarem sua culpa a não aprendizagem de todos os alunos de maneira igualmente "eficiente" (deixando eficiência para ser interpretada de acordo com a proposta pedagógica de cada instituição escolar), já que, claramente, alguns alunos irão aprender com mais facilidade, outros com mais dificuldade, quando expostos ao mesmo método. Muda-se o método, e a situação permanece a mesma, alternando apenas os alunos que apresentam dificuldade e facilidade no processo de aprendizagem. E, ainda assim, continuam culpando professores e métodos pelos baixos resultados obtidos no ensino de língua estrangeira. (Richards e Rodgers apud Silva).

Um dos problemas com os métodos é que "[o] bom ensino é considerado aquele que usa corretamente o método, seus Princípios e técnicas preestabelecidas" (Richards \& Rodgers, 2001, p.244). Nessa perspectiva não se considera o papel ativo do aprendiz, nem suas crenças, estilos, preferências, objetivos, necessidades e interesses. O mesmo, em geral, acontece em relação aos(às) professores(as) que ficam limitados(as) a reproduzir modelos e receitas que não permitem análises 
críticas e não consideraram fatores como experiência profissional, objetivos, desejos, motivações etc. (Silva, 2004)

Além disso, como o grupo responsável por pesquisar e descobrir o "melhor método" não costuma ser o mesmo grupo que ensina, cabendo aos professores apenas acatarem as conclusões dos pesquisadores, verifica-se um verdadeiro abismo entre teoria e prática, o que também justifica a dificuldade que professores e alunos têm de adaptar-se às metodologias e soluções mágicas para as situações cotidianas de sala de aula que lhe são oferecidas. (Silva, 2004).

Kumaravadivelu (2003, p18) endossa essa visão crítica, ao afirmar que tal separação assemelha-se àquela entre consumidor e comerciante, na qual o professor comporta-se como mero consumidor. Giroux (1999, p. 26) compartilha da mesma opinião, ao afirmar que "a proletarização do professor tornou os educadores muitos dependentes e impotentes". Ou seja, por conjunturas políticosociais, o educador não possui, muitas vezes, tempo para desenvolver um pensamento crítico ou uma pesquisa. O professor é também uma vítima do sistema (Alves e Dimenstein, 2004, p. 97). E aí, ele torna-se mero consumidor ${ }^{7}$. De acordo com Giroux:

(...) o conhecimento é subdividido em partes diferentes, padronizado para serem mais facilmente gerenciados e consumidos, e medidos através de formas de avaliação predeterminadas. (...)

O que fica claro nessa abordagem é que a mesma organiza a vida escolar em torno de especialistas em currículo, instrução e avaliação, aos quais se reserva a tarefa de concepção, ao passo que os professores são reduzidos à tarefa de implementação. (...) Não é preciso dizer que os Princípios subjacentes às pedagogias de gerenciamento estão em desacordo com a premissa de que os professores deveriam estar ativamente envolvidos na produção de matérias curriculares adequados aos contextos culturais e sociais em quais ensinam. (1997, p.160)

\footnotetext{
7 "Consequentemente, existe, como mencionado anteriormente, uma divisão correspondente de trabalho entre o teórico e o professor: o teórico pensa e constrói o conhecimento e o professor entende e aplica esse conhecimento. Portanto, a relação entre o teórico e o professor não é diferente daquela entre o produtor e o consumidor de um produto comercial." Tradução livre de: Consequently, there is, as mentioned earlier, a corresponding division of labor between the theorist and the teacher: the theorist conceives and constructs knowledge and the teacher understands and applies that knowledge. Thus, the relationship between the theorist and teacher is not unlike that of the producer and the consumers of a commercial commodity." (KUMARAVADIVELU, 2003, p.18)
} 
O professor é capaz de, ele mesmo, avaliar sua sala de aula e, junto com seus alunos, construir um ambiente de aprendizado que estimule a criatividade, o pensamento crítico e o diálogo. Infelizmente, o que tem se visto, cada vez mais, é a dissociação dos professores e sua função de educar, no sentido mais amplo do termo, colocando-os em um papel meramente tecnicista. Os alunos são quantificados e não possuem voz, já que o professor, na maior parte das vezes, possui mínima ingerência sobre o que será lecionado em sua sala de aula e como a matéria será ensinada e avaliada. Há metas a cumprir (como, por exemplo, número de alunos/clientes matriculados, exames vendidos, aprovações no vestibular) e pouco tempo disponível. Professores e alunos se tornam dados, e não há tempo nem espaço a ser 'gasto' com práticas reflexivas, tão cruciais para a transformação da nossa sociedade.

Mas, se trabalhamos com uma diversidade de alunos, porque se restringir a apenas um método para ensinar dúzias de alunos diferentes? O pós-método, portanto, propõe que cada professor avalie, desenvolva e reflita sobre o seu próprio ensino, independente de um método específico. O professor do pósmétodo é um professor autônomo, crítico-reflexivo e engajado (por uma necessidade interna e não externa, provocada por seu empregador) em sua formação continuada.

Kumaravadivelu (2003, p.11) define o professor reflexivo como um profissional que busca examinar e solucionar os dilemas surgidos na sala de aula; que está consciente de suas escolhas ao ensinar; que está atento ao contexto institucional e cultural de onde ele trabalha; participa da elaboração curricular; é engajado nas atividades escolares; é responsável pelo próprio desenvolvimento profissional. Mas, se o próprio professor não é crítico, como ele vai lidar com as opções pedagógicas ao seu dispor? Como ele será capaz de formar alunos críticos?

Apesar da visão do professor como um profissional reflexivo ser um enorme avanço com relação à visão do professor tecnicista, entre outros, é importante ressaltar que é necessário que o professor seja crítico, e torne a reflexão uma atividade interativa que envolva toda uma comunidade. É no sentido de reflexão crítica, aliás, que Kumaravadivelu procurou definir o professor 
reflexivo. Além disso, falta, na visão de Kumaravadivelu, uma maior atenção aos fatores políticos e sociais que influenciam a prática diária do profissional de ensino.

Dessa maneira, trago aqui a visão do professor como um intelectual transformador (Giroux, 1999), embasada na filosofia educacional de Paulo Freire (1979, 1985) e sua pedagogia crítica. A pedagogia deve, em última análise, fortalecer aprendizes e educadores, ao ensiná-los a pensar e refletir criticamente, a serem agentes transformadores da sociedade, ao invés de meramente reprodutores da realidade existente.

Para o professor transformador, a adoção de um método de ensino não é, portanto, capaz de levar em consideração as inúmeras variáveis de uma sala de aula, “(...) métodos são baseados em conceitos idealizados orientados para satisfazer contextos idealizados". (Kumaravadivelu, 2003, p.28).

É necessário um professor que seja capaz de pensar e repensar suas práticas, experimentar, pesquisar, dar voz ao aluno, co-construir uma sala de aula híbrida e particular - porque cada sala de aula é una. Não é tarefa fácil, pois, na maior parte das vezes, o aluno não aceita a própria voz, esperando apenas absorver aquilo que é recitado pelo professor. Ele duvida de sua própria capacidade crítica, e o professor tentará contornar essa situação. Claro que o professor foi, muitas vezes, ele mesmo, educado de maneira a não refletir, a não experimentar, e, a não emitir opinião que estivesse em desacordo com aquilo que a comunidade escolar pregava. O professor também pode ter sido educado de acordo com a 'pedagogia da resposta' (Freire \& Faundez, 1985); portanto, tornarse um professor transformador constitui-se em um duplo desafio.

(...) nenhum de nós tem a verdade, ela se encontra no devir do diálogo; como dizia Hegel, "a verdadeira realidade é o devir", não é o ser nem o não ser, mas a tensão entre ambos - o processo histórico é o verdadeiro. Assim, quando se propõe que o verdadeiro é uma busca e não um resultado, que o verdadeiro é um processo, que o conhecimento é um processo e, enquanto tal, temos de fazê-lo e alcançá-lo através do diálogo, através de rupturas, isto não é aceito pela grande maioria dos estudantes que se acham acostumados com que o professor, hierarquicamente, tenha a verdade, ele o sábio, e portanto não aceitam o diálogo.

\footnotetext{
${ }^{8}$ Traducão livre de “(...) methods are based on idealized concepts geared toward idealized contexts".
} 
Para eles o diálogo é sinal da fraqueza do professor, para eles a modéstia no saber é mostra de fraqueza e ignorância. (Freire \& Faundez, 1985)

A discussão do pós-método reacende a importância do pensar, ao invés do simplesmente aceitar. Questionar, ao invés de obedecer. Esperar e observar, ao invés de se angustiar. Elaborar perguntas, ao invés de recitar respostas padronizadas (Freire \& Faundez, 1985). O professor deve possibilitar que seus alunos reflitam sobre seu papel na sociedade, e em como a linguagem serve a esse mesmo propósito. É a sala de aula como local de conscientização. Isso é um professor-pesquisador, alguém que está inserido no ambiente a ser pesquisado, que o entende e o compreende melhor, e que está consciente que o que quer que seja realizado em uma sala de aula não necessariamente deverá ser aplicado em outra, em virtude da heterogeneidade dos contextos.

Com relação à implementação de teorias de pesquisadores externos à sala de aula do professor, uma das questões problemáticas é que uma sala de aula possui um número de variáveis tão grande que torna-se inviável a comprovação objetiva de qualquer teoria (Allwright \& Bailey, 1991). Afinal, toda sala de aula é uma combinação exclusiva de pessoas com personalidades e históricos diferentes, e, portanto, nenhuma hipótese que, por ventura, se confirme em uma sala de aula, será necessariamente validada e funcionará em outra sala de aula. Portanto, penso que o ideal é que o próprio professor seja também pesquisador (Allwright, 2003a, 2003b; Allwright \& Hanks, 2009) já que é ele que convive diariamente com os alunos e, além disso, ele próprio funciona de maneira singular quando inserido naquele ambiente, e isso também deve ser levado em consideração. Afinal, professores diferentes desenvolvem relacionamentos distintos com o mesmo grupo de alunos.

O professor é um indivíduo com crenças, afetos e hábitos, e isso influencia muito a sala de aula. Por tudo isso, ele é o mais indicado para pensar, refletir e realizar qualquer tipo de pesquisa em sua sala. Por tudo isso, acredito no empoderamento do professor, e na sua figura como pesquisador-praticante (Allwright \& Hanks, 2009; Allwright, 1996), que será discutida na próxima seção. 


\section{2}

\section{A Prática Exploratória}

O pós-método preocupa-se em ampliar o horizonte do professor, dando-lhe mais possibilidades de trabalho intelectual, crítico e reflexivo. Entretanto, procura-se obter, ao final, um resultado específico, definido anteriormente. É a qualidade do trabalho, do serviço prestado (em tempos atuais, em que a relação educacional passou a ser uma relação de consumo), que é o objetivo final. Mas, e se deixássemos esse afã imediatista, essa necessidade de resultados, de lado? E se, ao invés de iniciarmos uma jornada já pensando em seu fim, nos concentrássemos no caminho? Como já disse a escritora norte-americana Ursula K. LeGuin "É bom ter um fim para a jornada, mas é a jornada que importa no fim”.

Segundo Allwright (apud Sette, p. 51-52), embora nas décadas de 60 e 70 a Linguística Aplicada focasse na qualidade do trabalho realizado em sala de aula, buscando sempre "prescrever procedimentos mais eficazes", atualmente, entendese que "o professor não é o único responsável pelos acontecimentos no contexto pedagógico". Desse modo, há uma mudança de foco, e ao invés da busca incansável de solução de problemas, passa-se a buscar o entendimento do que acontece em sala de aula (a vida em sala de aula). Entendo que questões locais, pertencentes a uma comunidade, devem ser trabalhadas/entendidas localmente, respeitando-se assim a idiossincrasia dos integrantes daquela comunidade (no caso, o professor e seus alunos). Para a Prática Exploratória, e para outros pesquisadores (cf Gieve and Miller, 2006), nenhuma situação social pode ser

generalizada e transformada em dados para posteriormente criar-se uma fórmula a ser aplicada todas as outras vezes que situação similar ocorrer. Portanto, o que importa, para a Prática Exploratória, é a qualidade de vida em sala de aula, pois daí advém a satisfação e produtividade tanto do professor quanto do aluno, garantindo-se assim a "saúde mental" de ambos (Allwright, 2006; Gieve \& Miller, 2006). Atualmente, o que se vê é exatamente o contrário: alunos extremamente insatisfeitos e inconformados com a sala de aula, e professores esgotados física e mentalmente. Alinho-me a Miller (2013) quando diz que: 
(...) a Prática Exploratória oferece oportunidades para que as pessoas compartilhem questões sobre as "tristes realidades vividas em sala de aula" (cf. sad realities, ALLWRIGHT, comunicação pessoal; MILLER, in ALLWRIGHT \& HANKS, 2009, p. 245; SILVEIRA, em andamento) ou sobre vivências do "sofrimento humano" (MUSHAKOJI, 1999, p.207, in MOITA LOPES, 2006, p.86). (...) Allwright (2008) e Allwright \& Miller (no prelo) propõem a Prática Exploratória na formação inicial de professores como um possível antídoto péprofissional para a síndrome de 'burn-out' (esgotamento).

A sindrome de burnout é hoje uma triste realidade que reflete a má qualidade de vida em sala de aula. De acordo com Silva et al (2008):

Os agentes estressores são classificados em duas categorias: eventos externos e internos. Os eventos externos, dizem respeito aos fatos existentes no ambiente e às relações que a pessoa estabelece com estes fatos, envolvendo questões profissionais, pessoais e sociais. No caso dos professores, podemos mencionar: mau comportamento dos alunos, precárias condições de trabalho, pressões por razões de tempo, excesso de atividades, carga horária elevada, deteriorização das relações com colegas de trabalho, estrutura física inadequada, baixos salários, desvalorização da profissão (Kyriacou, 2003; Cruz; Scherer; Peixoto, 2004).

Tais insatisfações, geradas por fatores externos, costumam ser trabalhadas por professores, futuros professores e, inclusive, alunos, dentro do paradigma da Prática Exploratória. Esses agentes exploratórios se preocupam com questões de qualidade de vida, porque não há o foco em resultados, e nem na busca de soluções (Miller, 2010, Allwright \& Miller, no prelo).

Ainda sobre a sindrome de burnout, e citando novamente Silva et al (2008):

Já os eventos internos estão relacionados a pensamentos, emoções, valores, comportamentos, vulnerabilidades biológicas ou psicológicas, inatas ou adquiridas (LIPP, 2004), ligadas ao mundo particular do indivíduo e sua forma de resposta às situações cotidianas, contemplando aspectos tais como: auto-cobrança e senso de responsabilidade exagerado, perfeccionismo, auto-estima baixa, esperar sempre aprovação e elogios externos (pais, alunos, diretores), negativismo, expectativas elevadas ou metas irrealistas, necessidade de controlar tudo o tempo todo e de não delegar trabalho aos outros por achar que pode fazer melhor; medo do desemprego.

Nota-se que uma má qualidade de vida para o professor em sala de aula também gera uma má qualidade de vida para o aluno, pois ambos encontram-se 
em uma situação de dependência mútua. Um professor esgotado vê a sala de aula como um fardo, e o aluno como um obstáculo à sua felicidade. As consequências dessa atitude podem ser muito negativas.

A Prática Exploratória constitui-se em uma filosofia de ensinoaprendizagem que visa, também, estimular o pensamento crítico-reflexivo. Entende-se a Prática Exploratória como um "trabalho para entender" (work for understanding, cf. Allwright, 2003), que pode ocorrer em diversos contextos, isto é, é um trabalho pedagógico e investigativo ao mesmo tempo.

\begin{abstract}
A Prática Exploratória opta pela busca de entendimentos mais profundos (a ação para entender) ao invés da resolução precipitada de problemas (a ação para a mudança) e cria oportunidades para os praticantes exploratórios se 'apaixonarem' pelas questões, pela prática de questionar. (Miller et al, 2008, p. 147)
\end{abstract}

A Prática Exploratória trabalha com puzzles, ou questões, a serem melhor entendidas. O professor e os alunos, sozinhos ou em conjunto, refletem sobre alguma questão que os intriga, os revolta, os deixa desconfortáveis, ou orgulhosos (por que não?), enfim, qualquer coisa sobre a qual desejem obter um entendimento mais profundo. Após refletir sobre os diferentes pontos de vista que inevitavelmente existirão sobre a mesma questão, e sentindo-se mais confiante e seguro, o grupo poderá optar para agir para mudar a situação, ou não. Allwright (2009) ${ }^{9}$ mostra alguns exemplos de puzzles como o relato de Ana Raquel (p.241), que conta como a sua turma resolveu investigar a questão "Por que é tão difícil aprender matemática?"10 e como eles refletiram sobre a questão ao escutar a opinião de outros professores e alunos, e aprenderam juntos. A pura reflexão sobre o assunto já mostra uma mudança de atitude dos alunos em relação à questão. Também há um relato bastante interessante da professora Walewska Braga (p. 241-242) que mostra que uma aluna sua, ao dizer que o inglês ensinado na escola não os preparava para o mercado de trabalho, incentivou todos a pesquisarem sobre o uso de inglês na vizinhança. Os alunos conseguiram respostas interessantes e puderam apresentar seus trabalhos e refletir posteriormente, em conjunto, sobre a situação deles com relação ao ensino de

\footnotetext{
${ }^{9}$ O capítulo 15 do livro Understanding the Language Learner está repleto de exemplos de puzzles.

${ }^{10}$ Tradução livre de "Why is it so difficult to learn Maths?"
} 
inglês em sala de aula. Pediram à professora Walewska que intensificasse o trabalho oral e eles passaram a ter uma aula de prática oral em inglês por semana, e foram atendidos. Nesse caso, o puzzle gerou, além da mudança interna, uma mudança factual (ou seja, eles passaram a ter uma aula de prática oral de inglês, que eles não tinham), pois eles entenderam melhor o que eles queriam.

A reflexão continuada almejada pela Prática Exploratória propicia a seus praticantes uma visão mais ampla da situação que se deseja entender, ao invés de deixá-los atados a uma perspectiva imediatista, que leva a uma falsa idéia de que para qualquer situação problemática há uma solução simples e eficaz, bastando que a encontremos. Citando Allwright, "tentar entender um problema [é] uma forma de mudar seu status de 'problema a ser resolvido' para 'questão com a qual conviver'” (Allwright, 2002, p.60).

A Prática Exploratória defende uma nova relação entre pesquisa, prática e teoria, onde o pesquisador/teórico seria também o practitioner. Assim, o próprio professor e seus alunos são os pesquisadores. E assim, pesquisando, buscando entender a sua sala de aula, professores e alunos põem em prática o pensamento reflexivo (Van Lier, 1994). Segundo Stenhouse (apud Van Lier, 1994): "Não é suficiente que o trabalho dos professores seja estudado: eles próprios precisam estudá-lo."11

Quando outras pessoas, alheias à realidade da sala de aula, atuam como pesquisadores-consultores, a reflexão crítica normalmente deixa de ser feita por professores e alunos, como se o entendimento deles, protagonistas da relação estudada, fosse menos válido.

Prática Exploratória, de maneira diversa de outras abordagens da pesquisa do praticante, foi desenvolvida precisamente para esse objetivo - possibilitar aos praticantes da sala de aula de línguas, professores e alunos, desenvolver seu próprio entendimento sobre o ensino e a aprendizagem, e simultaneamente continuar com seu desenvolvimento linguístico. ${ }^{12}$

\footnotetext{
${ }^{11}$ Tradução livre de "It's not enough that teacher's work should be studied: they need to study it themselves".

12 Tradução livre de "Exploratory Practice (see Allwright and Lenzuen, 1997), unlike other approaches to practitioner research, has been developed for precisely this purpose - to enable language classroom practitioners, both teachers and learners, to develop their own understandings
} 
Além de uma maior agentividade e inclusividade dos agentes que costumam ser passivos objetos de pesquisa, outro ponto positivo da Prática Exploratória é que, contrariamente ao que pode parecer à primeira vista, a busca pelo entendimento não visa acarretar uma sobrecarga de trabalho para professores e alunos. O professor não precisa parar as atividades pedagógicas de sala de aula para dedicar-se ao puzzle, mas deve aproveitar algo que está sendo ensinado e "utilizar uma atividade pedagógica, já conhecida, como ferramenta de investigação para introduzir uma reflexão a respeito de algum questionamento dele ou dos alunos" (Sette, p.62).

Essa integração entre as práticas usuais da sala de aula e questionamentos trazidos pelos alunos ou pelo professor recebe o nome de APPE - Atividade Pedagógica com Potencial Exploratório (PEPA, no original, Allwright \& Hanks, 2009, p.157), e a sala de aula de ensino de línguas é considerada um ambiente bastante propício para o desenvolvimento dessas atividades, pois, por exemplo, discussões sobre temas variados na língua alvo são uma prática frequente e o tema pode ser um puzzle (Allwright \& Hanks, 2009, p.155). Miniestudos de caso foram narrados por Allwright \& Hanks (2009), com exemplos bem sucedidos de APPE, que ilustram a versatilidade com que os puzzles podem ser adaptados ao currículo escolar na sala de aula de línguas.

Em última análise, entendo que a Prática Exploratória é uma filosofia de vida que se caracteriza pela problematização, o diálogo e a flexibilização dos conteúdos de ensino. $\mathrm{O}$ entendimento das vivências integra-se à ação, há uma prioridade com relação à educação social, moral, integral do aluno/cidadão, há uma crença em um sistema educacional não-conteudista. Como já foi dito, acredito que saber entender, ouvir, escutar, dialogar, analisar e refletir é mais importante que saber recitar nomes e dados que serão brevemente olvidados. Essas são habilidades de suma importância para a vida em sociedade, para o desenvolvimento da inteligência de um indivíduo.

J.A. Gaiarsa, psiquiatra, em seu livro Educação familiar e escolar no novo milênio (2008), defende, sem fazer menção à Prática Exploratória, questões com 
as quais nos identificamos. O convite à experimentação, prática presente na Prática Exploratória, é ratificado por Gaiarsa. Para ele, os adultos acabam por tolher as crianças de experimentarem tanto quanto gostariam (e deveriam). Ele defende, entre outras coisas, dizer menos "não", substituí-lo por "por que não?", em um esforço legítimo de deixar a criança experimentar, e assim construir seus entendimentos, chegar às suas próprias conclusões.

Cada "não" produz uma parada de movimento (e do olhar), uma paralisação corporal, uma frustração emocional e um congelamento do interesse, da curiosidade, da busca, do desejo de experimentar. E uma onda de raiva, também contida, com um enrijecimento muscular difuso. (p.23)

Entendo que os que se alinham à Prática Exploratória não acreditam que a maioria das escolas tradicionais propiciem esse tipo de experiência, e Gaiarsa é da mesma opinião:

De cada dez pessoas, nove têm lembranças desagradáveis da escola. Sentados duas horas e depois mais duas, ouvindo coisas bem pouco interessantes de um adulto via de regra bem pouco interessado...Este é o maior pecado que se pode cometer em educação, ou contra as crianças: pretender ensinar a alguém, em classes de trinta ou mais alunos, noções pelas quais eles não têm nenhum interesse.(...)

(...)

A escola vale pelo recreio, pelas amizades, por um ou outro professor. Vale demais pelo início do relacionamento social.

\section{(...)}

Se os professores (e o senhor Ministro) fossem submetidos a exames a fim de estabelecer quanto sabem do que o programa pretende ensinar, o resultado seria catastrófico. Se no início de cada ano se aplicasse aos alunos uma prova digamos, de cem perguntas - sobre as matérias "aprendidas" no ano anterior, qual seria o resultado?

O que fica nas crianças é uma descrença e uma antipatia profundas pelo aprendizado, pela escola, pela inteligência, pela ciência, pela cultura, pela verdade...Até pela realidade (dos adultos)... (p.23-24)

Associo o pensamento de Gaiarsa à filosofia da Prática Exploratória por defender uma nova linha educacional, linha essa que estimula a independência, a criatividade, e a experimentação, ao invés de adestrar as crianças a serem passivos 
receptores de dogmas, incapazes de formularem seus próprios entendimentos. Como querer um mundo melhor se continuamos fazendo tudo igual? Como querer pessoas atuantes e inovadoras se a escola dedica-se a adestrar os futuros adultos a aceitarem o que lhes é imposto e memorizar - apenas memorizar, simplesmente, e sem a indicação de nenhuma utilidade imediata naquele ato - uma quantidade absurda de informação? Informação esta que estará, em breve, obsoleta, conforme defendem os autores a seguir:

Eu costumo dar palestras para executivos de grandes empresas, para empresários. Nesses encontros, muitas vezes, eu pergunto: Vocês sabem o que vai ser necessário saber daqui a cinco anos para continuar conduzindo suas empresas? Eles dizem que não sabem. E sabem o que os funcionários vão ter de saber daqui a cinco anos? Eles não sabem. Eles só sabem de uma coisa: que não podem parar de querer saber. (Alves \& Dimenstein, 2004, p.41 - grifos do próprio autor)

Não é mais como antigamente, quando as pessoas iam a um seminário e a informação tinha amplo prazo de duração. Um antibiótico era usado durante anos. Antigamente, um livro de referência era usado durante muitos anos. Vamos pegar um exemplo mínimo. A chegada dos homens à América. A cada semestre é divulgada uma teoria nova. (idem, p.103 - grifos meus)

A aula é expediente de informação, não propriamente de formação, sobretudo em auditórios numerosos; há diferença total entre informar e formar, sem falar que repassar informação ultrapassada sequer atende ao requisito de informar. (Demo, 2001, p.86 - grifos meus)

Ou seja, é importante ressaltar que, nos dias de hoje, a informação chega a nós constantemente, sempre atualizada. Concordo com os autores supracitados que a escola muitas vezes não atende a esse fluxo de informação, passando a ideia de que a informação obtida e memorizada ali é uma verdade absoluta, e não simplesmente uma teoria, passível de mudança. E, sendo assim, não seria melhor atenuar a necessidade de memorização desses dados, e prezar pelo entendimento, relativização e crítica?

O Instituto para o Desenvolvimento do Potencial Humano, sediado na Filadélfia, Pensilvânia (EUA), desenvolveu pesquisas que provam como um sistema educacional diferenciado (e mais exploratório) estimula de maneira muito mais eficaz o cérebro das crianças (Gaiarsa, p 84-89).

Novamente, considero que tal postura se coaduna com a Prática Exploratória, pois não há o medo de se "perder o controle" das crianças, ou 
mesmo o apego aos métodos tradicionais. A busca pelo estímulo constante, a busca por novos entendimentos, o convite à experimentação, à reflexão, o deixar a criança descobrir/aprender o que lhe interessa, em seu próprio tempo. São práticas que vão de encontro à sala de aula tradicional, ao conteúdo linear, dividido anualmente ou semestralmente, ao despejo de informação que deve ser absorvida irrefletidamente e prontamente pelos alunos. Segundo Gaiarsa, isso não desenvolve a inteligência de ninguém. Muito pelo contrário, ao tratar todas as dezenas de alunos em uma mesma sala de aula como iguais, sujeitando-os todos aos mesmos conteúdos, a serem absorvidos (e não entendidos), o que há é uma uniformização, que vai de encontro à diversidade humana. Estou de acordo com Gaiarsa, quando ele se dirige ao leitor e diz:

Pense bem, leitor: tanto a família quanto a escola pretendem uniformizar as crianças. Se a sociedade fosse uniformizada como o Exército, tudo seria mais fácil. "Ordem Unida". Basta um comando e todos obedecem sem pensar. Se considerarmos as frases que acompanham preconceitos, a semelhança se torna visível (p.215)

A Prática Exploratória busca gerar entendimentos locais, ao invés de verdades absolutas. Professores exploratórios procuram engajar as pessoas envolvidas em uma mesma realidade social para melhor compreendê-la, e assim lidar melhor com suas conquistas e frustrações. Não há procedimentos específicos e tampouco regras para isso, o que é há é um desejo de entendimento e de integração. A maior mudança proposta pela Prática Exploratória é uma mudança de perspectiva (Allwright \& Hanks, 2009).

A seguir, discorrerei brevemente sobre alguns conceitos-chave e Princípios da Prática Exploratória que serão utilizados frequentemente no próximo capítulo, ao analisar duas salas de aula exploratórias. 


\title{
2.2.1
}

\section{Cinco proposições da Prática Exploratória}

A Prática Exploratória parte de cinco Proposições, a saber (cf. Allwright \& Hanks, 2009, p. 4 - 10):

1. Aprendizes são indivíduos únicos que aprendem e se desenvolvem melhor em sua própria idiossincrasia;

2. Aprendizes são seres sociais que aprendem e se desenvolvem melhor em um ambiente de apoio mútuo;

3. Aprendizes são capazes de levar o aprendizado a sério;

4. Aprendizes são capazes de tomar decisões independentemente;

5. Aprendizes são capazes de se desenvolverem como praticantes do próprio aprendizado.

A primeira afirmação é aparentemente óbvia, mas é interessante como a sociedade, em geral, trata os alunos como uma massa única, homogênea. Ora, se a idiossincrasia é uma realidade, como esperar que todos aprendam com o mesmo método, com o mesmo livro, e com a mesma velocidade? Retornamos, assim, a um ponto já discutido anteriormente, mas que entendo ser necessário revisitar, devido à sua correlação com a primeira Proposição.

\begin{abstract}
A padronização do ensino também implica uma "visão universalista" dos alunos, os enxergando como uma "massa não diferenciada". (...) Espera-se que os indivíduos que pertencem a essa massa comportem-se da mesma maneira, como se fossem clones, ao invés de se comportarem como um grupo de indivíduos ímpares em um meio essencialmente social. Isso significa que faz sentido procurar "o melhor" método de ensino, como se algum método pudesse ser o melhor para qualquer pessoa em qualquer lugar. (Allwright \& Hanks, 2009, p.9) ) $^{13}$
\end{abstract}

Invariavelmente, aqueles que não se adequam ao programa de ensino vigente são considerados indivíduos com dificuldade de aprendizagem ou desinteressados. Em muitos casos, uma simples mudança de enfoque seria o suficiente.

\footnotetext{
${ }^{13}$ Tradução livre de: "Standardising teaching also implies a "universalistic view" of learners, seeing them as an 'undifferentiated mass' (...) The individuals in the mass are expected to act just like each other, as clones might, rather than as a group of unique individuals in an essentially social setting. This implies that it makes sense to look for 'the one best' teaching method, as if any one method could be the best for everybody everywhere."
} 
A segunda afirmação nos faz refletir sobre o fato de que os alunos respondem a pressões sociais em sala de aula (e não me refiro aqui, tão somente, à "pressão" dos professores). Eles devem se conformar, também, com as regras dos outros grupos aos quais pertencem. Constantemente, eles, aos construírem suas identidades em relação ao outro, tentam corresponder às expectativas de diferentes grupos sociais ao mesmo tempo, o que gera um conflito interno, que é inerente ao ser humano, já que somos seres sociais. Claro que esse fato está presente em nossa sala de aula, e em nossas relações com os alunos. Assim, apesar dos conflitos (e também devido a eles), o aprendizado proporcionado pelo convívio em grupo é extenso (e intenso), e isso acontece porque o conflito (e a vida em sociedade gera conflito) gera uma reflexão que, consequentemente, leva a um aprendizado.

A terceira afirmação leva, a meu ver, a um desafio. A falta de motivação dos alunos é o tipo de crença amplamente disseminada, em meios acadêmicos ou não acadêmicos. Igualmente conhecida, outra crença nos diz que as pessoas tendem a se comportar da maneira que esperamos que elas se comportem. Portanto, se partirmos do pressuposto de que os alunos não são motivados, eles provavelmente não demonstrarão nenhuma motivação. E eis que surge o desafio: esperar sempre o melhor de todo e qualquer aluno, apesar da aparente falta de interesse/motivação/aptidão etc. Não acho que seja fácil, e acho que eu, até hoje, consegui pouquíssimas vezes. Professores são humanos, não super-heróis. De qualquer maneira, começar acreditando no potencial dos alunos é, em minha opinião, um grande passo para uma melhora da qualidade de vida em sala de aula.

A quarta Proposição nos propõe enxergar nossos alunos de uma maneira mais autônoma: acreditar que eles podem ser (e efetivamente são) responsáveis pelo próprio aprendizado). Portanto, as escolhas cabem a eles. "Nenhum professor ensina se não houver consentimento dos alunos ${ }^{14 "}$ (Cortis apud Allwright \& Hanks, 2009, p.2). Para que se aceite essa afirmação é preciso que se esteja confortável com a situação de não se estar no controle. A maioria dos professores é ensinado a "manter o controle da classe" sempre, e enxergar essa relação de maneira diversa é difícil e ameaçador. Mas, como dar autonomia aos alunos sem dar-lhes o direito de escolha? Como esperar pensamento crítico e voz ativa se em

\footnotetext{
${ }^{14}$ Tradução livre de "No teacher teaches except by consent."
} 
sala de aula não se tem voz e são considerados bons alunos os que se conformam com as normas e não expõem opiniões divergentes?

A última Proposição apresenta a visão do aluno como um praticante, ou seja, o aluno como responsável pelo seu próprio processo de aprendizado, que é construído juntamente com o professor e demais membros da comunidade escolar. O aluno não é mais um mero receptor de conteúdos, mas possui participação ativa em todo o processo.

Como já foi dito anteriormente, as propostas da Prática Exploratória encontram diversos empecilhos à sua aplicabilidade plena:

(...) a enorme pressão para se adaptar às demandas nacionais e institucionais para uma padronização: assegurar responsabilidade seguindo o currículo oficial, ensinando da maneira oficialmente aprovada e preparando alunos para os exames impostos pelas autoridades. Essa pressão pela padronização desprofissionaliza os professores. ${ }^{15}$ (Allwright \& Hanks, 2009, p.7)

Apesar das dificuldades citadas acima, ao adotarmos a Prática Exploratória como filosofia de vida, ela acabará influenciando também a nossa sala de aula. Isso porque nossas identidades pessoais e profissionais permeiam tudo o que fazemos. Portanto, ao tornar-nos seres exploratórios, seremos também professores exploratórios, e estaremos contribuindo para uma melhora em nossa qualidade de vida, e também na qualidade de vida daqueles a nossa volta. É um ganho comunitário.

\subsection{2}

\section{Os princípios da Prática Exploratória}

De maneira a melhor se conseguir fazer entender o que é a Prática Exploratória, foram elaborados alguns Princípios. Entretanto, tais Princípios não

\footnotetext{
15 Tradução livre de: "The often overwhelming pressure to conform to national institutional demands for standardization: to ensure accountability by following the official curriculum, by teaching in the officially approved way and by preparing learners for the examinations that the authorities impose. This pressure for standardization de-professionalises teachers."
} 
devem ser vistos, absolutamente, de maneira prescritiva. Há que se considerar que a Prática Exploratória como filosofia de vida, como forma de enxergar e refletir sobre o mundo, vai muito além de conclusões tomadas em conjunto e colocadas em um papel. Há que se considerar que a verdade não é una. De acordo com Miller, Cunha \& membros do grupo da PE, 2009, p.218:

(...) nós não temos seguido os Princípios da PE como guias e que nossas práticas tampouco os ilustram. Mas, que os próprios Princípios resultam de práticas exploratórias sobre as quais refletimos coletivamente. Em uma relação simbiótica, os Princípios e nossas práticas são o que fazemos e aquilo em que acreditamos. (grifos da própria autora).

A versão mais difundida dos Princípios da Prática Exploratória é a seguinte (Miller et al: 2008, p.147)

Priorizar a qualidade de vida;

Trabalhar para entender a vida na sala de aula ou em outros contextos profissionais;

Envolver todos nesse trabalho;

Trabalhar para a união de todos;

Trabalhar para o desenvolvimento mútuo;

Integrar esse trabalho com as práticas de sala de aula ou com outras práticas profissionais;

Fazer com que o trabalho para o entendimento e a integração sejam contínuos.

A priorização da qualidade de vida é o baluarte da Prática Exploratória, já que considera-se o tempo e nossa vida pessoal e profissional como bens de imensurável valia. Logo a seguir, vem a valorização do entendimento.

Erroneamente, muitos julgam ser a Prática Exploratória contra qualquer tipo de mudança ou tentativa de mudança. Entretanto, o profissional reflexivo não irá realizar nenhuma ação para a mudança antes de entender a situação em si. É preciso entender o que quer que esteja acontecendo em qualquer que seja a situação social, para, então, decidir-se se é desejável uma mudança, ou não. Às vezes, a mudança mostra-se desnecessária, às vezes descobre-se outra perspectiva 
de encarar a situação e suas conclusões mudam. Nas palavras de Allwright \& Hanks (2009, p.151):

“(...) talvez devêssemos reafirmar aqui que a PE não é contra a mudança, apenas contra a mudança não inteligente, e contra a pressão burocrática por mudança e a falta de um esforço para entender". ${ }^{16}$ (grifos dos próprios autores)

O envolvimento de todos no trabalho vem da possibilidade que todos os participantes têm de desenvolverem seu próprio entendimento acerca dos fatos. A Prática Exploratória é contra a existência de um entendimento 'dominante' ou 'correto'. Nenhum entendimento é definitivo, porque as próprias relações sociais não são definitivas, a sociedade é um organismo em constante mudança. Cada participante, portanto, ao refletir e discutir suas idéias e percepção dos fatos com os outros participantes, não somente se desenvolve como cidadão reflexivo e participante pesquisador, mas ajuda também no desenvolvimento de seus colegas (Princípio 5). E todos juntos, trabalhando em conjunto, fortalecem a união e a noção de comunidade (Princípio 4).

O Princípio 6 merece uma atenção especial, a meu ver. Digo isso pois é muito comum a descrença na possibilidade sugerida por essa afirmativa, e isso comprometeria a proposta de um trabalho exploratório. É de suma importância que o explorar da prática não se torne mais uma obrigação ou dever de casa para professores e alunos. Portanto, o processo de entendimento/reflexão deve ocorrer conjuntamente com as obrigações cotidianas. A pesquisa não deve ser extra, deve ser integrada, deve fazer parte da aula. Como exemplo, relatarei brevemente sobre o trabalho exploratório que a professora Walewska Braga realizou em sala de aula, conjugando o trabalho gramatical sobre a reflexão sobre o comportamento dos alunos.

E não era fácil aceitar a falta de concentração, a inquietação, a "bagunça"... No meio de uma bronca uma aluna disparou... "Professora, o problema é que você gostaria de dar aulas para anjos e nós... somos uns demônios!”

$\mathrm{E}$, assim, começando a aprender que meus alunos tinham muito a me dizer, decidi investigar, com eles, uma nova questão: “Quem é o meu aluno?” (...) Na época eu

\footnotetext{
${ }^{16}$ Tradução livre de: “(...) we should perhaps reaffirm that EP is not against change, only against unintelligent change, and against bureaucratic pressure for change in the absence of an effort to understand".
} 
estava trabalhando com os verbos no Imperative Form e preparando o próximo ponto gramatical: Simple Present. Aproveitei a oportunidade e o grande interesse deles para trabalharmos com o vocabulário que eles queriam usar, advérbios de frequiência, formas afirmativas e negativas dos verbos no "Simple Present Tense". "Anjos", disseram eles, não conversam, não comem na sala, são educados, chegam sempre na hora, estudam e fazem dever de casa. "Demônios/vampiros" nunca estudam, ficam nos corredores, colam nas provas, matam aula, comem biscoito, balas, chiclete durante a aula. Das nossas reflexões vimos que, com alguma negociação, poderiam surgir os "Caspers", fantasminhas camaradas. "Caspers" conversam... mas fazem os exercícios, trazem "walkman" para a sala, mas só ouvem quando é possível, tentam não colar, são educados, fazem o dever de casa... algumas vezes.

Todas estas características foram sendo usadas para formar frases em inglês: "angels get very good grades"; "angels don't chew gum"; "vampires cheat in tests"; "vampires never study"; "caspers avoid cheating"; "caspers sometimes do their homework".

Por último, ao se afirmar que o trabalho para entendimento é contínuo, apenas ratifica-se o que já foi dito anteriormente: que, em se tratando de seres humanos, da vida em sociedade como um todo, a mudança é uma constante. E, assim sendo, a busca pelo entendimento também deve ser. É o adotar a postura exploratória para a vida, e na vida, para que não sejamos simplesmente consumidores de idéias e passemos a dar voz ativa às nossas próprias idéias e entendimentos. Citando, mais uma vez, Allwright \& Hanks (2006, p.153):

A vida é contínua e dinâmica. Portanto, nossos entendimentos são, na melhor das hipóteses, sempre provisórios e válidos, por um breve espaço de tempo, se chegarem mesmo a serem válidos. Nosso trabalho para entender, portanto, precisa ser uma jornada contínua. ${ }^{17}$

Esses Princípios nortearão a análise do estudo de caso, como será visto mais detalhadamente no próximo capítulo, e daí a importância de compreendê-los agora.

A Prática Exploratória nos possibilita uma pesquisa qualitativa e inclusiva, com ampla participação de todos os envolvidos, evitando assim a pesquisa parasítica, o esgotamento e procura cuidar da qualidade de vida dos envolvidos (c.f. third-party research, Allwright, 2006). É um meio “indefinidamente

\footnotetext{
${ }^{17}$ Tradução livre de "Life is continuous and dynamic. Our understandings are therefore always going to be provisional, at best, and valid only briefly, if at all. Our work for understanding, therefore, needs to be a continuous enterprise".
} 
sustentável" de se pesquisar/entender o mundo a nossa volta (comunicação pessoal, Miller)

\section{3}

\section{A Prática Exploratória como filosofia de vida}

Venho defendendo a minha visão da Prática Exploratória como filosofia de vida, e, por isso, considero importante explicar, ainda que brevemente (pois a proposta dessa dissertação é outra), essa minha postura aos leitores. Escolhi lidar com essa questão após a discussão dos Princípios e Proposições da Prática Exploratória, pois entendo ser esse entendimento essencial para que se compreenda essa afirmação.

Desde o surgimento da filosofia ocidental na Grécia antiga, até a pósmodernidade, o caráter crítico estabeleceu-se como um aspecto fundamental do pensamento filosófico. A filosofia é uma ciência que se auto-define também pela mudança constante, e essa abertura à discussão, à reformulação, a correções, está presente desde as primeiras escolas filosóficas.

Pós-modernamente essa postura persiste, de maneira, inclusive, mais acentuada, quando se observa que não é possível caracterizar a filosofia pósmoderna como uma corrente ou doutrina, e tampouco nela se encontra unidade teórica, metodológica ou sistemática. (Marcondes, 2007,p.279).

Marcondes (2007, p.279), ao escrever sobre a filosofia pós-moderna, diz:

$\mathrm{Na}$ verdade, o ponto em comum entre esse autores (pós-modernos) parece ser mais a necessidade de encontrar novos rumos para o pensamento, concebendo a filosofia de forma ampla e não linear, mais próxima das artes do que da ciência, não se pretendendo mais como um saber ou um ponto de vista privilegiado, mas como uma prática discursiva, uma forma de reflexão, um entendimento de nossa época e de nossa experiência que dê conta de suas rápidas transformações, de sua especificidade e de sua complexidade.(Grifos meus). 
A receptividade ao novo, o convite à crítica e ao debate, a necessidade de uma reflexão (crítica), configuram fortes pontos de contato com a Prática Exploratória. Sendo assim, posso afirmar que as características essenciais do pensamento filosófico também encontram-se presentes na Prática Exploratória, e portanto, considero adequado denominá-la de filosofia.

Além disso, compreendo a Prática Exploratória como um exercício diário, que transcende a sala de aula, e se mistura à nossa vida cotidiana. Os Princípios e Proposições da Prática Exploratória constituem um modo de se lidar com os fatos da vida, e não uma metodologia de ensino. Mais adiante, ao analisar a prática da professora Walewska Braga, mostrarei como determinados comportamentos da Prática Exploratória encontram-se presentes na maneira que a professora lida com os acontecimentos em geral.

A filosofia oriental, de maneira mais abrangente, aproxima-se da Prática Exploratória, e de sua noção de Princípios e Proposições, que buscam ajudar o indivíduo a tornar-se mais reflexivo e consciente de seu papel e importância na sociedade.

O budismo tibetano, por exemplo, lida com a questão de controle de maneira bastante similar a Allwright. Conforme esclarece Berzin:

\begin{abstract}
Nós estamos confusos com relação a toda a questão do controle. Nós cremos que é possível estar completamente no controle daquilo que acontece conosco. Por isso, nós nos frustramos. Não é possível estar sempre no controle. Isso não é a realidade. A realidade é bastante complexa. Muitas coisas influenciam aquilo que ocorre, não apenas o que nós fazemos. Não é que nós estamos totalmente sem controle ou sendo manipulados por forças externas. Nós contribuímoas para o que ocorre porém não somos o único fator que determina o que ocorre.
\end{abstract}

Allwright (2003c) reconhece a dificuldade que o profissional da educação tem ao tentar deixar de lado a questão de controle, e, com ela, a noção de metodologia. A busca da Prática Exploratória por entendimentos, ao invés do controle de comportamentos humanos, encontra eco nesse ensinamento filosófico.

Outro ponto de interseção entre a filosofia oriental e a Prática Exploratória é que, para os orientais, a meditação é uma prática reflexiva essencial para harmonizarmos o mundo à nossa volta, prática que gera uma mudança de dentro 
para fora. A Prática Exploratória também acredita que a busca pelo entendimento/reflexão é essencial, e que ela gera, sempre, uma mudança, embora o objetivo da reflexão não seja a mudança per se. Citando Dalai Lama, líder religioso do budismo tibetano, "Seja a mudança que você quer ver no mundo", ou seja, a verdadeira mudança inicia-se dentro de nós mesmos.

Nesse sentido, alinho a Prática Exploratória à filosofia oriental, por elas buscarem uma interpretação mais abrangente do ser humano, com orientações práticas para a vida, confundindo-se, algumas vezes, com religião, como ocorre com a filosofia budista $\left(\right.$ Salvaggio $\left.{ }^{18}\right)$.

Portanto, ao chamar a Prática Exploratória de filosofia de vida, faço uma aproximação preliminar com as filosofias ocidental e oriental, já que ela, de certa maneira, se alinha a ambas. Considero que esta conexão possa ser retomada no futuro.

\section{4 \\ A construção da identidade}

Iniciarei esta seção expondo brevemente três diferentes concepções de identidade, que surgiram em uma ordem cronológica ao longo dos séculos, refletindo as mudanças sociais do mundo ocidental.

A visão de sujeito do Iluminismo refletia uma concepção bastante individualista do sujeito e de sua identidade, com a pessoa humana vista "como um indivíduo totalmente centrado, unificado, dotado das capacidades de razão, de consciência e de ação (...)" (Hall, 2004, p.10). Essa essência do ser humano, sua identidade, permanecia a mesma durante toda a vida do indivíduo.

Mais tarde, o sujeito sociológico, acompanhando as transformações sociais do mundo moderno, entende que a identidade é formada no processo de interação

\footnotetext{
${ }^{18}$ Artigo retirado da internet em 13/06/2012, sem informação do ano. O link para acesso está nas Referências Bibliográficas.
} 
entre o sujeito e a sociedade que o cerca. A essência interior do sujeito, que seria sua "verdadeira identidade", existe, mas é constantemente transformada "num diálogo contínuo com os mundos culturais 'exteriores' e as identidades que esses mundos oferecem" (Hall, 2004, p.11).

Atualmente, chegamos à visão do sujeito pós-moderno, em seu infinito processo de construção identitária. O sujeito, que até então era visto como possuidor uma essência individual e inata, passa a ser considerado como conjunto de outras tantas identidades, como um sujeito plural, fragmentado (Hall, 2004). De acordo com essa concepção, as pessoas possuem múltiplas identidades sociais. Hall (2004, p.39) defende que ao invés de identidade, deveríamos falar de identificação, de modo a deixar clara a idéia de processo em andamento.

Essa visão de identidade abraça uma perspectiva anti-essencialista (Moita Lopes, 2003), e ratifica a visão de "identidades sociais como fragmentadas, contraditórias e em fluxo" (ibid, 2003, p.27).

As identidades sociais de classe social, gênero, sexualidade, raça, idade, profissão etc. são simultaneamente exercidas pelas mesmas pessoas nas mesmas ou em práticas discursivas diferentes. (Moita Lopes, 2002, p. 36)

Entender as identidades como construções sociais implica a idéia de movimento, de processo, de um conceito em transformação contínua, assim como é a sociedade. Desse modo, nossos discursos, que por vezes são divergentes, espelham nossas múltiplas identidades (Gee apud Moita Lopes, 2003, p.19).

Em uma analogia com a língua, não se pode fixar um significado para uma identidade, pois esse mesmo significado é mutável, ou seja, ele existe em relação a outro significado (Hall, 2004, p.40).

O conceito de identidade ajuda a entender a forma em que os indivíduos se agrupam ou as afinidades que os indivíduos encontram ou negociam entre si. Assim, pessoas se agrupam por serem brasileiras, ou francesas; outro grupo se forma por ser constituído de mulheres; outro por ter pessoas que estudaram em colégios particulares de elite; outro conjunto de pessoas que ficaram órfãs; mais um de refugiados de guerra...Cada um de nós projeta, a todo o tempo, dezenas de 
identidades, globalizadas, locais, misturadas (Hall, 2004). Mesmo não sendo o foco do meu trabalho, eu busco entender as construções identitárias de Walewska como membro do grupo da Prática Exploratória, e também como membro de outros grupos, buscando, assim, melhor compreender como a Prática Exploratória faz parte da sua vida.

Desse modo, em nossos discursos diários, nossas várias identidades sociais são construídas e negociadas, dependendo do que queremos projetar para o outro. A interação a ser analisada nesse trabalho, por passear por diversos momentos da vida das participantes, mostra diferentes identidades que são projetadas todo o tempo, simultaneamente.

Durante o processo discursivo, os significados são negociados entre os participantes da interação (Mishler, 1986 apud Rollemberg), o que sugere que Walewska e eu estaremos construindo e (re)construindo nossas múltiplas identidades e nossos múltiplos entendimentos durante o processo de pesquisa.

Dessa forma, o construto identidade me ajudou a construir Walewska como uma mulher, branca, esposa, de sessenta e um anos de idade, de classe média, professora, ex-aluna da PUC-Rio, ex-aluna de um colégio de freiras, membro do grupo da Prática Exploratória do Rio de Janeiro, e minha colega, constrói sua vida pessoal e profissional, e a fazer associações entre a filosofia exploratória e algumas das identidades sociais que Walewska Braga projeta. 


\section{3 \\ Metodologia}

Nesse capítulo abordarei a pesquisa qualitativa e sua importância no campo da Linguística Aplicada (doravante LA), bem como a Análise da Conversa, que será a base teórica utilizada na análise dos trechos transcritos da conversa que tive com a professora exploratória Walewska Braga.

Por último, explicarei, resumidamente, como foi feita a pesquisa.

\section{1 \\ A pesquisa qualitativa na Linguística Aplicada}

O desenvolvimento das ciências humanas ao longo dos séculos mostra como, a fim de angariar tanto respeito quanto as ciências exatas, os cientistas das áreas sociais voltaram-se para a tentativa de transformar questões sociais em dados objetivos e quantitativos. Entretanto, nesse campo específico, os modelos teóricos de base positivista falhavam ao fornecer respostas demasiado simplistas às complexas questões humanas (Sette, p.30). Citando Chizzotti (2000, p.78, apud Sette, p.30):

A hegemonia das pesquisas positivistas, que privilegiavam a busca da estabilidade constante dos fenômenos humanos, a estrutura fixa das relações e a ordem permanente dos vínculos sociais foi questionada pelas pesquisas que se empenharam em mostrar a complexidade e as contradições de fenômenos singulares, a imprevisibilidade e a originalidade criadora das relações interpessoais e sociais. Partindo de fenômenos aparentemente simples de fatos singulares, essas novas pesquisas valorizaram aspectos qualitativos dos fenômenos, expuseram a complexidade da vida humana e evidenciaram significados ignorados da vida social.

$\mathrm{Na}$ pesquisa qualitativa em ciências humanas há que se considerar "a natureza socialmente construída da realidade, a íntima relação entre o pesquisador 
e o que é estudado, e as limitações situacionais que influenciam a investigação" (Denzin \& Lincoln, 2006, p.23). A quantificação das variáveis a serem observadas em uma pesquisa no campo das ciências humanas e sociais é, muitas vezes, prescindível, quando o objetivo final do pesquisador é oferecer uma interpretação de uma realidade específica, através de um recorte de uma situação social. Alinhome com os pós-positivistas ao entender que qualquer realidade a ser estudada não é passível de plena análise e entendimento, principalmente levando-se em conta a diversidade de elementos a serem considerados e que são impossíveis de serem analisados em uma única pesquisa. A natureza diversificada de uma situação social faz com que ela funcione como um prisma, ou um cristal (Richardson apud Denzin \& Lincoln, 2006, p.19), que, dependendo do ângulo, refletirá um matiz diferente, desvelando, assim, um novo olhar. Ou seja, o modo de observar e interpretar de qualquer pesquisador ou analista será fatalmente influenciado por sua formação, suas origens, suas crenças e sua situação social (o efeito Rashomon, Wolcott, 1994, p. 21).

Considero bastante interessante essa relativização dos conceitos préexistentes acerca das pesquisas quantitativa e qualitativa para dar prosseguimento ao presente estudo. Na minha opinião, é mister tentar desconstruir o que se entende por sala de aula ideal, por comportamento esperado do corpo discente e docente. Citando Velho (1979, p.39), “O que sempre vemos e encontramos pode ser familiar mas não é necessariamente conhecido e o que não vemos e encontramos pode ser exótico mas, até certo ponto, conhecido". (grifos do próprio autor)

A natureza interpretativista do trabalho em muito colabora com esse objetivo.

(...) o processo de conhecimento da vida social sempre implica em um grau de subjetividade e que, portanto, tem um caráter aproximativo e não definitivo," (Geertz, apud Velho, p.42)

A realidade (familiar ou exótica) é sempre filtrada por um determinado ponto de vista do observador, ela é percebida de maneira diferenciada. Mais uma vez não estou proclamando a falência do rigor científico no estudo da sociedade, mas a necessidade de percebê-lo enquanto objetividade relativa, mais ou menos ideológica e sempre interpretativa. (Velho, p. 42-43) 
Assim sendo, entendo que quaisquer conclusões a que eu chegue nessa dissertação estarão eivadas de subjetividade, como é característico e esperado de pesquisas no campo das ciências humanas, como já foi discutido anteriormente. De maneira a exemplificar tal posição, cito Gilberto Velho, a respeito de uma pesquisa que realizou em um prédio de classe média baixa branca, tendo efetivamente se mudado para o condomínio em questão:

Percebia como a minha inserção no sistema hierárquico da sociedade brasileira levava-me constantemente a julgamentos apressados e preconceituosos, às vezes até por querer drasticamente repelir as noções anteriores, caindo em armadilhas inversas. Depois de ano e meio de residência no prédio, creio que consegui perceber alguns mecanismos que sustentavam a lógica das relações sociais internas e externas e também captar algo do estilo de vida e visão de mundo locais. Estou consciente de que se trata, no entanto, de uma interpretação e que por mais que tenha procurado reunir dados "verdadeiros" e "objetivos" sobre a vida daquele universo, a minha subjetividade está presente em todo o trabalho. Isso está claro para mim na medida em que volto constantemente a reexaminar a pesquisa e mesmo a revisar o local de investigação. Por outro lado, sendo um grupo que vive em minha cidade, conheço outras pessoas, inclusive cientistas sociais que o encontram, que também tem alguma familiaridade ou até fizeram pesquisas em contextos semelhantes. Desta forma a minha interpretação está sendo constantemente testada, revista e confrontada. O mesmo não se dá com muitos estudos de sociedades exóticas e distantes, pesquisadas por apenas um investigador, em que não houve oportunidade de maiores discussões ou polêmicas. Assim, a interpretação de um investigador fica sendo a versão existente sobre determinada cultura, não sendo exposta a certos questionamentos. $(1979$, p.43)

Além disso, em se tratando de uma pesquisa cujo foco é o ser humano, e cujo objetivo é apresentar outro modo de encarar a realidade escolar e social, o oferecimento de uma análise interpretativa me parece mais adequado do que a quantificação de quaisquer dados que, de qualquer modo, estreitariam meu foco e campo de visão, e me forçariam a deixar de contemplar aspectos que acredito serem relevantes para a pesquisa.

Nenhum método é capaz de compreender todas as variações sutis na experiência humana contínua. Consequentemente, os pesquisadores qualitativos empregam efetivamente uma ampla variedade de métodos interpretativos interligados, sempre em busca de melhores formas de tornar mais compreensíveis os mundos da experiência que estudam. (Denzin \& Lincoln, 2006, p.33) 
Importante também considerar que, enquanto nas ciências humanas o objeto é um "produtor de discurso", nas ciências naturais ele é mudo. Dessa maneira, considerando o sujeito como objeto de estudo das ciências humanas, e portanto do presente estudo, o conhecimento obtido a partir dele há que ser dialógico (Bakthin apud Sette, 2006, p.33).

De acordo com Peshkin, 1993 apud Richards, 2003, "Grande parte do que estudamos é verdadeiramente complexo, e envolve pessoas, eventos e situações caracterizadas por mais variáveis do que qualquer pessoa seja capaz de identificar, enxergar em uma relação, e lidar"19.

A pesquisa qualitativa no campo do ensino de língua estrangeira (e, arrisco dizer, no ensino em geral) é extremamente atrativa, pois o estudo mais detalhado de uma relação interpessoal, dentro de sala de aula, é uma realidade muito mais próxima do dia-a-dia dos profissionais de ensino.

Além disso, entendo que a Prática Exploratória alinha-se com Chizzotti ao defender que há uma impossibilidade inerente ao termo "pesquisa objetiva" nas ciências sociais, pois, nesse campo, toda e qualquer pesquisa será, por definição, 'sobre' pessoas e realizadas 'por' pessoas. Dessa maneira, creio ser ingênuo acreditar que a adoção da pesquisa quantitativa impeça a presença da subjetividade do pesquisador:

A posição social do autor da pesquisa, a onipotência descritiva do texto científico, a transcrição objetiva da realidade são postas em questão: o pesquisador está marcado pela realidade social, toda observação está possuída de uma teoria, o texto não escapa a uma posição no contexto político e a objetividade está delimitada pelo comprometimento do sujeito com sua realidade circundante. (Chizzotti, 2003, p.230)

Assume-se, então, a incapacidade de o pesquisador excluir sua individualidade a respeito do que é pesquisado, e, logo, a ingenuidade de se considerar qualquer pesquisa como sendo completamente objetiva.

Por isso, Allwright argumenta que:

\footnotetext{
${ }^{19}$ Tradução livre de "most of what we study is truly complex, relating to people, events, and situations characterized by more variables than anyone can manage to identify, see in a relationship, or operationalize."
} 
(...) ao estudarmos relatórios de pesquisa em nosso campo, provavelmente nos beneficiaremos mais das suas contribuições para o desenvolvimento de uma metodologia de pesquisa do que de qualquer outra descoberta a qual eles podem ter chegado. $\left(2000\right.$, p.5) ${ }^{20}$

Com isso, não se pretende desencorajar a pesquisa, muito pelo contrário. Acredita-se que a pesquisa deva ser uma prática ainda mais difundida, e feita regularmente, em cada sala de aula, por cada professor. Entretanto, o mais importante não está nas "conclusões" obtidas, mas no desenvolvimento de todo o trabalho de pesquisar.

\title{
3.2 \\ Como foi feita a pesquisa
}

Analisei o presente trabalho dentro da perspectiva qualitativa, e da tradição de "estudo de caso" (Richards, 2003), estabelecendo um diálogo entre as minhas observações em sala de aula, as entrevistas com a professora e os e-mails que trocamos, de modo a tentar assegurar uma gama maior de "janelas" abertas entre Walewska e eu, e, dessa maneira, uma interpretação mais abrangente do caso.

\begin{abstract}
A triangulação pode estabelecer ligações entre descobertas obtidas por diferentes fontes, ilustrá-las e torná-las mais compreensíveis; pode também conduzir a paradoxos, dando nova direção aos problemas a serem pesquisados. (Neves, 1996)
\end{abstract}

Durante o desenvolvimento da minha pesquisa, não fui mera observadora, mas envolvi-me diretamente na sala de aula estudada, contribuindo e interferindo diretamente naquela realidade. Ao longo das aulas, co-construí meus entendimentos conjuntamente com Walewska. Sendo assim, acredito ter realizado uma pesquisa híbrida, um estudo de caso exploratório.

\footnotetext{
${ }^{20}$ Tradução livre de: I wish to suggest that the above argument leads to the conclusion that when we are studying research reports in our field, we are likely to get more of lasting value from their contributions to the development of research method than from any substantive findings they may put forward. (2000, p.5)
} 
Como membro do grupo da Prática Exploratória do Rio de Janeiro, sempre me pareceram fascinantes, e ao mesmo tempo intrigantes, os relatos de Walewska em nossos encontros. A impressão que eu tinha era a de uma pessoa apaixonada pelo que faz.

Com o tempo, percebi que a admiração que eu nutria pela professora não era apenas minha, mas compartilhada pelo grupo da Prática Exploratória como um todo. Walewska é considerada um exemplo de professora exploratória, pelas suas histórias, seus comentários, e, talvez, principalmente, porque alguns alunos seus eventualmente compareciam às nossas reuniões para discutir conosco certas situações ou partilhar suas visões de mundo. A atitude da professora, que parece refletir até mesmo na maneira com a qual ela lida com todos à sua volta, ecoa por si só os Princípios e Proposições exploratórios tão discutidos por nós.

Considero importante dizer que, quando comecei a frequentar as reuniões da Prática Exploratória, apesar de concordar com a teoria, não conseguia, absolutamente, vislumbrar a possibilidade de adotar essa prática em sala de aula. Então, o meu olhar era, paradoxalmente, de empolgação, de admiração, e também de descrença. Ao mesmo tempo, Walewska, com suas histórias e seus alunos, me fazia imaginar se haveria algo mais. Ela me fazia querer saber, querer ver, querer entender. Além disso, ela sempre se mostrou um ser humano extremamente acessível, simples, humilde. Por tudo isso, surgiu a vontade de melhor entender essa sala de aula tão singular.

Encontramo-nos nos dias 21 de outubro e 20 de dezembro do ano de 2011. No primeiro dia, conversamos sobre seus entendimentos e vivência em sala de aula. Transcrevi essa conversa e enviei à professora por correio eletrônico. No encontro seguinte, busquei co-construir, conjuntamente com Walewska, nossos entendimentos. Busquei entender, com ajuda da própria professora, o porquê de ela ser apresentada / considerada uma professora exploratória, e o seu entendimento sobre a sua sala de aula.

Durante o período entre 26 de agosto de 2011 e 23 de novembro de 2011, também observei/participei de algumas de suas aulas, e escrevi um diário sobre elas, o qual mostrei, posteriormente, para a professora, que sentiu-se à vontade para adicionar suas impressões às minhas. Além disso, trocamos outros e-mails 
sobre as aulas na escola e também sobre outras questões, relacionadas à Prática Exploratória.

Inspiro-me nas palavras de Gilberto Velho sobre sua pesquisa em um condomínio de classe média baixa branca, comentado na subseção anterior, para realizar minha análise. A sala de aula exploratória em questão é uma realidade a ser trabalhada e analisada por mim, conjuntamente com Walewska, e, ainda assim, chegaremos a conclusões e aprendizados diversos. Uma sala de aula, com sua multiplicidade de personalidades, vivências, opiniões, olhares e questionamentos, torna qualquer padronização interpretativa improvável, quiçá impossível. Portanto, o meu objetivo final não é provar nada, mas oferecer a nossa análise, despertar a consciência.

Oferecendo o meu olhar interpretativo sobre essa professora e sua prática diária, gostaria de inspirar futuros leitores, alunos, professores, ou quaisquer outros profissionais que busquem melhorar sua qualidade de vida. Cada pessoa que ler essas páginas construirá um entendimento particular sobre o que está aqui escrito, e proporá seus próprios questionamentos. Não se trata de acreditar ou não, mas de conhecer. Citando Wolcott 1994:37, “a pesquisa é um meio de organizar o pensamento para alcançar um entendimento, e não um fim em si mesma"21.

\section{3 \\ Minha trajetória profissional}

Iniciei meus estudos de língua inglesa aos 11 anos, em um curso particular de línguas, no Rio de Janeiro. Na época, não me interessava pelas aulas, por considerá-las desestimulantes e, a pedido meu, minha mãe me retirou do curso.

Aos 13 anos, por pedido meu, minha mãe me matriculou em outra escola de línguas, a fim de mais uma vez iniciar meus estudos de inglês. Descobri-me então uma aluna extremamente interessada e participativa, e me formei por volta

\footnotetext{
${ }^{21}$ Tradução livre de: Research is a means of organizing our thoughts to reach understanding, not an end in itself.
} 
de 1999, aos 18 anos. Nessa época, já havia ingressado na Faculdade Nacional de Direito da Universidade Federal do Rio de Janeiro, seguindo a linha profissional dos meus familiares.

Como sempre gostei do idioma, ingressei no Teacher Training Course ${ }^{22}$ do curso de línguas no qual havia estudado, o qual cursei concomitantemente à faculdade. Ao receber meu diploma da graduação, recebi também meu diploma de conclusão desse curso.

Em 2003, último ano da faculdade de direito, comecei a lecionar em três diferentes cursos de idiomas, e ali me apaixonei pelo magistério. Em 2006, ingressei no curso de Letras Inglês-Português oferecido pela Universidade Estácio de Sá, no qual me graduei em 2009. Em 2007 e em 2011 viajei à Inglaterra para realizar cursos para professores, tendo obtido, em 2007, o diploma do CELTA Certificate of English Language Teaching for Adults ${ }^{23}$, fornecido pela Universidade de Cambridge.

No período de janeiro de 2006 a dezembro de 2009 lecionei inglês para crianças em um sistema de semi-imersão ${ }^{24}$. Os alunos tinham aulas de inglês de segunda a quinta, numa carga horária de $2 \mathrm{~h} 15$ diárias, totalizando assim 9h por semana de imersão à língua inglesa.

Essa experiência me marcou profundamente, sendo ela uma das principais responsáveis por eu estar onde hoje me encontro. Nesse colégio X, a prática de ensino da língua ocorria de uma maneira distinta da que costuma ocorrer em outras instituições de ensino nas quais eu já havia lecionado anteriormente. Apesar da carga horária extensa, eu possuía extrema liberdade didática e metodológica, sendo-me facultado inclusive escolher, junto à coordenação, o livro didático a ser adotado durante as aulas.

As aulas eram extremamente divertidas para mim, e para os alunos. Muitos responsáveis me perguntavam, extremamente desconfiados, se as crianças não cansavam do inglês, por estarem expostos de maneira tão intensa ao idioma

\footnotetext{
${ }^{22}$ Curso de Formação de Professores.

${ }^{23}$ Certificado de Ensino de Língua Inglesa para Adultos.

${ }^{24}$ Essas aulas não faziam parte do currículo escolar. Eram aulas extras oferecidas aos pais dos alunos, em horário anterior ao início do turno da tarde.
} 
por anos a fio (durante todo o tempo que ali estive, lecionei para a mesma turma, a qual se manteve relativamente estável, em torno de 10 alunos). A essas perguntas, eu respondia com um sorriso e um convite: Por que não pergunta a eles (os próprios alunos)?

Essa experiência me mostrou o quão prazerosa a aprendizagem pode ser. Claro que o número reduzido de alunos, o tempo de trabalho e a ausência de avaliação formal (por avaliação formal refiro-me às provas) ${ }^{25}$ são aspectos extremamente relevantes da situação em questão. Entretanto, o sucesso do projeto não pode ser atribuído somente a isso. Se as crianças não sentissem prazer em estar ali, e efetivamente aprendessem a língua inglesa (e orgulho-me em dizer que, aos 9 anos de idade, os meus alunos só falavam inglês em sala de aula), esse projeto estaria fadado ao fracasso. Felizmente, não foi o que aconteceu. Quando comecei a trabalhar neste colégio havia apenas uma turma e, hoje em dia, esse sistema se consolidou como um caso de sucesso nessa instituição, sendo oferecido em dois turnos, desde a Educação Infantil até o Fundamental II, num total de 7 turmas.

Desliguei-me do colégio ao iniciar o Mestrado em Estudos da Linguagem, da PUC-Rio. Nessa instituição, entrei em contato com a Prática Exploratória, que tem como um de seus core members e fundadores minha orientadora, Inés K. de Miller.

Assim que entrei no mestrado, comecei a refletir sobre a sala de aula tão especial que foi deixada para trás. Percebi o quão exploratórias eram aquelas aulas que eu, mesmo sem saber, lecionava. Eram aulas participativas, nas quais nenhum aluno era deixado de fora, todos eram ouvidos, e todos eram bem-vindos. Era com alegria que íamos todos à escola, alunos e professores, juntos. As mães me contavam como os filhos faziam questão de não faltar às aulas devido aos projetos em andamento, projetos esses que eram decididos conjuntamente, e aos quais todos se dedicavam com afinco.

\footnotetext{
${ }^{25} \mathrm{O}$ nosso sistema avaliativo consistia no preparo de portifolios e em relatórios bimestrais individuais. Não havia reprovações, por considerarmos que o ensino era sempre contínuo, independente da velocidade de aquisição da linguagem de cada indivíduo. Dessa maneira, a ansiedade em sala de aula era diminuída.
} 
Mas, sempre pensei ser ali uma situação única pois, como já foi dito, eu possuía uma carga horária privilegiada, poucos alunos, liberdade didática e metodológica, além da ausência de um sistema avaliativo formal. Apesar de a Prática Exploratória ser uma proposta extremamente inovadora e agradável, me parecia também intangível, pois a sociedade teria que mudar todo o sistema de ensino e, para isso, também o mercado deveria se adequar à nova safra de talentos produzida. Afinal, a sociedade capitalista prepara o material intelectual que o mercado de trabalho valoriza/consome.

Portanto, era com um misto de surpresa e incredulidade que, nas reuniões da Prática Exploratória, eu ouvia, dentre outros, os relatos de Walewska Braga, professora exploratória e também um dos core members do grupo, que leciona na Escola Municipal São Tomás de Aquino, no Leme. Ela descrevia uma sala de aula leve, com alunos interessados e participativos. E ela estava se referindo a alunos do município do Rio de Janeiro!

Nunca tendo lecionado no município, sempre ouvi falar e li a respeito das dificuldades encontradas nas escolas municipais. Realizar um trabalho satisfatório nesse ambiente me parecia, portanto, impossível. Assim, decidi conhecer melhor essa sala de aula tão inusitada e improvável, observando algumas aulas a fim de entender o que se passava de tão especial ali.

Irei retornar às minhas impressões mais adiante. Agora, apresentarei brevemente Walewska Braga, a professora em questão.

\section{4 \\ Quem é Walewska Braga}

Para essa subseção, hibridizando o texto, reproduzirei aqui, na íntegra, um e-mail que a própria Walewska enviou-me, em 13 de outubro de 2011:

Pensando sobre a minha vida profissional

Vanessa querida 
Bem, eu comecei estudando em um colégio em frente da minha casa e que era a minha casa: as professoras eram tias, minha mãe levava o lanche feito na hora e meus irmãos estudavam ali.

Depois fui para um gélido colégio de freiras alemãs (Santo Amaro) fazer o ginásio e detestei! A sala enorme, aquelas senhoras de preto, muita rigidez, disciplina, zero de alegria. Só gostava do lanche que o meu pai preparava cedinho, tinha sempre um drops ou um chocolate diamante negro. Comia escondido, passava para as colegas, tudo escondido...

E aí fui para o Colégio da Imaculada Conceição fazer o curso normal, porque eu queria se professora e ponto. O colégio era mais aberto, fiz amizades (minha comadre e eu nos conhecemos lá) e tudo foi mais light. As aulas eram bem chatas e vira e mexe eu matava as aulas.

Fora da escola eu aprendia piano na Escola Nacional de Música e não gostava. Não tinha talento e precisava me dedicar, só sensibilidade não bastava. Ficava sempre de $2^{a}$ época, tinha aulas particulares em janeiro e minhas férias só começavam em fevereiro (e as da família toda). Mas minha mãe achava importante uma moça aprender piano e eu não tinha saída. Até que muito mais tarde descobri Debussy e me encantei... Eu conseguia um som lindo e elogiado pelos professores, dei um concerto a 2 pianos: aquilo fazia sentido para mim (ia me formar, mas aí vi que não era aquilo mesmo e desisti no último ano! Hoje não sei tocar NADA!). Mas aprendi muito, tive provas orais, uma coisa fora do tempo, mas valeu, sempre vale!

Estudei inglês na Cultura: comecei aos 13 anos. Meu professor era um inglês que não falava português, o livro era de exercícios gramaticais e não tinha nem uma figura. Detestei, claro. Depois fiz Ibeu, um curso de conversação, já na faculdade. Adorei. Os colegas de sala eram mais velhos e eu me divertia muito.

E aí eu resolvi fazer faculdade, algumas colegas de sala estavam fazendo cursinho pré-vestibular. Por que não? Se ia ser professora... Entrei no curso quase no fim do ano e não sabia nada de nada (fiz normal!). Me lembro de ter ficado fascinada pelas aulas de literatura (o professor adorava o que fazia , as aulas eram ótimas) e aí decidi fazer licenciatura em português. Meu irmão já estudava engenharia na PUC e eu fiz vestibular para a PUC que era a faculdade mais perto de casa.

Passei no vestibular e tranquei a faculdade por 6 meses. Tinha a faculdade de música para me ocupar.

As aulas começaram e eu me encantei mesmo pelo pilotis. Matava muita aula (eu era bem ruinzinha, colava prá caramba). Mas a vida na faculdade naquele período de ditadura era intensa. Professores vigiados, alunos rebeldes. Poetas (Geraldinho Carneiro, Ana C., Cacaso). As matérias eletivas eram maravilhosas!!! A vida escolar era maravilhosa!!!

E um dia eu resolvi mudar; professora de português tem que corrigir redação! Tou fora! Resolvi fazer inglês. Menos trabalho...

Eu não gostava das aulas de pedagogia. Gostava das aulas de arte, de literatura e, dependendo do professor, da de inglês. Fui aluna da Hadara, que era muito exigente, mas de quem todos gostavam.

Minha prática de ensino foi na PUC e no Teresiano. O professor do Teresiano, Orlando, depois que dei a aula de literatura, disse que não sabia se me dava os parabéns ou os pêsames. Me deu 10 e disse que não tinha jeito; eu tinha mesmo 
de ser professora (mais tarde trabalhamos juntos no Stella Maris e eu fui professora dos 4 filhos dele.)

Tranquei outro semestre e fui passar uns meses em Harlow, England, perto da Epping Forest. O (então) marido de uma das minhas primas foi trabalhar lá, no fim do mundo, e ela queria alguém conhecido por perto. Fiz uns cursos de inglês em Londres (1 hora de metrô) e me diverti muito. Os alunos eram de todas as partes do mundo, o professor se atrapalhava, a aula era boba e aprendíamos mais nos lanches e passeios (vai ver que é por isso que gosto de levar os alunos para passear).

Voltei, desisti do piano, terminei a PUC.

Fiz concurso para o município e passei. Fui trabalhar em Guaratiba, na estrada do Mato Alto e minha companheira era a Beatriz Barreto, colega da PUC.

Bem, estamos em 1977 e eu comecei a trabalhar no Colégio Stella Maris. A Bia estava de licença maternidade e me indicou para substituí-la. As freiras gostaram do meu trabalho e me convidaram para dar aulas lá.

Em 85 eu fiz meu $2^{\circ}$ concurso para o município e mudei de escola, fui para a Praia da Brisa, quase em Sepetiba. Trabalhava 2 dias inteiros lá e os outros no Stella Maris.

Sempre gostei do trabalho no Município. Tinha liberdade para fazer o que quisesse e os alunos eram adoráveis. No Stella Maris a cobrança era grande, os alunos eram chatos, os pais mais chatos ainda. Mas eu trabalhava muito, no primário, na escola integral, ganhava bem. Os colegas eram ótimos. Júlia e eu nos conhecemos lá.

E eu ia a todos os seminários, eventos, encontros que apareciam. Semana do IBEU em julho, eu estava lá. Me inscrevia em tudo mesmo. E o que eu buscava? Uma receita, uma solução para os meus problemas, eu queria ser uma professora melhor. E quando eu usava na sala as novas técnicas ... NADA! Nada dava certo comigo! E vamos para outra conferência, outro livro, outra metodologia. Minha parceira de congresso era a Solange: sempre nos encontrávamos, mesmas buscas...

E aí (1997) eu recebo um convite para uma sessão de pôsteres da Prática Exploratória, na Cultura Inglesa da Tijuca.

E aí... Love at first sight!!!! Pois meus alunos estavam naqueles pôsteres; aquelas atividades eu fazia... Era aquilo, eu sabia!

E me inscrevi para o curso de PE. E meus alunos fizeram o pôster dos anjos ${ }^{26}$, que eu apresentei e depois eles fizeram outros pôsteres que apresentaram. E aí eu conheci a Bebel e a Inés e me tornei parte do grupo de PE.

Participei de muitos congressos, seminários, no Rio, no Brasil, no exterior. Em 2002 estivemos em Lancaster e aí conhecemos o Allwright. Fomos a Portugal, Espanha.

Em 2002 fiz o curso de especialização na PUC.

\footnotetext{
${ }^{26}$ Walewska enviou-me um e-mail explicando como foi feito esse pôster dos Angels, Caspers and Vampires, que foi mostrado diversas vezes em Encontros da Prática Exploratória e virou uma referência de uma APPE bem-sucedida. Esse e-mail encontra-se no Anexo III.
} 
Me aposentei do Stella Maris. E na matrícula antiga do município. Hoje só tenho uma matrícula. E a Prática Exploratória de inspiração e companhia.

E eu acho que é isso!

\section{5 A escola, as reuniões e os encontros}

Assisti e participei das aulas ministradas por Walewska Braga a duas turmas, de oitavo e nono anos, sempre às sextas-feiras, no turno da manhã, em uma escola municipal do Rio de Janeiro. A escola está situada na zona sul da cidade, próxima à praia, com um pátio interno e salas de aulas amplas e iluminadas.

Os alunos do oitavo ano (que eu chamei de Turma 1 nos anexos) tinham uma média de 13/14 anos, e os alunos do nono ano (Turma 2), 14/15 anos. Cada turma tinha uma média de 35 a 40 alunos. Observando os alunos, percebi nitidamente um ambiente de camaradagem entre eles. Naturalmente, eles organizavam-se em grupos, provavelmente por afinidade, mas não percebi hostilidade entre os grupos, em nenhuma das turmas. A turma do oitavo ano parecia mais participativa, no sentido de que a maioria dos alunos era mais atuante nas aulas, dando opiniões e oferecendo-se a ajudar a professora. A turma do nono ano já se comportava de maneira mais relaxada, apesar de haver um grupo mais participativo e ativo. Os funcionários da escola aos quais tive acesso, dos inspetores às secretárias da Direção, sempre foram muito atenciosos e gentis.

Por ser uma escola municipal, ela recebe alunos provenientes de família de baixa renda. As cadeiras e os murais da escola, por exemplo, são um pouco mal conservados. Entretanto, não notei nada que pudesse impactar fortemente, a meu ver, o aprendizado dos alunos.

Durante a minha presença na escola, fiz a minha primeira entrevista com Walewska, no corredor. A segunda entrevista foi feita na área externa da PUC, por ocasião de uma reunião do grupo da Prática Exploratória. Encontram-nos um 
pouco antes do horário para conversarmos a respeito das minhas impressões a respeito da primeira conversa.

\section{6 \\ O arcabouço teórico-metodológico da Prática Exploratória na Pesquisa}

Apesar de, na seção anterior, ter apresentado as ideias principais da Prática Exploratória, seus princípios e proposições, acho importante revisitarmos o conceito de pesquisa de acordo com a Prática Exploratória, já que tal conceito será de extrema relevância para esse trabalho.

Na pesquisa do praticante (practitioner research, cf Allwright \& Hanks, 2009) busca-se construir uma parceria entre membros de um grupo, de maneira que todos trabalhem conjuntamente, evitando assim o tipo de pesquisa parasítica na qual o pesquisador entra em uma sala de aula para observações e depois retirase sem propiciar ao professor ou aos alunos nenhum tipo de feedback sobre o que ele/a observou (Allwright, 2009, p.138).

Dentro desse conceito encaixam-se vários tipos de parceria, dentre elas a que está presente nesse estudo, uma parceria entre estudante de mestrado e professora exploratória, ambas membros do grupo da Prática Exploratória do Rio de Janeiro. Envolvida nessa parceria exploratória, procurei observar-vivenciar outras pesquisas sendo desenvolvidas (uma pesquisa dentro de outra), entre a professora e seus alunos, e a busca de entendimentos vários sobre a vida em sala de aula. Digo vivenciar, pois, em minhas observações, não procurei comportar-me como uma observadora 'invisível", pois acredito que, por mais que tentasse passar despercebida, a minha simples presença no ambiente já seria o suficiente para causar desconforto, estranhamento, e mesmo alterar o modo como os alunos e a própria professora se comportam. Portanto, a convite de Walewska, prontamente concordei em participar das atividades e auxiliava os alunos, de maneira que tornei-me parte integrante daquele contexto. E, dessa maneira mais próxima, os alunos entenderam que eu era apenas uma estudante ávida por conhecê-los, e não 
algum tipo de ameaça externa ou avaliativa. Não acredito que esse tipo de postura invalide a minha pesquisa ou minhas conclusões, muito pelo contrário; vejo que agir de maneira contrária significaria ir de encontro com a filosofia exploratória que busco, acredito e utilizo nessa dissertação. A esse respeito, cito Allwright, quando fala sobre o Princípio 3 da Prática Exploratória, "envolver todos no trabalho":

Já que a vida na sala de aula é necessariamente social, então a conduta de qualquer pesquisador praticante será também uma questão social. Então, por exemplo, aprendizes estarão envolvidos não como objetos de pesquisa mas como colegas participantes e, portanto, co-pesquisadores. $(2003 \mathrm{~b}, \text { p. } 129)^{27}$

A Prática Exploratória acredita na importância da pesquisa como uma atividade diária e inclusiva. Apesar de respeitarmos as pesquisas tradicionais que buscam generalizações, entendemos que professores e alunos precisam de entendimentos imediatos para lidar com alguma situação particular que eles estão vivenciando, e torna-se ingênuo acreditar que essas pessoas podem esperar uma pesquisa ser concluída e publicada para então eles terem acesso às conclusões de um pesquisador e decidirem se isso é aplicável a eles ou não (Allwright, 2009, p.143); visto que, até os resultados serem publicados e os alunos ou professores terem acesso a eles, o ano letivo já terminou e a situação a ser entendida já mudou.

A Prática Exploratória advoga uma pesquisa qualitativa, cotidiana, praticada em conjunto, na qual todos são pesquisadores e buscam um melhor entendimento de situações rotineiras que, por alguma razão, os intrigam (puzzles). A importância do pesquisar como uma prática social necessária e imediata especialmente no que diz respeito à sala de aula, cuja configuração muda semestralmente ou anualmente (ao menos no Brasil), de modo a melhorar a vida do professor e do aluno é latente, a meu ver.

\footnotetext{
${ }^{27}$ Tradução livre de "Since life in the language classroom is necessarily social, then the conduct of any practitioner researcher carried out there will also be a social matter. So, for example, learners will be involved not as objects of research but as fellow participants, and therefore as coresearchers".
} 
Cresce, porém, a consciência e o compromisso de que a pesquisa é uma prática válida e necessária na construção solidária da vida social, e os pesquisadores que optaram pela pesquisa qualitativa, ao se decidirem pela descoberta de novas vias investigativas, não pretenderam, nem pretendem furtar-se ao rigor e à objetividade, mas reconhecem que a experiência humana não pode ser confinada aos métodos nomotéticos de analisá-la e descrevê-la. (Chizzotti, 2003, p.232)

E, desse modo exploratório, em que as relações se expandem como uma teia de aranha, a pesquisa foi sendo desenvolvida, de acordo com os Princípios da Prática Exploratória.

\section{7 Instrumental Microanalítico}

O modelo de tomada de turnos idealizado por Sacks, Schegloff e Jefferson (1974 apud West \& Zimmerman, 1978) serviu de base para a análise. Para a Análise da Conversa (doravante AC), a melhor compreensão da tomada de turnos em uma interação é importante para que se desenvolva um melhor entendimento acerca de outros diversos momentos interacionais macro. A AC demonstrou a importância de se compreender os detalhes das interações que ocorrem diariamente entre os indivíduos para se chegar a um entendimento mais completo de nossa sociedade, seus valores e comportamentos (Antaki \& Díaz, 2004).

Através dessas análises, descobriu-se que há uma estrutura na interação oral, uma ordem que, a princípio, é mantida. Nota-se facilmente tal organização através da percepção de pares adjacentes na interação. Toda elocução possui, a princípio, seu par adjacente ${ }^{28}$. A falta deste, ou a hesitação do interagente ao responder, por exemplo, todos são exemplos de comportamentos passíveis de análise.

\footnotetext{
${ }^{28}$ Par adjacente foi “(...) (um termo inventado no final da década de 1960 pelo fundador da AC, Harvey Sacks). Isso é simplesmente um par de enunciados que 'vão juntos' como uma pergunta e sua resposta, uma chamada e sua resposta, uma saudação e outra saudação em retorno. Esses são elementos bastante comuns de nossa linguagem e uma das coisas que fazem é deixar claro que o atual falante acabou de falar, e que, portanto, é a vez de alguma outra pessoa. Fazer uma pergunta significa que alguém tem que responder." (ANTAKI \& DÍAZ, 2004)
} 
Considerando-se que o padrão da conversa se dá em turnos, ou seja, que o falante apenas iniciará seu turno após o outro falante terminar o seu; a fala simultânea de dois ou mais falantes, interferindo um no turno dos outros, pode significar algum tipo de problema interacional. Entretanto, a AC não trabalha com o conceito de interrupções, que são definidas como violações no turno de fala dos falantes; mas com o conceito de sobreposições. Segundo Tannen (2010, p.74):

Afirmar que uma interrupção é um sinal de dominação parte do princípio de que a conversa é uma atividade na qual somente um participante fala de cada vez, mas isso reflete mais uma posição ideológica do que as práticas reais em si.

Entende-se que os falantes, a princípio, precisam esperar o término de um turno para começar seu próprio turno. Mas, ao mesmo tempo, o falante procura minimizar os espaços temporais entre os turnos de fala, de maneira a demonstrar seu interesse e atenção em relação ao que está sendo dito, e também precisa evitar falas simultâneas. Com tudo isso, é um pouco frequente a ocorrência de pequenos períodos de falas simultâneas, justamente nos locais de possível transição de turnos. A AC chama tal fenômeno de simultaneidade e não o entende como violações em turnos de fala. Em última análise tais sobreposições possuem uma função facilitadora, justamente por demonstrarem o engajamento do interlocutor na conversa, e não são, portanto, consideradas negativas. Para Tannen (2010, p.77),

(...) falantes de alto envolvimento não se importam com sobreposição de vozes. Esses falantes cedem a uma intrusão somente se quiserem; se não quiserem, adiam a resposta ou ignoram a interrupção completamente. (...) Outra razão por que essas sobreposições são cooperativas é que elas não mudam o tópico, mas o elaboram.

Já as interrupções são consideradas violações do direito do falante corrente em continuar o seu turno e desorganizam a construção dos assuntos em desenvolvimento. Elas não possuem, de maneira alguma, o propósito facilitador da simultaneidade descrita acima, e são por vezes consideradas uma espécie de bullying conversacional (Tannen, 2010).

Nos trechos analisados discutir-se-á se há interrupções ou sobreposições cooperativas entre os turnos dos falantes, e, juntamente com a análise das 
narrativas como estratégia de envolvimento interacional, pretende-se observar pontos de convergência entre Walewska e eu, mostrando, assim, meu processo de convencimento da viabilidade da adoção da Prática Exploratória em uma sala de aula real (em oposição a uma sala de aula ideal), e também o meu processo de entendimento e compreensão da Prática como uma filosofia de vida.

Com relação à interpretação do discurso de cada interlocutor, participante da conversa, é mister observar que cada um deles ocupa um papel social específico, e isso significa, também, que, ao falar, muitas vezes, verbalizam crenças de um grupo, e não posições exclusivas. São muitas vozes que encontramse presentes no discurso proferido, como já foi discutido nesse trabalho (p. 24). Nas palavras de Goffman:

(...) não se lida tanto com um corpo ou mente, mas, sim, com uma pessoa que ocupa algum papel ou identidade social específica, alguma qualificação especial como integrante de um grupo, posto, categoria, relação, associação ou qualquer fonte de auto-identificação socialmente referenciada. Muitas vezes, isso significará que o indivíduo fala, explícita ou implicitamente, em nome de um "nós", não de um "eu” (...) (p.134)

Ao longo da pesquisa, procurei relacionar o discurso gerado por Walewska na entrevista, na conversa e nos e-mails, com as Proposições e Princípios da Prática Exploratória abordados no capítulo anterior. Procurei identificar ecos da Prática Exploratória em todos os trechos, de maneira a entender a integração da Prática Exploratória na vida cotidiana de Walewska. Assim, acredito que as Proposições e Princípios da Prática Exploratória também constituem, em si mesmos, um instrumental de análise nesse trabalho. 


\section{Análise}

Nesse capítulo, analisarei trechos selecionados de nossa interação, buscando as identidades projetadas e os enquadres e padrões de tomadas de turno, e procurarei relacioná-los aos Princípios e Proposições da Prática Exploratória.

\section{1}

\section{A entrevista e a conversa}

Este trabalho se propõe a analisar trechos de uma entrevista e uma conversa, ambas gravadas por mim, que sou participante das interações, além de analista do discurso. Ainda que as transcrições das interações sejam meus dados primários, ultilizei anotações pessoais das aulas que observei, bem como e-mails trocados entre Walewska e eu durante o período de observação de aulas, e um artigo retirado de um jornal online (todos sinalizados em notas de rodapé ou no corpo do texto), de modo a fazer com que os dados gerados dialoguem entre si, complementando-se.

Esta análise tem como foco as interações transcritas, ou seja, procura-se centrar na minha observação e interpretação das práticas interacionais questionadas.

Chamei a primeira interação de entrevista, pois nota-se uma maior preocupação minha em evitar interromper Walewska, permitindo que mantenha o piso conversacional pelo tempo necessário, muito embora houvesse momentos em que eu me comportasse mais como colega do que como entrevistadora. De acordo com Georgakopoulou (p.237): 
O protótipo do entrevistador tende a evitar interrupções ou desafios durante a narração de histórias e abstém-se de comunicar suas próprias experiências, opiniões e sentimentos; o protótipo do entrevistado, por outro lado, conta a história para ouvidos atentos, preenche as lacunas, e cria os enquadres faltantes de referência mútua.

Já na segunda interação, por verificar-se um maior número de interrupções e sobreposições, mostrando que nos comportamos mais como colegas do que como entrevistadora e entrevistada, decidi chamá-la de conversa.

As interações foram divididas em trechos, que estão numerados, de maneira a facilitar não só a análise, mas também a consulta dos leitores à integra das transcrições. Como por vezes o turno da conversa é muito longo, os trechos analisados foram subdivididos em fragmentos. A transcrição das conversas na íntegra está nos anexos I e II.

A transcrição de nossos encontros, ocorridos em 21 de outubro de 2011 e 20 de dezembro de 2011, será analisada em trechos selecionados, de maneira a ilustrar como as falas dialogam entre si. Os trechos do primeiro encontro, ao qual chamei de entrevista, foram analisados em ordem cronológica, e funcionaram como um fio condutor. Os trechos do segundo encontro, ao qual chamei de conversa, os e-mails e o diário foram trazidos para enriquecer a análise do trecho, e, por isso, serão encontrados sempre vinculados a um trecho da primeira conversa.

No primeiro trecho a ser estudado, Walewska sabia tratar-se de uma entrevista informal para uma dissertação de mestrado. Portanto, depois da minha pergunta, Walewska começa a respondê-la, e eu, Vanessa me posiciono como ouvinte, sem interrompê-la. Ali verificam-se duas identidades sendo projetadas: eu, como mestranda e pesquisadora, e a Walewska, como professora exploratória, que está ciente do objetivo da ouvinte e procura colaborar respondendo à primeira pergunta: 


\section{Quadro 1- Entrevista, Trecho 1}

\begin{tabular}{|c|c|c|}
\hline $\begin{array}{l}1 \\
2\end{array}$ & Vanessa & $\begin{array}{l}\text { A primeira é o que te levou à prática exploratória, assim, como } \\
\text { você conheceu }\end{array}$ \\
\hline 3 & Waleswka & É:: \\
\hline 4 & Vanessa & como, $[\downarrow$ como é que foi isso $\downarrow]$ \\
\hline $\begin{array}{l}5 \\
6 \\
7 \\
8 \\
9 \\
10 \\
11 \\
12 \\
13 \\
14 \\
15 \\
16 \\
17 \\
18 \\
19 \\
20 \\
21 \\
22 \\
23 \\
24 \\
25 \\
26 \\
27 \\
28 \\
29 \\
30 \\
31 \\
32 \\
\end{array}$ & Waleswka & $\begin{array}{l}\text { [Eu, eu recebi] um convite para uma sessão de pôsteres } \\
\text { de prática exploratória...pelo município. E eu sempre fiquei, né, } \\
\text { buscando uma receita, uma solução para as minhas aulas. Eu } \\
\text { tinha assim uma grande insatisfação com o que eu fazia, com o } \\
\text { que eu sentia. > Não era aquilo<. Por mais que eu me esforçasse, } \\
\text { >não era aquilo<, faltava alguma coisa. E o que eu vejo hoje que } \\
\text { faltava era essa parte humana que eu não conseguia, porque a } \\
\text { gente tá em inglês, e então, a matéria inglês, você fala inglês, é } \\
\text { uma outra língua, não tem uma coisa, ou não tinha, na época, né, } \\
\text { ou no jeito que eu trabalhava, não tinha uma aproximação. Eu } \\
\text { me lembro, assim, de ficar babando porque professores de } \\
\text { ciências, de português, eles eram muito próximos dos alunos. } \\
\text { Eles conheciam muito. E eu, queria, mas não... >tinha uma } \\
\text { barreira, eu tinha que falar inglês, eles não falavam português, } \\
\text { aquela doidera<...ninguém ficava junto, era um trabalho assim, } \\
\text { sabe...o máximo era o, o...qual é a diferença, eu me lembro isso, } \\
\text { era uma >coisa dificílima<. Qual a dife, é, marque na na frase a } \\
\text { diferença entre o present perfect e o simple past tense, e isso } \\
\text { eram coisas assim...não podia ser aquilo, não podia, entendeu? } \\
\text { Era muita coisa e não ia. Quando eu vi... essa sessão de } \\
\text { pôsteres...na Cultura Inglesa da Tijuca, eu vi...os alunos, a fala } \\
\text { dos alunos, exercícios que nós fazíamos de simple present tense, } \\
\text { e aquilo tinha uma outra história, tinha um envolvimento em } \\
\text { inglês. E aí eu achei muito legal, comecei, foi oferecido um } \\
\text { curso, pelo...não sei, o grupo de...não sei mais como se chama, } \\
\text { seria uma APLIERJ mais ou menos hoje, de professores de } \\
\text { inglês, e, a, eram reuniões, se não me engano quinzenais e du } \\
\text { durante o ano 98 eu fui a essas reuniões. (...) }\end{array}$ \\
\hline
\end{tabular}

Analisando-se o trecho onde Walewska explica sua relação com a Prática Exploratória, as linhas 8, 9 e 10 mostram a insatisfação de Walewska com sua prática profissional na época, que é reforçada pela repetição da frase "não era aquilo". Ela alega saber que "faltava alguma coisa", sem saber, entretanto, o que era. Nesse ponto, ela projeta sua identidade de professora de inglês em busca de maior satisfação profissional, antes de conhecer a Prática Exploratória. Na linha 11 ela diz que "hoje sabe que faltava uma parte humana", projetando assim a sua identidade de professora exploratória atual. Dessa maneira, Walewska projeta sua 
identidade de "antes" e "depois" de conhecer e se identificar com a Prática Exploratória.

No início dessa conversa vê-se que há sobreposição de turnos nas linhas 4 e 5. É interessante notar a frequência desse tipo de sobreposição entre os turnos, durante a conversa. Acredito que tais sobreposições não configuram uma violação no turno de fala dos falantes, pois ocorre, em um ponto muito próximo ao local de transição de turno. Interpreto essas sobreposições como fenômenos interacionais entre dois falantes de alto envolvimento engajados na discussão proposta. Tal exemplo ilustra a função facilitadora que pode ser atribuída ao conceito de simultaneidade (Tannen, 2010)

\section{Quadro 2 - Entrevista, Trecho 1}

\begin{tabular}{|c|c|c|}
\hline $\begin{array}{l}32 \\
33 \\
34 \\
35 \\
36 \\
37 \\
38 \\
39 \\
40 \\
41 \\
42 \\
43 \\
44 \\
45 \\
46 \\
47 \\
48 \\
\end{array}$ & Waleswka & $\begin{array}{l}\text { E aí era um trabalho assim, } \\
\text { muitas vezes eu não entendia onde é que aquilo ia dar, } \\
\text { tinha assim muito a cara de Bebel e Inés, né, do jogar que eu } \\
\text { até gosto muito, essa, essa história, até faço um pouco com os } \\
\text { meus alunos, deixar assim no ar, mas eu acho isso muito } \\
\text { interessante, né...toma...e não cobra. Toma, ó, pra próxima } \\
\text { aula isso, nem sempre a gente discutia aqueles textos, então no } \\
\text { início eu era muito perdida. Mas me encantava o modo que } \\
\text { eles...me ouviam. E, eu fui também ouvindo o meu aluno, } \\
\text { então eu era ouvida e eu aprendi a ouvir. Então foi mais ou } \\
\text { menos por aí. Nada era impossível, eu não era cobrada. Eu } \\
\text { trazia, né, nas nas reuniões a gente >falava, discutia e tal<, e aí } \\
\text { eu dava...falava assim, olha, >na minha sala aconteceu<, e } \\
\text { aquilo >era discutido, era debatido<. Existia uma } \\
\uparrow \text { importância no que eu falava. Eu tava sendo ouvida e nunca } \\
\text { tinha sido ouvida, né, eu era ouvida, assim, pra dizer, [o aluno } \\
\text { melhorou? Tirou no...?] }\end{array}$ \\
\hline 49 & Vanessa & [Uhum, uhum] \\
\hline
\end{tabular}

Nas linhas 40 a 46 Walewska narra como, nos encontros do "curso" da Prática Exploratória, os participantes ouviam os seus relatos de maneira especial: ali não se queria saber de números ou resultados, todos pareciam verdadeiramente engajados em compreender suas inseguranças e entender sua prática. A importância que Walewska dá ao fato de ouvir e ser ouvida é enfatizada através das quatro repetições do verbo, nas linhas 40 e 41 . A professora também afirma que "não era cobrada", o que contribuía, sem dúvida, para um ambiente mais 
relaxado, de maior confiança e, consequentemente, de maior apoio mútuo. Tal relato ilustra o Princípio 2 da Prática Exploratória: “Trabalhar para entender a vida em sala de aula ou em outros contextos profissionais", visto que havia ali um grupo em um esforço genuíno para entender. O Princípio 1, "Priorizar a qualidade de vida" também está subjacente nesse relato, através do trabalho para o entendimento e o ambiente de camaradagem das reuniões. Desse modo, a professora também projeta sua identidade de professora em transformação, ao narrar como se identificou com a filosofia da Prática Exploratória.

No trecho final dessa conversa vê-se que há sobreposição de turnos em duas ocasiões. A primeira delas ocorre ao final do turno de Walewska, quando eu emito um som (back-channel ${ }^{29}$ ) que mostra que entendo o que foi dito (1. 48 e 49). Com esse som procurei mostrar à Walewska que, após um longo turno de fala, eu continuo uma ouvinte atenta e interessada no que ela tem a me dizer.

Walewska prossegue sua fala e na linha 51 eu novamente inicio mais um turno. Quando ela disse que não era ouvida, eu quis saber em que sentido ela afirmava isso. De qualquer modo, ela já havia iniciado a explicação desse meu questionamento na linha 40, e terminou seu raciocínio nas linhas 52 a 55. De novo, essas sobreposições ocorrem para reafirmar o engajamento da ouvinte, após um longo turno de fala de Walewska. Essa inerpretação ecoa Tannen (2010, p.74), quando a autora diz que “ (...) não é a interrupção que constitui a dominação, mas aquilo que os falantes estão tentando fazer ao falarem uns com os outros".

\footnotetext{
${ }^{29}$ http://www.cs.utep.edu/nigel/bc/
} 
Quadro 3- Entrevista, Trecho 2

\begin{tabular}{|c|c|c|}
\hline 50 & Waleswka & Por que que esse aluno? O que que ele fez? Mas não prá saber \\
\hline 51 & Vanessa & [LÉ mesmo? Você...? ah, entendi.] \\
\hline 52 & Walewska & [o que estava acontecendo] na vida da sala de aula. Então não \\
\hline 53 & & tinha assim um certo e um errado. Tinha coisas que iam \\
\hline 54 & & acontecendo que a gente queria trabalhar, a gente queria \\
\hline 55 & & entender, né? Claro que isso foi construído, né, também tem \\
\hline 56 & & toda essa história super interessante de todos nós construírmos \\
\hline 57 & & a prática exploratória. Então ela pode ir pra cá, ou pra lá, \\
\hline 58 & & ela...se ${ }^{\circ}$ encaixa $^{\circ}$ no $>$ meu modo de viver, no meu modo de \\
\hline 59 & & ensinar, que tá junto do meu modo de viver, no seu, na na \\
\hline 60 & & filosofia< então vai levando, assim, né, vai tecendo essas coisas \\
\hline 61 & & e eu acho muito interessante. Mas foi exatamente isso, um \\
\hline 62 & & convite, como tantos que eu recebi. Como tanta tantos \\
\hline 63 & & $\overline{\text { seminários e eventos que eu fui. Né, eu e Solange, por }}$ \\
\hline 64 & & exemplo, >que você não conheceu porque ela agora é avó duas \\
\hline 65 & & vezes então esse ano ela tá complicada $<$, mas eu e Solange \\
\hline 66 & & nos conhecemos de conferência, de eventos, ela tava lá... oi ! A \\
\hline 67 & & gente nem sabia, mas, é curso de a Grande Escola de Inglês ${ }^{30}$ \\
\hline 68 & & oferece um curso para os professores do município. Nós \\
\hline 69 & & tavamos lá, e a gente chegava e tavam ensinando do, \\
\hline 70 & & did...pera lá, né, meu senhor? \\
\hline
\end{tabular}

Nas linhas 52 a 61, Walewska se projeta como uma profissional reflexiva, que busca e deseja entender suas questões e solucionar seus dilemas. É o professor responsável pelo próprio desenvolvimento profissional (o que também é explicitado nas linhas 65 e 66, quando Walewska afirma estar sempre indo a conferências e eventos, buscando sempre uma maneira de "melhorar" suas aulas e aprimorar-se como professora). Ao repetir a palavra "querer" com ênfase (1.54), ela reforça essa vontade de entender.

$\mathrm{Na}$ linha 56, ao enfatizar que "todos" construíram a Prática Exploratória, ela foca na agentividade e na coletividade do grupo da Prática Exploratória como profissionais de apoio mútuo. Todos se ouvem, querem trabalhar juntos, querem entender, e todos juntos constroem a Prática Exploratória, diariamente.

Ao final da conversa, é interessante perceber a indignação de Walewska com relação aos cursos oferecidos para os professores do município. Nas linhas 69 e 70 nota-se uma crítica à ideia pré-concebida que se tem a respeito do

\footnotetext{
${ }^{30} \mathrm{O}$ nome é fictício.
} 
professor de inglês do município. Walewska faz a crítica em tom jocoso; entretanto, a piada feita pela professora não tem como objetivo principal o humor, mas a reflexão, como nota-se no próximo trecho:

\section{Quadro 4- Entrevista, Trecho 3}

\begin{tabular}{|l|l|l|}
\hline 72 & Walewska & Risos. É interessante porque isso, né? Esse imaginário, 个quem \\
73 & & é o professor do município, ele sabe, ele não sabe, ele não \\
74 & & fala... \\
\hline
\end{tabular}

Passemos ao próximo trecho selecionado, no qual discutimos a questão da prática como uma filosofia, como uma mudança de paradigmas:

\section{Quadro 5- Entrevista, Trecho 4}

\begin{tabular}{|l|l|l|}
\hline 85 & Vanessa & E, o que, o que que você define, o que que você entende por \\
86 & & prática exploratória? É fácil você definir, como é que... \\
\hline 87 & Walewska & 个Não, a prática exploratória é um modo de...viver, uma \\
88 & & filosofia, oque vai muito pelo coração, pelo entendimento, pelo \\
89 & & $\underline{\text { social, pelo humano. É sempre priorizar o outro, numa época de }}$ \\
90 & & competição, de...resultados... Então talvez seja assim uma coisa, \\
91 & & e é mesmo uma coisa muito contestada, né, porque...eu não me \\
92 & & preocupo com resultado...claro que eu quero que os meus \\
93 & & alunos...sejam bem sucedidos, mas eu vejo também que eles tem \\
94 & & uma vida pela frente então não é exatamente no ano de 2011, no \\
95 & & mês de outubro, que eu tenho que ficar preocupada com o índice \\
96 & & o INDEB, sei lá, \\
\hline 97 & Vanessa & [Até porque] \\
\hline 98 & Walewska & [ADEB...] \\
\hline
\end{tabular}

Na linha 97, inicio uma interrupção que é ignorada por Walewska (linha 98), gerando aí uma sobreposição de turnos, que mostra as duas participantes da conversa como falantes de alto envolvimento, cujas sobreposições elaboram o tópico (Tannen, 2010).

Nas linhas 87 a 89 da Entrevista, Trecho 4, Walewska diz que a Prática Exploratória é uma filosofia, e enfatiza as palavras "coração", "entendimento", "social", "humano", e "outro", o que sugere a importância do sentimento, do 
entendimento, e da comunidade para a professora. Ao interpretar as suas palavras, entendo que elas se aproximam mais do conceito oriental de filosofia, o que, de certa maneira, está de acordo com os valores que a professora transparece em seu discurso.

Nas linhas 92 e 93 da Entrevista, da mesma conversa, quando a professora afirma que, apesar de desejar que seus alunos sejam bem sucedidos, não acredita que para que isso ocorra seja necessário buscar os resultados estabelecidos por outro órgão externo à sala de aula, também ouço o eco da Proposição 5 da Prática Exploratória, pois a professora acredita que os alunos são praticantes do próprio aprendizado, sendo desnecessário submetê-los a pressão e padrões avaliativos externos.

O interessante nessa passagem da Entrevista é a afirmação de Walewska quando diz que a Prática Exploratória é "sempre priorizar o outro, numa época de competição, de resultados.” (linhas 89-90). Em nosso encontro posterior ${ }^{31}$, denominado conversa, refletimos a respeito dessa afirmação:

\section{Quadro 6- Conversa, Trecho 2}

\begin{tabular}{|c|c|c|}
\hline $\begin{array}{l}72 \\
73\end{array}$ & Vanessa & $\begin{array}{l}\text { é..cê colocou "é sempre priorizar o outro, numa época de } \\
\text { competição, de resultados", cê viu? }\end{array}$ \\
\hline 74 & Walewska & Uhum \\
\hline $\begin{array}{l}75 \\
76 \\
77\end{array}$ & Vanessa & $\begin{array}{l}\text { Eu tava pensando sobre...essa informação...e aí se você for } \\
\text { pensar bem, o priorizar...o outro não é um conceito da nossa } \\
\text { sociedade }\end{array}$ \\
\hline 78 & Walewska & [Exato] \\
\hline $\begin{array}{l}79 \\
80 \\
81 \\
82 \\
83\end{array}$ & Vanessa & $\begin{array}{l}\text { [né?] A nossa sociedade ela é extremamente individualista. A } \\
\text { gente trabalha e a gente molda os indivíduos desde crianças a } \\
\text { serem individualistas, você não prioriza o outro, pensa em } \\
\text { você, pensa em você sempre, cê tem que pensar em você, [não } \\
\text { é?] }\end{array}$ \\
\hline 84 & Walewska & $\begin{array}{lc} & {[e ́ . . .]} \\
\end{array}$ \\
\hline 85 & Vanessa & O que que você quer...[é sempre assim!] \\
\hline $\begin{array}{l}86 \\
87 \\
88 \\
89 \\
90 \\
91 \\
92\end{array}$ & Walewska & $\begin{array}{l}\text { [e você estimula] a competição. Se você } \\
\text { estimula a competição você olha o outro como um obstáculo a } \\
\text { superar...né? Você não vai aprender com o outro, se eu tenho } \\
\text { que saber mais que o outro...cê não vai, cê vai deixar isso de } \\
\text { lado. Então é nesse sentido sim...e.:.:......a até é engraçado } \\
\text { porque a gente fala assim, como a prática exploratória é é } \\
\text { transgressora, se o que ela fala é de união, é de aprender com o }\end{array}$ \\
\hline
\end{tabular}

\footnotetext{
${ }^{31}$ Trechos do nosso segundo encontro estão transcritos no ANEXO II
} 


\begin{tabular}{|c|c|c|}
\hline $\begin{array}{l}93 \\
94 \\
95 \\
96 \\
97\end{array}$ & & $\begin{array}{l}\text { outro, é de ter qualidade de vida...não é isso que se busca? } \\
\text { Mas essa transgressão é nesse sentido. É:: a soci a nossa } \\
\text { sociedade, né, a sociedade capitalista, mas, mas enfim, é:: a } \\
\text { nossa sociedade estimula isso, competição, nós temos na } \\
\text { escola, a prova, né, sim, e você [vê mesmo] }\end{array}$ \\
\hline 98 & Vanessa & {$[$ Nós temos na vida $]$} \\
\hline $\begin{array}{l}99- \\
118\end{array}$ & & $(\ldots)$ \\
\hline $\begin{array}{l}119 \\
120 \\
121 \\
122\end{array}$ & Vanessa & $\begin{array}{l}\text { [Porque como] é um soci...co como é um conceito que é } \\
\text { completamente, que que é é um conceito muito oriental, não é } \\
\text { um >conceito da sociedade ocidental }<\downarrow \text {, eu pe - é isso mesmo } \\
\text { que ela quer dizer? É priorizar mesmo? }\end{array}$ \\
\hline $\begin{array}{l}123 \\
124\end{array}$ & Vanessa & $\begin{array}{l}\text { [Porque] é [> uma coisa realmente<], não é do con[ceito da } \\
\text { sociedade... }\end{array}$ \\
\hline $\begin{array}{l}125 \\
126 \\
127\end{array}$ & Walewska & $\begin{array}{l}\text { [É::] } \text { [Priorizar] } \\
\text { assim, eu tenho que ter respeito, e isso realmente...é } \\
\text { meio...oriental, [né?] }\end{array}$ \\
\hline 128 & Vanessa & [Uhum] \\
\hline
\end{tabular}

Walewska concorda com a minha opinião de que o priorizar o outro não é um conceito da sociedade ocidental, que é extremamente competitiva, talvez reflexo do nosso sistema econômico capitalista. Walewska reconhece essa característica da sociedade capitalista, que estimula sempre a competitividade, que é mostrada mesmo através do sistema avaliativo escolar tradicional (provas). Ela entende o priorizar como ter respeito pelo outro, ouvir o outro, e construir algo em conjunto para que a qualidade de vida de todos melhore (Princípio 1). A qualidade de vida almejada (Princípio 1) não vem da competitividade, mas da cooperação, do ouvir, do aprender, do crescer junto com o outro, da cooperação ética, que caracteriza a Prática Exploratória (Miller, 2010). Não necessariamente essa cooperação e harmonia serão alcançadas, mas haverá um trabalho para isso, que é a proposta da Prática Exploratória, que não foca no resultado, mas no processo. Nesse sentido, é interessante a afirmação de Walewska de que a Prática Exploratória é transgressora, por valorizar conceitos que não são valorizados em nossa sociedade.

Nesse mesmo trecho da Conversa, identifico a Proposição 2, pois a priorização do outro leva, inevitavelmente, a um ambiente de apoio mútuo. Os Princípios 3, 4 e 5, em minha opinião, aparecem juntamente com essas Proposições mencionadas, pois não há como haver uma priorização do próximo 
sem que haja um trabalho para a união de todos e para o desenvolvimento mútuo e, fatalmente, um envolvimento de todos.

Verificam-se, também, nessa passagem, diversos trechos de sobreposições cooperativas, que indicam uma conversa mais informal, não competitiva. As participantes projetam uma identidade de colegas, ao invés dos papéis de mestranda pesquisadora e professora exploratória que parecem ser mais constantes na Conversa 1 , devido à presença de menos sobreposições e turnos mais longos por parte da entrevistada. Além disso, as nossas sobreposições estão sempre se complementando, como se eu quisesse completar o pensamento de Walewska e vice-versa. Isso mostra o meu alinhamento com as ideias de Walewska e com a Prática Exploratória.

Dessa maneira, vimos que já na Entrevista, Walewska começa a projetar sua identidade de professora exploratória ao conseguir, em um trecho tão breve, mostrar o seu alinhamento com a filosofia exploratória.

\section{Quadro 7- Entrevista, Trecho 5}

\begin{tabular}{|c|c|c|}
\hline $\begin{array}{l}124 \\
125\end{array}$ & Vanessa & $\begin{array}{l}\text { [exatamente, será que } \\
\text { isso] é relevante prá nossa vi[da, eu acho?] }\end{array}$ \\
\hline 126 & Waleswka & {$\left[{ }^{\circ}\right.$ Exatamente $\left.^{\circ}\right]$} \\
\hline 127 & Vanessa & Será que isso vai... \\
\hline $\begin{array}{l}128 \\
129 \\
130 \\
131 \\
132 \\
133 \\
134 \\
135\end{array}$ & Walewska & $\begin{array}{l}\text { É, será que é, será que não é, né, acho que outras coisas são } \\
\text { interessantes também, num co..., nesse centro de estudos, né, eu } \\
\text { fico às vezes pensando gente, será que só eu que tô } \\
\text { pensando, mas depois eu vou assim, e vou vendo que outras } \\
\text { pessoas também falam, pensam, mas não falam. É que eu... né, } \\
\text { a prática exploratória me deu essa, essa...destrava, né? A } \\
\text { educação travou, a prática exp exploratória destravou, essa } \\
\text { não censura, dizer o que eu penso, não importa }\end{array}$ \\
\hline
\end{tabular}

Nesse trecho Walewska fala sobre um centro de estudos que acontece periodicamente na escola onde trabalha. Nesse momento, ela projeta sua identidade de professora exploratória, e fala como seu modo de portar-se frente ao mundo, no caso, seus colegas, também se modificou. Ela afirma sentir-se mais segura para expressar suas ideias e opiniões, independente do comportamento ou julgamento de outras pessoas. Nas linhas 125 e 126, a sobreposição é cooperativa, e mostra mais uma vez o meu alinhamento com as ideias da Prática Exploratória. 
Na linha 134, me chamou a atenção a afirmação de que "a educação travou, a prática exploratória destravou”. Ora, essa é uma afirmação até certo ponto contraditória com o senso comum de que a educação liberta ("Só a educação liberta" - frase atribuída a Epicteto, filósofo grego ${ }^{32}$ ) e com a noção de educação libertadora de Freire, cuja filosofia é amplamente divulgada no meio acadêmico e escolar. Então, afinal, a educação trava ou destrava? A educação como ela é, será que ela é realmente libertadora?

Gaiarsa (2008) parece dialogar com Walewska, ao entender que a sociedade educacional atual, ao estimular as crianças a reproduzir o status quo, não oferece necessariamente libertação, entendendo como liberdade aquilo que possa realmente afrouxar as amarras e levar a uma sociedade transformadora. A sociedade estimula a dependência excessiva, desde muito cedo. Nas palavras de Gaiarsa, "Desde seu primeiro dia nesse mundo a criança é... 'educada' (por omissão) para ser paralítica - desamparada, impotente e dependente.” (ibid, p.37). O ser dependente não é, absolutamente, um ser livre. Portanto, apesar das palavras tantas vezes ditas nos ambientes escolares, entre os professores, na prática a educação escolar em nada liberta, ao contrário.

Durante as aulas que observei, notei o engajamento de Walewska em dar voz aos alunos, em estimular que eles questionem e reflitam sobre a realidade que os cerca, conforme relatei no Anexo VI, na aula do dia 02 de setembro, na Turma 1, na ocasião do "mistério do mural":

Então, a professora perguntou-lhes porque, na opinião deles, as coisas desapareciam do mural, e eles responderam prontamente: "é a outra turma que rasga", "são eles", etc. Em nenhum momento me pareceu haver dúvida ou vontade de comprovar se foram os outros alunos mesmo que danificaram o mural. Eles sequer levantaram a hipótese de dar aos acusados o benefício da dúvida, ou de pesquisar, assumindo que os alunos acusados fossem mesmo os culpados, o porquê de eles agirem assim. Eles já sabiam a resposta: "são vândalos e maleducados".

Foi a professora quem suscitou essas questões e pediu que eles se dividissem em grupos e perguntassem a quem eles quisessem na escola (inspetores, professores, colegas, diretora), a opinião deles sobre a destruição do mural (porque eles achavam que isso acontecia, quem eram os responsáveis etc).

\footnotetext{
${ }^{32}$ Fonte http://educacao.uol.com.br/biografias/epicteto.jhtm em 03/01/2012.
} 
Vemos que a professora não se contentou com respostas prontas dadas pelos alunos, e os estimulou a pesquisar outras possibilidades. Em outra ocasião, na aula do dia 09 de setembro, na Turma 2, ao instituir o balcão de informações ${ }^{33}$ juntamente com a pesquisa com os dicionários, a professora também demonstra uma preocupação em estimular os alunos em buscar o conhecimento, ao invés de, literalmente, esperarem sentados pela resposta pronta da professora. É claro que ainda há certa passividade em ir à professora realizar a pergunta, mas considerando-se os parcos recursos à disposição dos alunos em sala de aula (dicionários e livro escolar), considero justificável e válido. Além das observações, a professora relata, mais adiante na Conversa 1, Trecho 9 (página 97, 1.313), o episódio do Khadafi ${ }^{34}$, e como ela respeitou a aluna, sem ridicularizá-la ou simplesmente rechaçar seu pensamento, mas buscou oferecer outros questionamentos e outra maneira de enxergar os acontecimentos.

Em nosso segundo encontro ${ }^{35}$, ao voltarmos a esse ponto, Walewska exemplificou com uma situação bastante corriqueira, conforme transcrição a seguir:

\section{Quadro 8- Conversa, Trecho 3}

\begin{tabular}{|c|c|c|}
\hline $\begin{array}{l}157 \\
158 \\
169 \\
160 \\
161 \\
162 \\
163\end{array}$ & Walewska & $\begin{array}{l}\text { Vai se formar, vai botar na fôrma. Então se bota na } \\
\text { fôrma...botou, sabe, a quantia exata, vai ficar ali. É nesse } \\
\text { sentido, é::, eu, aqui, eu tava falando...dessa destrava, é...de eu } \\
\text { poder formular, d'eu refletir, falar, né, e nesse contexto aqui, } \\
\text { num conselho de classe, todo mundo...têm ideias mais } \\
\text { fechadinhas, ou não...não se permite dizer, né...nesse sentido, } \\
\text { mas no sentido mais amplo, é a mesma coisa. }\end{array}$ \\
\hline $\begin{array}{l}164 \\
165\end{array}$ & Vanessa & $\begin{array}{l}\text { É a mesma coisa, a educação travou e >ainda continua } \\
\text { travando<...[né?] }\end{array}$ \\
\hline $\begin{array}{l}166 \\
167 \\
168 \\
169\end{array}$ & Walewska & $\begin{array}{l}\text { [quando você pergunta pro aluno o que é que você } \\
\text { acha, quando você tenta dialogar, negociar...nem sempre o } \\
\text { aluno entende isso, então ele pode entender que ah, com ela } \\
\text { qualquer coisa serve, ela é muito [boazinha]. }\end{array}$ \\
\hline $\begin{array}{l}170 \\
171\end{array}$ & Vanessa & $\begin{array}{l}\text { [O aluno fica] muito confuso. } \\
\text { [Eu ficava confusa], como aluna. }\end{array}$ \\
\hline 172 & Walewska & [ele fica confuso] \\
\hline
\end{tabular}

\footnotetext{
${ }^{33}$ Eu e a Walewska ficamos sentadas no meio da sala e os alunos, se tivessem dificuldades em realizar a atividade proposta, deveriam ir até nós para pedir auxílio, ao invés de nós irmos até eles todo o tempo.

${ }^{34}$ Ocasião em sala de aula quando a professora discutiu em sala de aula o linchamento do exditador líbio pela população.

${ }^{35}$ Anexo II, trecho 3.
} 


\begin{tabular}{|l|l|r|}
\hline 173 & Vanessa & Mas eu não tenho que saber, quem tem que [saber é você]. \\
\hline 174 & Walewska & [haha exatamente] \\
\hline
\end{tabular}

Em sala de aula, quando o professor pergunta ao aluno a sua opinião, na maioria das vezes o aluno se sente extremamente confuso e ludibriado. Afinal, o professor é quem deve saber o melhor caminho, a melhor resposta, o professor é quem tem a opinião certa. Portanto, se o professor pergunta ao aluno, ou deixa o aluno decidir algo sobre sua avaliação ou sobre o seu currículo, o aluno muitas vezes duvida da própria capacidade do professor enquanto profissional. $\mathrm{O}$ aluno está tão acostumado e acomodado com o receber e aceitar ordens, que qualquer coisa que desvie desse comportamento "padrão", às vezes, é entendido como incompetência por parte do profissional. Dito isso, só posso concordar com Gaiarsa e com Walewska, ao reafirmarem que, apesar de Paulo Freire, o sistema educacional de nossa sociedade ainda não é libertador.

Nas linhas 157 a 163, Walewska exemplifica com um termo usado quando o aluno conclui alguma etapa do ensino formal: o aluno se forma no Ensino Fundamental, depois se forma no Ensino Médio e, mais adiante, se forma na faculdade. E, assim as pessoas, após a formatura, tendem a reproduzir ideais e filosofias aprendidas, ao invés de refletir sobre novos caminhos. É como se o pensamento autônomo fosse "travado". Nessa parte da explicação, não há sobreposições.

Nas linhas 164 e 165 eu inicio um trecho que mostra que eu estou acompanhando e entendendo o raciocínio da professora, e ao final do trecho há uma pequena sobreposição cooperativa (1. 165 e 166), ao final do meu turno e início do turno de Walewska. Tal sobreposição mostra o entrosamento e engajamento das participantes na conversa, e mais uma vez, meu crescente alinhamento com as ideias discutidas por Walewska.

Acredito que o maior número de sobreposições nesse trecho se deve ao fato de eu, Vanessa, ter me portado mais como uma colega que também tem experiências para dividir do que como aluna mestranda que busca entender e buscar informações de outra profissional. Dessa maneira, me preocupei menos em deixar que Walewska mantivesse o piso conversacional por mais tempo e, assim, 
as sobreposições ocorreram próximas a momentos de transição de turno e se tornaram mais frequentes.

Ainda nesse trecho, noto a Walewska se projetando como professora exploratória, questionadora e, por vezes, boazinha na visão dos alunos, que não compreendem as reais motivações por trás das suas atitudes.

Outro ponto interessante da primeira conversa está no trecho seguinte:

\section{Quadro 9- Entrevista, Trecho 6}

\begin{tabular}{|c|c|c|}
\hline 170 & Vanessa & Que houve uma $^{\circ}$ denúncia $^{\circ} \ldots$ \\
\hline 171 & Waleswka & Houv...[sim...] \\
\hline 172 & Vanessa & [Cê acha $]$ que... \\
\hline 173 & Waleswka & Eu acho que não, não tinha a ver... \\
\hline 174 & Vanessa & $1 . . . /$ \\
\hline 175 & Walewska & [Se] estamos errados, nós não temos que ficar indignados, nós \\
\hline 176 & & temos que ver, ah mas nós não podemos, é muito longe, os \\
\hline 177 & & alunos não chegam, pro professor também tem obras...então \\
\hline 178 & & 个isso não é um assunto pra se tratar?, ou seja, o aluno tem \\
\hline 179 & & um...Riocard. O Riocard permite que ele faça cinco viagens. \\
\hline 180 & & Então, a solução da Direção é: se ele não...ele vem, né? Eu \\
\hline 181 & & venho. Saio do de Ipanema, posto seis, enfim...eh...eu posso \\
\hline 182 & & pegar dois ônibus. Eu, eu aluno, né? Eu pego dois ônibus prá \\
\hline 183 & & $>$ chegar no horário<. Gente, mas isso não está certo, porque \\
\hline 184 & & aquilo custa. Quem paga é o contribuinte, isso sai do dinheiro \\
\hline 185 & & dos impostos. Aquela 个passagem não é gratuita. Então 个olha \\
\hline 186 & & que oportunidade a escola tem...um assunto que >é \\
\hline 187 & & importante, é vital< prá escola: como chegar na hora certa. \\
\hline 188 & & Porque chegar na hora certa $\uparrow ?$ Porque não usar cinco $\uparrow ?$ Que é \\
\hline 189 & & a questão ética. E...foi resolvido, e, o eh...eh, \\
\hline
\end{tabular}

Esse trecho é bastante rico na análise das identidades projetadas pela professora Walewska. Na linha 175, ao afirmar que "se estamos errados, não temos que ficar indignados", ela projeta uma identidade de professora, participante da comunidade escolar, contestadora, que busca assumir responsabilidade pelos seus atos. Nas linhas 176 e 177 ela começa a exposição dos obstáculos à solução do problema, antes de novamente, na linha 178, com a frase “isso não é um assunto para se tratar?", reiterar sua identidade de professora contestadora e questionadora. 
Nas linhas 182 a 185 a professora mostra uma posição firme e antagônica àquela defendida pela direção da escola. Os argumentos que ela utiliza a projetam identitariamente não apenas como professora exploratória, ética e comprometida, mas como cidadã brasileira, carioca e contribuinte, que pretende agir da maneira mais econômica e melhor para a coletividade.

Continuando, nas linhas 180 a 189, Walewska mais uma vez se projeta principalmente como educadora reflexiva, moral e ética. Durante sua narrativa, ela propõe questões relevantes e que, a seu ver, deveriam ser discutidas na comunidade escolar como um todo (incluindo os alunos), de forma exploratória, projetando, portanto, também, a identidade de professora exploratória, que envolve todos, dentro e fora da sala de aula.

Relacionando o trecho aos Princípios da Prática Exploratória, vimos que Walewska questiona a solução simplista dada pela escola ao dilema apresentado (linhas 182 a 189). Na visão da professora, a questão do transporte até a escola é uma questão extremamente prática, no sentido de ser real, e discussões extremamente pertinentes à realidade do corpo discente poderiam (e deveriam) terem sido estimuladas. Noções de cidadania, de economia, de ética, de política, que poderiam ser discutidas foram deixadas de lado. A professora então defende aqui o Princípio 3 e o Princípio 6, que seria integrar uma questão social, política e economicamente relevante para todos, à sala de aula, estimulando o debate e a reflexão. Com tudo isso, essa passagem mostra o alinhamento de Walewska com a posição do professor como intelectual transformador (v. p 12).

De maneira coerente com o seu discurso, os comentários de Walewska nas minhas anotações, no dia 02 de setembro, turma 1, pág 130, ela questiona novamente a solução dada pela escola na questão do "mistério do mural". Ao invés de um trabalho reflexivo e investigativo, a escola solucionou o problema mudando o mural para a sala de leitura, negligenciando mais uma ótima oportunidade de reflexão: 
Mas o interessante e inesperado (?!) é que o mistério terminou quando a professora da sala de leitura me disse que achou o mural da 1801 tão lindo que retirou da sala antes que os vândalos destruíssem e deixou na sala de leitura... Meu Deus!!!!! Isso é possível???? Só em escola mesmo...O mistério acabou mas as questões ficaram!!! ${ }^{36}$

Entendo que Walewska considera que essas teriam sido excelentes oportunidades para uma APPE (atividade pedagógica com potencial exploratório), através da qual a professora poderia estimular os alunos a refletirem criticamente sobre a realidade social que se lhes apresenta, através da elaboração, reflexão e discussão sobre a questão do "chegar atrasado" à escola, do transporte público, e de como preservar e respeitar o trabalho do amigo.

Um pouco mais adiante, Walewska retorna a esse mesmo ponto, reforçando o comentário analisado anteriormente, e reafirmando sua visão transformadora da educação (linhas 200 a 208 e linhas 215 a 223).

\section{Quadro 10- Entrevista, Trecho 7}

\begin{tabular}{|c|c|c|}
\hline $\begin{array}{l}193 \\
194\end{array}$ & Waleswka & $\begin{array}{l}\text { Porque...infelizmente eu acabo falando, né? Eu digo pros } \\
\text { meninos, vocês não podem falar [quem é o professor] }\end{array}$ \\
\hline 195 & Vanessa & {$[($ risos $)]$} \\
\hline 196 & Walewska & Mas a gente acaba...né? É interessante que a gente vê isso, \\
\hline 197 & & como sai naturalmente...mas...o coordenador falou: Mas nós \\
\hline 198 & & não temos que resolver esse problema. Se é problema de \\
\hline 199 & & transporte eles têm cinco...passagens, eles usem as cinco \\
\hline 200 & & passagens! > Quer dizer $<\ldots$ Me parece que as as coisas que \\
\hline 201 & & precisam ser faladas, estudadas, entendidas...exploradas...você \\
\hline 202 & & pode >pegar isso, matemática história<...é ético, é tudo. Você \\
\hline 203 & & deixa pro lado e aí você tem que...o problema é: fulaninho saiu \\
\hline 204 & & de casa às nove horas, se atrasou, que horas ele, quanto tempo \\
\hline 205 & & ele perdeu, não interessa! Não é botar o nome, Joãzinho, prá \\
\hline 206 & & dizer que é atual...ou botar um nome Gabriele, \\
\hline 207 & & ou...Daiane...não é isso que ${ }^{\circ}$ faz ser relevante ${ }^{\circ}$. O que faz \\
\hline 208 & & releva ser relevante é o assunto. Então existiu essa questão no \\
\hline 209 & & conselho de classe ${ }^{38}$. Como é que a gente vai decidir isso $\uparrow ?$ \\
\hline 210 & & Com os pais, com os alunos...esse é o caminho da prática \\
\hline 211 & & exploratória. É ver a questão que existe, e ela existe a cada \\
\hline 212 & & momento, era uma 个reunião de professores...e é uma questão \\
\hline
\end{tabular}

\footnotetext{
${ }^{36}$ Mantive o itálico e o negrito para preservar a formatação original do trecho escrito por Walewska

${ }^{37}$ A situação na qual a professora orienta os alunos a não falar o nome do professor é quando eles apresentam pôsteres e algum professor citado não está presente.

${ }^{38} \mathrm{Na}$ conversa seguinte, Walewska já havia lido a transcrição e esclareceu que aqui ela quis dizer "centro de estudos", e não "conselho de classe".
} 


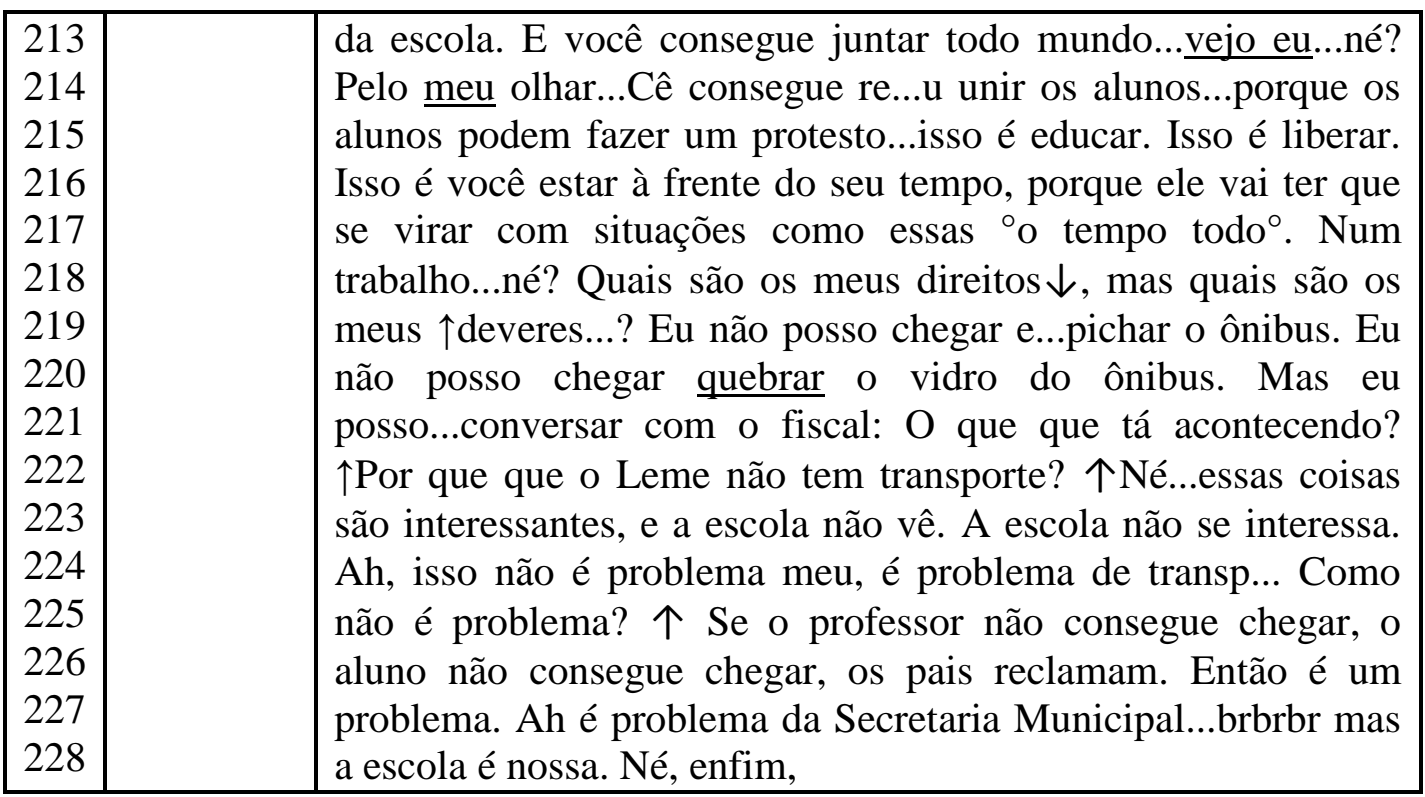

Nesse trecho, nas linhas 200 e 201, Walewska projeta sua identidade de professora exploratória, ao oferecer sua visão de como as questões deveriam ser trabalhadas na comunidade escolar. Ao enfatizar as palavras "estudadas, entendidas, exploradas", a professora demonstra sua crença na problematização e democratização das questões apresentadas. E, na linha 202, ao afirmar que tal atitude é "ética", ela se projeta não apenas como professora exploratória, mas, num sentido mais amplo, como educadora que, independente da matéria que leciona, sente-se responsável pela formação de cidadãos e seus valores.

Nas linhas 207 e 208, ao afirmar que "o que faz ser relevante é o assunto", e nas linhas 211 e 212, ao dizer "a questão que existe a cada momento", ela mais uma vez reflete suas crenças e se projeta como professora exploratória. A ênfase na palavra "questão", e a repetição dessa palavra em outros momentos do trecho, mostra, em minha opinião, além da identificação de Walewska com a Prática Exploratória, que também trabalha com questões, como a professora evita estabelecer-se como alguém que possui respostas, preferindo projetar-se como uma profissional que propõe perguntas. Assim, Walewska não está discordando da solução dada pela escola, mas discorda do meio utilizado para se chegar a essa conclusão.

Nas linhas 213 e 214 a professora enfatiza as palavras "eu" e "meu", ressaltando que tudo o que está sendo dito é a interpretação dela diante dos fatos. 
Com isso, ela admite a existência de outras interpretações igualmente válidas, e se projeta como uma profissional democrática e aberta a discussões. Aliás, todo o tempo ela reforça a postura de que a discussão, a problematização, o debate, o falar e refletir conjuntamente sobre o assunto são importantes para um melhor entendimento dos fatos. E, mais uma vez, ratifica a postura adotada anteriormente, e justifica a ênfase na palavra "questão", discutida no parágrafo anterior.

As frases “isso é educar. Isso é liberar. Isso é você estar à frente do seu tempo.” (linhas 215 e 216), ratificam esse tom partidário assumido pela professora, que estão em consonância com a ideia professores como intelectuais transformadores de Giroux e da pedagogia crítica de Freire.

De acordo com a fala da professora, durante a observação das aulas, no Anexo $\mathrm{V}$, no dia 02 de setembro, nos comentários da professora sobre as minhas anotações, na Turma 1, ela conta como o "mistério do mural",39 (uma APPE realizada pela professora Walewska de maneira a entender porquê o mural dos alunos em sala de aula era sempre destruído) foi "resolvido": transferindo-o para a sala de leitura. Dessa maneira, segundo a professora, acaba-se o "mistério", mas os questionamentos permanecem, e nada é, de verdade, resolvido, como acontece na questão da passagem: utilizar mais passagens, será essa a melhor solução? O que essa atitude resolve? E o que ela não resolve? Essas são questões que, segundo a professora exploratória, mereciam maior atenção por parte da comunidade escolar. Dessa maneira, agiríamos de acordo com a Proposição 4 -alunos são capazes de tomar decisões independentemente - e, da Proposição 5 -alunos como praticantes do próprio aprendizado --, além do Princípio 1 -priorizar a qualidade de vida, já que é uma questão que afeta toda a comunidade e o Princípio 2 -- ao explorar essas questões mais profundamente, eles estariam trabalhando para entender a vida não somente da sala de aula, mas também fora dela, já que era uma questão da escola mas que passava pela utilização de verbas públicas.

Nas linhas 218 e 219, ao falar sobre a importância de se trabalhar com os conceitos de direitos e deveres em sala de aula, e nas linhas 222 e 223, ao afirmar “essas coisas são interessantes, e a escola não vê. A escola não se interessa.",

\footnotetext{
${ }^{39}$ Será explicado mais detalhadamente na próxima página
} 
Walewska mais uma vez se projeta como professora exploratória e educadora, ecoando também os Princípios de educação libertadora de Paulo Freire.

Ao observar as aulas, percebia e registrava em minhas anotações, que a preocupação da professora em ir além do conteúdo programático de sua disciplina (Inglês) era clara e coerente com sua fala durante a conversa. Um bom exemplo foi a tentativa de mobilização de uma turma para solucionar o que foi chamado de "o mistério do mural" ${ }^{40}$. O mural confeccionado pelos alunos durante as aulas de inglês era arrancado e rasgado de uma semana para outra, e os alunos ficavam chateados por terem seus trabalhos destruídos. Através de uma APPE, Walewska procurou estimular os alunos a refletir sobre a importância de se preservar os objetos, os bens materiais (e imateriais), sejam eles públicos ou privados. Ou seja, a professora, ao fazer a escolha pedagógica de utilizar seu tempo de aula para discutir questões éticas, ao mesmo tempo em que ensinava gramática e vocabulário, reforçou a identidade de profissional libertadora e exploratória que ela mostrou na entrevista, e agiu de maneira condizente com o seu discurso.

Essa postura da professora está em consonância com as Proposições 3 e 4 da Prática Exploratória -- alunos são capazes de levar o aprendizado a sério; alunos são capazes de tomar decisões independentemente -, já que a professora cria oportunidades para que os alunos tomem consciência de suas ações e aprendam através de reflexões sobre o cotidiano. Walewska pretende que seus alunos efetivamente aprendam a refletir e a repensar, e não apenas a memorizar e a reproduzir.

O próximo fragmento a ser analisado é continuação do trecho anterior:

\footnotetext{
${ }^{40}$ Anexo V, dia 02 de setembro, Turma 1.
} 


\section{Quadro 11- Entrevista, Trecho 7}

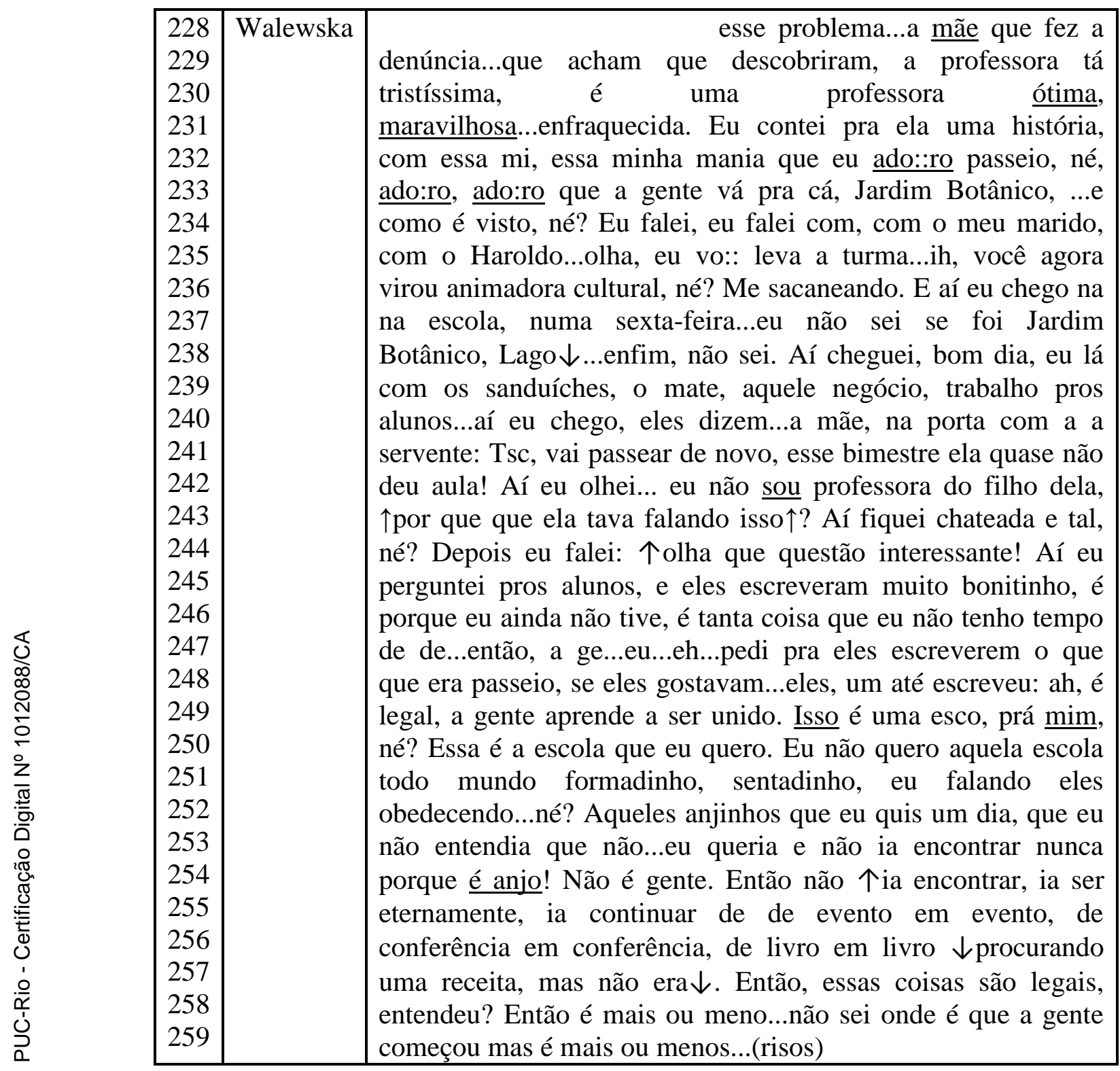

Nesse trecho vemos como a conversa fica mais informal, como uma conversa entre colegas de profissão, o que pode ser notado através do uso da expressão "me sacaneando" (1.236) e, na parte final (linhas 267 a 259), quando Walewska diz “(...) essas coisas são legais, entendeu? (...) não sei onde é que a gente começou mas é mais ou menos..." e ri. O uso de gírias, e a própria professora admitir que não sabe como começou a falar do assunto, mostram um comportamento típico de quem não tem obrigações com a forma, transparecendo, também, o ambiente de relaxamento e descontração da conversa. 
Nessa parte, Walewska narra uma ocasião em que se depara com uma situação frustrante (linha 243), e resolve buscar um maior entendimento sobre o desconforto (linhas 244 a 248). Interessante notar que a professora também projeta uma identidade maternal, ao narrar sua experiência em um passeio ao Jardim Botânico, quando levou mate e sanduíches para os alunos (linhas 238 e 239). Entendo que essa atitude seja maternal, pois nunca presenciei ou ouvi falar de alguma outra professora que tenha se preocupado em preparar lanche para os seus alunos levarem a um passeio extraclasse. Em minha opinião, isso mostra não só o engajamento, o compromisso e a paixão da professora pela sua profissão, mas também seu carinho pelos alunos.

Apesar da frustração gerada pelo comentário ouvido na porta da escola (linhas 240 a 242), Walewska voltou-se aos seus alunos para que eles the dissessem o que sentiam, como viam, percebiam e entendiam o passeio, e a resposta de um aluno "a gente aprende a ser unido" (linha 249), a fez ficar satisfeita consigo mesma, pois sentiu que seu objetivo como professora estava sendo alcançado (linha 250: "essa é a escola que eu quero"). Desse modo, o aluno, com sua resposta, mostra seu alinhamento com a Proposição 2 da Prática Exploratória -- alunos são seres sociais que aprendem e se desenvolvem melhor em sua própria idiossincrasia -- e com os Princípios 3 e 4 -- envolver todos no trabalho e trabalhar para a união de todos. Além disso, é válido lembrar a posição de Gaiarsa, ao afirmar a importância da escola como um dos lugares onde iniciase o relacionamento social (v. p. 18).

Vejo Walewska alinhar-se ao pensamento de Gaiarsa ao entender que a experiência escolar pode e deve ser prazerosa, e não totalmente focada no conteúdo a ser aprendido, com os alunos sentados por horas, formados, concentrados (linhas 251 a 253), como se fossem anjos ${ }^{41}$. De modo a reforçar a ineficácia da estrutura escolar convencional (alunos sentados por horas a fio, concentrados por toda a manhã ou tarde (normalmente de 07h da manhã às $11 \mathrm{~h} 40$, com 15 a 30 minutos de intervalo somente), um artigo publicado no site www.globo.com, sobre a educação na Finlândia, país que "está em primeiro lugar

\footnotetext{
${ }^{41}$ Aqui a professora faz menção a uma APPE que realizou nesse mesmo colégio, na qual os alunos refletiram sobre seu próprio comportamento em sala de aula e se dividiram em anjos, vampiros e "fantasminhas camaradas". No Anexo III há o relato de Walewska sobre o desenvolvimento dessa atividade.
} 
no índice de educação global publicado pela ONU em 2008" (artigo http://exame.abril.com.br/economia/mundo/noticias/4-fatos-curiosos-que-fazemda-educacao-na-finlandia-um-exemplo ${ }^{42}$ ), mostra como esse país adota uma rotina de estudos diferenciada:

Como parte de uma reforma no ensino feita na década de 1970, o país (...) garante liberdade às escolas para trabalhar o próprio currículo e dá pouca atenção a avaliações e dever de casa.

(...)

Segundo a OECD (Organização para a Cooperação e Desenvolvimento Econômico), as crianças finlandesas são as que passam menos horas dentro de sala de aula entre os países desenvolvidos.(...) Os "intervalos" podem, durar até 75 minutos e a lição de casa não é uma prática incentivada antes que os alunos cheguem ao meio da adolescência, por volta dos 16 anos de idade.

Ou seja, ao escolher seu próprio currículo, a instituição de ensino finlandesa pode melhor adaptá-lo às necessidades e interesses de seus alunos, tornando assim o aprendizado mais útil e prazeroso. Intervalos longos também são um diferencial que garantem horas de relaxamento e diversão que, via de regra, são bem escassos no dia letivo de uma escola brasileira. E nada disso interfere negativamente no aprendizado dos alunos. Dessa maneira, entendo que a educação escolar finlandesa acaba ecoando, com bons resultados, as Proposições da Prática Exploratória (v. págs. 20 e 21).

Walewska, ao levar os alunos para um "passeio", também demonstra acreditar no aprendizado que um evento prazeroso pode gerar. A professora, além de aumentar a sensação de bem-estar no ambiente escolar, também trabalha, indiretamente, a noção de união, como bem demonstrou o depoimento de seu aluno $^{43}$. Esses momentos também refletem o primeiro Princípio de Prática Exploratória, que é priorizar a qualidade de vida, conceito infelizmente tão ausente da realidade da maioria das pessoas atualmente.

O trecho 8, imediatamente subsequente, é rico em sobreposições cooperativas. Além de eu e Walewska revisitarmos temas já abordados, eu falo

\footnotetext{
${ }^{42} \mathrm{O}$ artigo encontra-se, na íntegra, no Anexo IV.

${ }^{43}$ Temos acesso a esse depoimento através da fala da Walewska.
} 
sobre o meu processo de convencimento sobre a viabilidade da Prática Exploratória.

Quadro 12- Entrevista, trecho 8

\begin{tabular}{|c|c|c|}
\hline 261 & Vanessa & $>$ Você acha que, tipo assim< \\
\hline 262 & Walewska & Boa sorte na transcrição \\
\hline 263 & Vanessa & Olha só...não acabou ainda. \\
\hline 264 & Walewska & Risos...mas é hilário. \\
\hline 265 & Vanessa & Não, não é não, eu acho legal. \\
\hline 266 & Walewska & Ai... \\
\hline $\begin{array}{l}267 \\
268 \\
269 \\
270 \\
271 \\
272\end{array}$ & Vanessa & $\begin{array}{l}\text { Eu acho...é porque eu acho que é mais ou menos...é mais ou } \\
\text { menos o que eu penso também, é mais ou menos...o que eu...o } \\
\text { que eu...também...eu eu chego à conclusão } \\
\text { porque...na...quando eu comecei na Prática Exploratória, eu } \\
\text { não entendia nada, também achava aquilo uma coisa de } \\
\text { louco... }\end{array}$ \\
\hline 273 & Walewska & Risos...é muito diferente, [né? É muito diferente.] \\
\hline $\begin{array}{l}274 \\
275\end{array}$ & Vanessa & $\begin{array}{l}\text { [Eu não entendia, e hoje em dia] } \\
\text { eu vejo...> de uma maneira muito clara }<\end{array}$ \\
\hline 276 & Walewska & {$[\mathrm{E}]$} \\
\hline $\begin{array}{l}277 \\
278\end{array}$ & Vanessa & $\begin{array}{l}\text { [mas] eu também entendo que as pessoas não conseguem } \\
\text { enxergar porque o mundo não é feito }>\text { pra isso }<\text {. }\end{array}$ \\
\hline 279 & Walewska & {$[$ É. $]$} \\
\hline $\begin{array}{l}280 \\
281 \\
282 \\
283\end{array}$ & Vanessa & $\begin{array}{l}\text { [O mundo], ele ele ele tolhe primeiro sua capacidade de } \\
\text { raciocínio, ele embota...muitas vezes...e você, é incapaz de } \\
\text { > você refletir criticamente<, então você chega, você faz, você } \\
\text { reproduz um padrão, que lhe foi ensinado, }\end{array}$ \\
\hline 284 & Walewska & Que você sabe [que é falho] \\
\hline $\begin{array}{l}285 \\
286 \\
287\end{array}$ & Vanessa & $\begin{array}{l}\text { [e prá], }{ }^{\circ} \text { aquilo é certo prá } \\
\text { vocế }{ }^{\circ} \text {, eh você jamais parou prá pensar...se é ou se não é, } \\
\text { refletir de verdade. }\end{array}$ \\
\hline 288 & Walewska & [É.] \\
\hline
\end{tabular}

As sobreposições cooperativas ocorrem de maneira que uma tenta se adiantar e finalizar a fala da outra, e isso mostra não só o entrosamento, mas também, e principalmente, o alinhamento de ideias, e como Walewska e eu dividimos as mesmas opiniões sobre como deve ser uma sala de aula. Isso transparece o meu processo de convencimento, pois, como foi dito no início do trabalho, eu tinha dificuldades em vislumbrar a aplicação da Prática Exploratória numa sala de aula real. Após o relato de Walewska sobre os passeios dos alunos aos parques da cidade (Entrevista, trecho 7), e sua reflexão a respeito, eu passo a entender melhor como a Prática Exploratória funciona, seus objetivos, e assim, afirmo que passei a entender o conceito. 
Quadro 13- Entrevista, Trecho 9

\begin{tabular}{|l|l|l|}
\hline 289 & Vanessa & [Eu] acho que isso...é uma oportunidade. [Eh, é super legal.] \\
\hline 290 & Walewska & [É, tudo é] tem assim \\
291 & & umas partes, eh, eu...até às vezes fico assim achando que eu \\
292 & & vou de de frase...de de...eh...citação em citação do Allwright. \\
293 & & Logo no início eu gostava muito, porque era significativo pra \\
294 & & mim, a história da eficiência. Não busque eficiência, busque \\
295 & & entender...Ou seja...o $\uparrow$ resultado, ele vai vir $\downarrow$. Mas se você \\
296 & & entender...que é difícil, que vai demorar...que o menino \\
297 & & naquele momento não podia mesmo te prestar atenção no que \\
298 & & você tava falando porque ele saiu de casa, e...viu uma briga, \\
299 & & viu um cadáver, eu sei lá, enfim, o que que acontece com eles. \\
300 & & Ou $\uparrow \underline{\text { simplesmente estar sonhando com a namorada, como os }}$ \\
301 & & meninos do nono ano com a deusa...dourada, né? Aquela \\
302 & & deusa, que eles adoram, aí eles chegam todos atrasados, ao \\
303 & & mesmo tempo, a deusa na frente, e eles atrás....mas é bonito \\
304 & & aquilo, né? É lindo, é vida.
\end{tabular}

No trecho acima a professora cita uma frase de Allwright, segundo a qual ele diz que não se deve buscar a eficiência, mas o entendimento ${ }^{44}$ (linhas $294 \mathrm{e}$ 295). Segundo Allwright, não há como tentar implementar mudanças sem antes haver entendimento. Uma mudança implementada sem reflexão prévia, só obterá os resultados esperados por sorte. Isso se soubermos quais os resultados almejados, já que não houve reflexão prévia. (Allwright, 1998)

A Prática Exploratória defende que, ao se procurar entender uma situação, descobriremos, inevitavelmente, outras formas de olhar para ela. Podemos enxergar nuances que não estavam óbvias anteriormente como podemos, também, confirmar o nosso pensamento anterior. Ao revisitarmos esse tópico em nossa conversa posterior, Walewska diz:

\footnotetext{
${ }^{44} \mathrm{~A}$ professora explica a frase à sua própria maneira na transcrição desse encontro, no Anexo IV.
} 


\section{Quadro 14- Conversa, Trecho 4}

\begin{tabular}{|c|c|c|}
\hline $\begin{array}{l}175 \\
176 \\
177 \\
178 \\
179 \\
180 \\
181 \\
182 \\
183 \\
184 \\
185 \\
186 \\
187 \\
188 \\
189 \\
190 \\
191 \\
192 \\
193 \\
194 \\
195 \\
196 \\
197 \\
198 \\
199 \\
200 \\
201 \\
202 \\
203\end{array}$ & Walewska & $\begin{array}{l}\text { O que, o que é...me encantou muito nessa história da } \\
\text { eficiência é porque obviamente eu buscava eficiência, eu } \\
\text { queria ser uma professora melhor, né...eu queria, é, que as } \\
\text { aulas fossem alguma coisa...excepcional...é...e quando eu li } \\
\text { Allwright ele diz, não se preocupe com a eficiência, procure } \\
\text { entender. Porque quando você entende o que tá acontecendo } \\
\text { na sua sala...se o aluno chegou atrasado...porque o } \\
\text { ônibus...não chegou...ele veio da Rocinha, até chegar aqui, ele } \\
\text { chega atrasado...se ele tá cansado porque ele trabalhou à } \\
\text { noite....se todas essas coisas humanas fazem parte da sua aula } \\
\text { também, você não tá buscando essa eficiência de resultado, } \\
\text { mas você tá buscando essa eficiência do entendimento e essa } \\
\text { eficiência do ser humano, porque eu entendi você, eu entendi } \\
\text { o outro. Nesse momento ele não pode, mas isso não quer dizer } \\
\text { que eu vá desistir dele, eu vou apresentar de um outro jeito, eu } \\
\text { vou...é:.:. eu vou buscar uma outra coisa, né? Se o aluno, eu } \\
\text { sei, naquele momento ele não pode fazer mas ele não quer } \\
\text { dizer que ele não queira fazer. Eu não vou simplesmente } \\
\text { rotular: ele é chato, ele é burro, ele não sabe, ele não faz, ele } \\
\text { não quer...eu tenho que tentar entender, ou busca::r uma saída, } \\
\text { ele precisa de um acompanhamento...né? Mas eu vou ter um } \\
\text { olhar, pra ele, humano. Então é nesse sentido porque quando } \\
\text { você começa a ver por isso, Vanessa, você querendo ou não } \\
\text { você se aproxima da eficiência....né? Não, talvez, do 10, do } \\
\text { índice, do tal, mas da eficiência do ensino libertador...né, não } \\
\text { do que trava. O que trava é do índice. Mas o que liberta. } \\
\text { Porque ele entendeu também, ah, nesse momento não dá pra } \\
\text { eu fazer, /.../, meus pais brigaram, meu pai saiu de casa, minha } \\
\text { mãe casou de novo...[né?] }\end{array}$ \\
\hline
\end{tabular}

Nesse trecho Walewska diz que ao lidar com a realidade da sala de aula levando-se em conta o aspecto humano de seus alunos, nos aproximamos mais da "eficiência do ensino libertador" (1.199). Nesse ponto, ela ressignifica eficiência.

Enquanto, para os parâmetros governamentais, a eficiência é traduzida em um índice, calculado de acordo com a performance dos alunos em um exame anual, para Walewska a verdadeira eficiência consiste em transformar os alunos em adultos capazes de pensar criticamente a realidade, lidar com os obstáculos que a vida oferece e criar alternativas. Para isso, é imprescindível que o professor compreenda as necessidades do aluno, tente entender sua realidade, e se coloque disponível para ajudá-lo a superar suas dificuldades. Isso é essencial para que o aluno perceba que soluções podem ser encontradas, e que nós somos os 
responsáveis pelas nossas escolhas, cabendo somente a nós lutar pelos nossos objetivos. Se o aluno cresce em um ambiente em que ninguém acredita nele, nem os pais nem os professores, e em uma realidade em que a única coisa que importa é a nota que você obtém ao final do semestre, não importando o que se fez para conseguir essa nota (seja "colando" ou estudando, o importante é o resultado), então não se pode culpá-lo por reproduzir esse raciocínio em outros aspectos de sua vida.

Afinal, há vários caminhos para se chegar a um resultado definido anteriormente e, quando esse é o foco, a compreensão e o desenvolvimento crítico dos alunos fica em segundo plano. Mas, se o foco for o desenvolvimento do aluno como pensador crítico, alinhando-se, dessa maneira, com a ideia do professor como um intelectual transformador, então a "eficiência do entendimento" (1.186), que, para Walewska e para mim, é mais importante, será mais facilmente alcançada.

Vemos, então, que Walewska e eu acreditamos que a busca para o entendimento é mister. Muitas vezes, observamos que a busca pela "eficiência de resultado" leva muitos professores (gestores, pais, mães etc) a implementarem mudanças, sem haverem verdadeiramente entendido a situação que querem modificar. Dessa maneira, cito Allwright (1998) :

2. A lógica de planejar mudanças específicas pressupõe que nós podemos afirmar entender uma situação o suficiente para saber:

1.1. precisamente em quais aspectos a situação é problemática; para que assim possamos saber

1.2. precisamente quais mudanças específicas são necessárias e suficientes para que a situação seja melhorada; $\mathrm{e}$

1.3. precisamente como tais mudanças podem ser seguramente implementadas.

3. Mas isso também implica que a situação 'problemática' é 'estática' o suficiente para poder ser 'completamente mapeada', e não dinâmica a ponto de seu mapeamento não ser possível.

4. Ainda assim, somos constantemente alertados que mudanças rápidas e constantes estão ocorrendo o tempo todo, quer gostemos ou não, e que tais mudanças são inevitáveis. 
5. E sabemos, de qualquer modo, que em assuntos humanos tudo muda realmente, mais ou menos subitamente, e mais ou menos rapidamente, com o tempo.

6. Então, se nós acreditarmos (de acordo com o ponto 5 acima) que todas as situações humanas são inerentemente e endemicamente dinâmicas, e que (de acordo com o ponto 4), a mudança rápida e constante é inevitável, certamente não podemos acreditar que as situações para as quais se almeja uma mudança serão suficientemente conhecidas a ponto de sermos capazes de planejar mudanças específicas e de modo que tenhamos certeza tanto de selecionar as mudanças que irão indubitavelmente 'melhorar' a situação, e não piorá-las, quanto de conduzir o processo de mudança de modo que as mudanças pretendidas, e somente elas, ocorram.

7. Somos, portanto, levados a concluir que planejar uma mudança específica está além de nossa capacidade, e talvez seja assim eternamente - já que tudo está fadado a ser eternamente dinâmico e, portanto, tudo está também fadado a ser eternamente insuficientemente conhecido. ${ }^{45}$

Assim, entendo que a mudança deve ocorrer é em nós mesmos, e na nossa forma de lidar com a realidade.

O próximo fragmento do Trecho 9 a ser analisado reforça o Princípio 2 da Prática Exploratória - trabalhar para entender a vida em sala de aula -, nas linhas

\footnotetext{
${ }^{45}$ Tradução livre de 2. But the logic of planning for specific change presupposes that we can reasonably claim to understand a given situation well enough to know:

1.1 precisely in what respects it is problematic; so that we can also claim to know

1.2 precisely what specific changes would be necessary and sufficient in order for that situation to be 'improved'; and

1.3 precisely how such changes could reliably be brought about.

3. But this also implies that the current 'problematic' situation is at least 'static' enough to be 'precisely knowable', and not a dynamic one that is changing so fast that it is essentially 'unknowable'.

4. And yet we are constantly being told that constant and rapid change is taking place all the time whether we like it or not, and that such rapid constant change is now inevitable.

5. And we know, anyway, that in human affairs everything does change, more or less subtly, and more or less rapidly, over time.

6. So, if we do seriously believe (with point 5 above) that all human situations are inherently, endemically, dynamic, and that (with point 4) constant and rapid change is now inevitable, surely we cannot simultaneously believe that the situations people see as in need of 'improvement' are nevertheless sufficiently 'knowable' (ie predictable) at any one point in time for us to be able to plan specific change so that we can be sure both of selecting those changes that can be guaranteed to 'improve' situations, rather than to make them worse, and also of conducting the change process in such a way that the desired changes, and only the desired changes, will take place.

7. We are thus lead to conclude, surely, that planning specific change is currently beyond us, and perhaps inevitably and eternally so - if all is doomed to be eternally dynamic and therefore all is also doomed to be eternally insufficiently knowable.
} 
313 a 319, quando a professora reafirma a importância de se discutir os acontecimentos sociais, ao invés de ater-se tão somente ao livro didático ${ }^{46}$;

\section{Quadro 15- Entrevista, Trecho9}

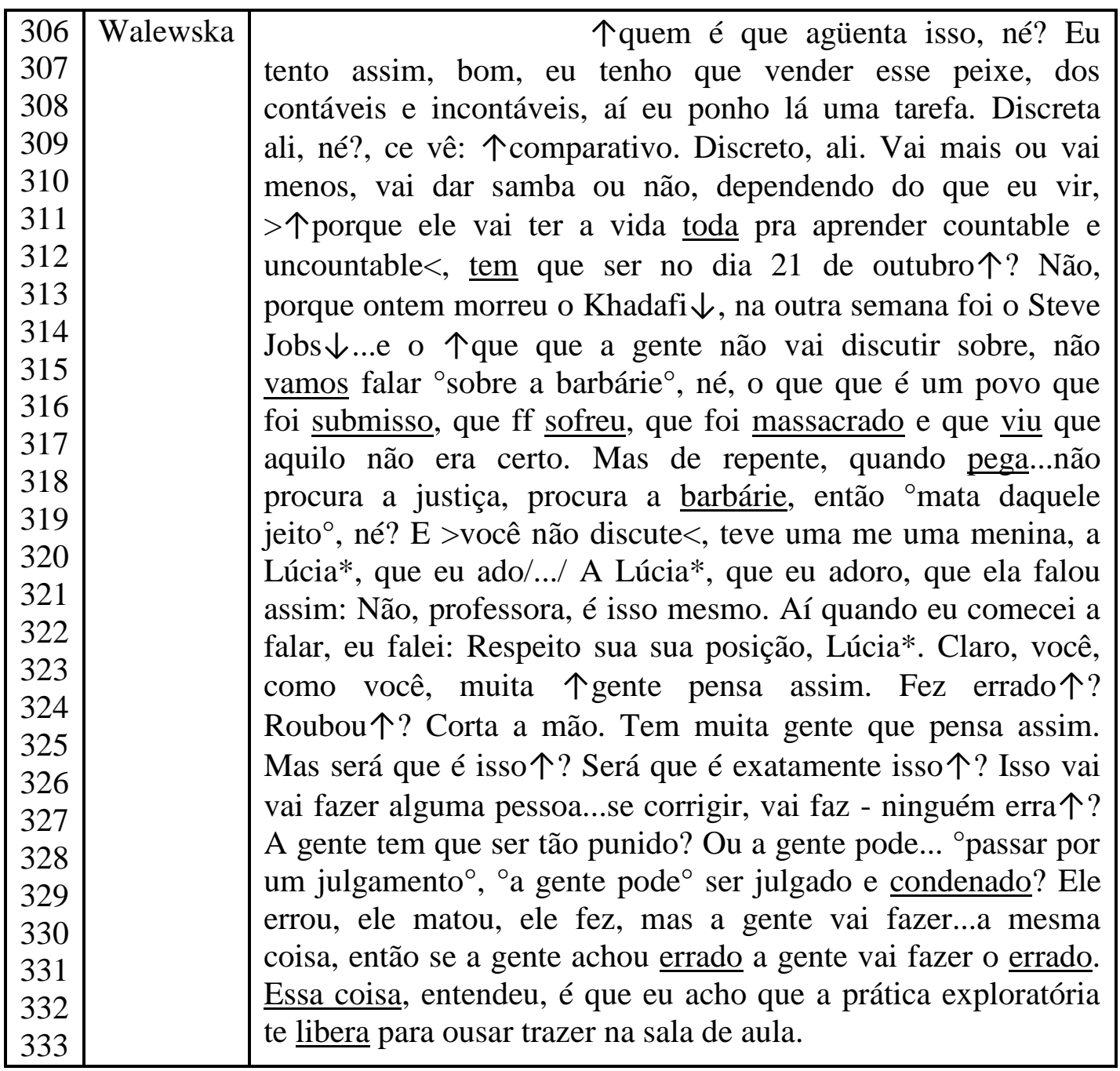

Nota-se, também, no fragmento, Walewska projetando sua identidade de professora atualizada e crítica, que questiona a atitude de um povo estrangeiro (Linhas 314 a 319), em uma situação de crise política. A ênfase nas palavras "submisso", "sofreu", "massacrado", "barbárie", parecem aumentar sua carga dramática, e as frases "sobre a barbárie" e "mata daquele jeito", ditas de forma lenta, também contribuem para chamar atenção do ouvinte para a crítica da professora aos acontecimentos.

\footnotetext{
${ }^{46}$ Nas linhas seguintes às citadas, a professora propõe alguns puzzles relativos ao caso Khadafi.
} 
A professora narra como o questionamento em sala de aula, sobre um fato da atualidade, estimulou a reflexão dos alunos e, ao invés de simplesmente acatar ou rechaçar a posição contrária de uma aluna, ofereceu mais perguntas para reflexão, procurando mostrar, desse modo, que as soluções para os dilemas, quando existem, nem sempre são simples, mas que é importante, sempre, buscar o entendimento (Princípio 2 da Prática Exploratória).

No início do trecho, nas linhas 306 a 310, a professora conta como inclui a matéria a ser dadas nas aulas, em meio às discussões e interesses diversos dos alunos. Ela se refere, nesse caso, ao Princípio 6, que defende a integração da Prática Exploratória com as práticas de sala de aula ou com outras práticas profissionais. Dessa maneira, a professora consegue "cumprir" o currículo escolar de maneira exploratória, sem sobrecarregar a si própria e os alunos, ao mudar um pouco o foco principal da aula (que não mais será a produtividade dos alunos) e aproveitar as oportunidades de discussão e reflexão, para lecionar a matéria. Esse discurso me parece coerente com as práticas adotadas pela professora em sala de aula, inclusive algumas que aqui serão vistas. Em minhas observações, no dia 09 de novembro, na turma 2 , relatei como os alunos se organizaram para terminar um trabalho sobre amizade iniciado na semana anterior. Apesar de eu não ter mencionado em minhas observações, o tópico gramatical subjacente ao tema era o passado simples, que foi trabalhado com a ajuda do dicionário, ao traduzir as frases dos alunos sobre como conheceram seus amigos do colégio. De qualquer maneira, o foco principal foi a discussão sobre amizade, bullying, tolerância, solidariedade. Consequentemente, para falarmos sobre o tópico em inglês, os alunos pesquisaram e aprenderam o passado simples.

Achei bastante curioso o fato de eu, como visitante, ter me fixado tanto no tema da amizade que não anotei o tópico gramatical da aula. Especialmente, porque eu e a professora conversamos sobre essa aula por e-mail e eu sugeri algumas atividades, que foram inclusive adotadas por ela. Acho que isso mostra meu envolvimento com a temática, que eu considero mais interessante que o ponto gramatical. Imagino que para os alunos, que não sabiam do objetivo curricular da professora com atividade proposta, a aula tenha sido apenas um debate gostoso sobre amizade e seus desdobramentos, com uma aprendizagem 
incidental de inglês, e ensinamentos valiosos para as relações sociais ao longo da vida.

Neste trecho, acredito que Walewska projeta não só uma identidade de professora exploratória, uma identidade de professora reflexiva, diplomática, apaziguadora, ao oferecer uma análise mais cautelosa da situação discutida em sala de aula (linhas 322 a 330).

Prosseguindo com a análise do Trecho 9:

\section{Quadro 16- Entrevista, Trecho 9}

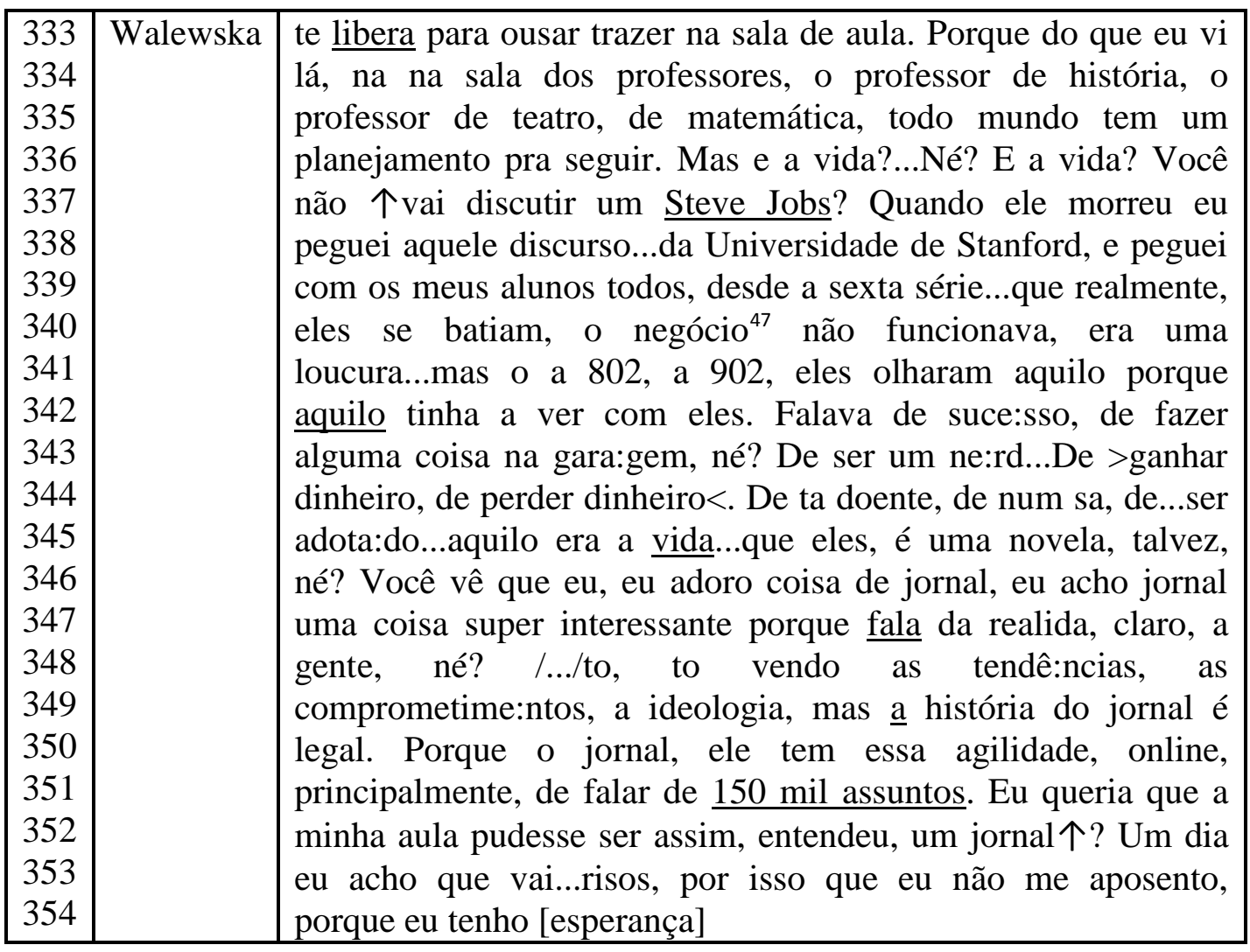

Nesse trecho, Walewska reforça a importância de se trazer para a sala de aula a vida exterior, mencionando o Steve Jobs, na linha 337, e fala de como um discurso do Steve Jobs mostrado em sala de aula foi significativo para os alunos, por ser real (1.338 a 345).

Walewska projeta fortemente sua identidade de professora nesse trecho. Quando ela fala da dificuldade em lidar com o equipamento para passar o vídeo

\footnotetext{
${ }^{47} \mathrm{O}$ "negócio" que não funcionava era o data show.
} 
“o negócio não funcionava" (1.340), da agitação dos alunos na hora "eles se batiam" (1. 340), ela se mostra como uma professora como tantas outras, que passa pelas mesmas situações e tem que lidar com o mesmo tipo de dificuldade. Apesar dos empecilhos naturais em uma sala de aula, Walewska ainda se mostra como uma profissional esperançosa, apaixonada pelo que faz (1. 353 a 354).

O sétimo Princípio da Prática Exploratória diz: "Fazer com que o trabalho para o entendimento e a integração sejam contínuos". Ao incentivar as discussões sobre os acontecimentos nacionais e internacionais e a integração dos mesmos ao currículo escolar, ao defender a importância de se suscitar tais debates, também defende-se que tal postura seja contínua, pois os eventos não param de ocorrer, e é de suma importância que eles sejam discutidos no âmbito escolar, formando-se assim cidadãos engajados e politizados. A continuidade é essencial para um professor exploratório, é essencial também na postura do professor transformador idealizado por Paulo Freire. Trabalhar a reflexão e o debate deve ser um exercício diário, e não uma atividade eventual. Nas linhas 333 a 336, quando a professora sinaliza a importância de estarmos sempre atentos às mudanças e acontecimentos importantes que ocorrem à nossa volta, e os integremos ao nosso cotidiano escolar, pois é assim que se formarão cidadãos conscientes, alunos exploratórios e profissionais transformadores, ela invoca esse Princípio.

A passagem a seguir possui um trecho que ilustra bem as Proposições da PE:

Quadro 17- Entrevista, Trecho 10

\begin{tabular}{|c|c|c|}
\hline $\begin{array}{l}364 \\
365 \\
366\end{array}$ & Vanessa & $\begin{array}{l}\text { Precisa ver tudo? Será que a gente pre, será que precisa } \\
\text { mesmo } \uparrow \text { ? } \\
\quad[\text { Será que isso...] }\end{array}$ \\
\hline $\begin{array}{l}367 \\
368 \\
\end{array}$ & Walewska & $\begin{array}{l}\text { A gen[te não ace], não abre todas as notícias, você len, ah, isso } \\
\text { aqui me interessa, [eu vou viajar] }\end{array}$ \\
\hline 369 & Vanessa & [será que] \\
\hline $\begin{array}{l}370 \\
371 \\
372 \\
373 \\
374 \\
375 \\
376 \\
377 \\
378\end{array}$ & Walewska & $\begin{array}{l}\text { Eu vou viajar, quero ver, eu não vou viajar, então não vou } \\
\text { ver } \downarrow \text {...né? e isso eu acho, até me:smo, né, nessa esco::la, } \\
\text { assim, como eu acho que seria uma escola...assim, gostosa, } \\
\text { né...eh o aluno poderia escolher...como é que ele vai } \\
>\text { trabalhar, agora<, operacionalizar isso, nem sempre é fácil } \\
\text { porque envolve, né, trocentas coisas...mas eu acho que você } \\
\text { ousar na medida do que faz é você também alimentar o prazer } \\
\text { de trabalhar, o prazer de viver, né? Porque uma das coisas que } \\
\text { a gente lo::go descobriu com os alunos...é que } \uparrow \text { a vida deles é: }\end{array}$ \\
\hline
\end{tabular}




\begin{tabular}{|c|c|}
\hline $\begin{array}{l}379 \\
380 \\
381 \\
382 \\
383 \\
384 \\
385 \\
386 \\
387 \\
388 \\
389\end{array}$ & $\begin{array}{l}\text { aquela. Eles passam to:dos, e, não sei quanto tempo, todos os } \\
\text { dias, de segunda a sexta-feira então eles tão vivendo ali, o } \\
\text { professor também. Eh, às vezes tem gente que fala: Ah, eh, } \\
\text { nós vamos sair, e tá proibido falar de aluno. 个Como ce vai } \\
\text { conseguir, né? É muito...cê não tem que falar só de aluno, mas } \\
\text { ele faz parte da tua vida, você tá num grupo que vive, vive } \\
\text { vivencia a mesma coisa, então não dá pra você proibir esse } \\
\text { assunto, ou então gente que fala: ai, eu tenho vida fora da } \\
\text { escola...e dentro também, deveria ter, né? Eu tenho uma vida } \\
\text { fora da escola, e dentro da escola você faz o que? (Risos) } \\
\text { Vegeta? }\end{array}$ \\
\hline
\end{tabular}

Nas linhas 372 a 377, Walewska, enfatizando a palavra "escolher", mostra a importância de criar oportunidades para que o aluno exerça sua autonomia e independência (Proposição 1: alunos são indivíduos únicos que aprendem e se desenvolvem melhor em sua própria idiossincrasia). Isso significa enxergar seu aluno como um indivíduo capaz de ser responsável pelo seu próprio aprendizado (Proposição 3), de tomar decisões (Proposição 4), em grupo ou sozinho. As Proposições da PE ilustram essa visão do aluno autônomo (Proposição 5: alunos são capazes de se desenvolverem como praticantes do próprio aprendizado), que contrasta com a visão do aluno dependente do professor, robotizado, que limita-se a absorver/memorizar o conteúdo aprendido, e que o sistema educacional atual se esforça em reproduzir, segundo Gaiarsa.

Ao conversarmos sobre o desejo da Walewska de querer que sua sala de aula fosse como um jornal, com vários assuntos atuais, as sobreposições cooperativas mostram como nossas ideias estavam alinhadas. Walewska, ao dizer que é necessário ousar no que se faz (ênfase na palavra “ousar", 1.376), e ter prazer no trabalho e na vida (linhas 375 a 381), com ênfase na palavra "prazer", projeta assim sua identidade de professora engajada e, de certa maneira, transgressora (lembrando que Walewska considera a Prática Exploratória uma filosofia transgressora, como se discutiu nas linhas 86 a 97, Conversa 2, Trecho 2).

Mais adiante, nas linhas 382 a 387, ainda no Trecho 10 da Entrevista, Walewska mostra um tom de indignação com comentários ouvidos na escola, em uma ocasião de confraternização entre os funcionários. Nesse episódio, ela projeta sua identidade de profissional, adulta, que sai para divertir-se com seus colegas de 
trabalho, mas mostra também a força de sua identidade como professora exploratória, apaixonada pelo que faz, e por isso mesmo considera impossível excluir os alunos de sua conversa, já que eles fazem parte da sua vida e, portanto, de certa maneira, são sua vida. No final dessa passagem ela confere um tom jocoso ao comentário, modificando um pouco o enquadre, ao dizer: "Eu tenho uma vida fora da escola, e dentro da escola você faz o que? (risos) vegeta?". A indignação e o tom jocoso mostram a maneira como Walewska interpretou os comentários dos colegas, o que projeta uma identidade de defensora de seus ideais. Entendo que essa afirmação poderia ser interpretada de duas maneiras. A primeira sendo: "Eu tenho uma vida fora da escola", significando que, além de uma vida dentro da escola, a pessoa também possui uma vida fora da escola. A segunda interpretação possível seria: "Eu tenho uma vida fora da escola", significando que dentro da escola não há vida. Claro que eu não sei qual foi a entonação usada pelo declarante ao fazer essa afirmação, mas Walewska interpretou-a da segunda forma, e essa interpretação mostra o quão forte é a Walewska professora, educadora, apaixonada; pois ela, imediatamente se posicionou em defesa de seu modo de enxergar a comunidade escolar.

Acredito que essa necessidade de "ousar" na sala de aula é observada nas aulas da professora. $\mathrm{Na}$ aula do dia 09 de setembro de 2011, na turma 2, ao realizar uma pesquisa para um trabalho, a professora, já sabendo que os alunos demandariam de nós bastante auxílio, estabeleceu um "balcão de informações", para onde os alunos deveriam dirigir-se se quisessem fazer uma pergunta. A professora modificou, dessa maneira, a dinâmica da sala de aula, ousou, com o objetivo de fazê-los agir de forma mais autônoma, proativa, e incentivando-os a serem responsáveis pelo seu próprio aprendizado (se eu quero alguma coisa, devo fazer um movimento: de ir buscar, procurar, perguntar). Além de essa prática refletir a escolha da professora em se permitir ousar, também reflete as Proposições da Prática Exploratória comentadas incialmente, ao empoderar os estudantes com as ferramentas necessárias à sua própria aprendizagem.

A próxima passagem a ser analisada mostra como a professora integra a Prática Exploratória à sua vida, corroborando nossa visão da Prática Exploratória como uma filosofia de vida, que não deve, portanto, ficar confinada aos muros 
acadêmicos e escolares. Através de seu depoimento, Walewska mostra como a Prática Exploratória mudou sua atitude com relação a vários outros aspectos da sua vida, e não só o profissional.

\section{Quadro 18- Entrevista, Trecho 13}

\begin{tabular}{|c|c|c|}
\hline 474 & Vanessa & [A ditadura, né? A repressão.] \\
\hline 475 & \multirow[t]{39}{*}{ Walewska } & [É...mas então], eram os os caras, os espiões, do governo, que \\
\hline 476 & & assistiam, então você sabia, você ia pra aula da Moema \\
\hline 477 & & Toscano e tal...era o máximo, né? Essa vida me encantava, \\
\hline 478 & & não tanto os livros. Né, não tanto, eu colava nas provas \\
\hline 479 & & ${ }^{\circ}$ alucinadamente $^{\circ}$. Eu não entendia $\uparrow$, eu tinha feito Normal $\uparrow$, \\
\hline 480 & & eu não $\uparrow$ tinha fundamento de nada. Então...esse lado assim....a \\
\hline 481 & & transgressão, sempre me encantou. A Prática Exploratória...de \\
\hline 482 & & certa forma, destampou isso e me fez ver que essas \\
\hline 483 & & transgressões eram $\uparrow$ interessantes...por isso eu buscava os \\
\hline 484 & & anjos...né? Porque eu não queria a transgressão. Porque eu \\
\hline 485 & & não fui criada na transgressão. Mas eu me apaixonei pela \\
\hline 486 & & transgressão. Então eu me encantei pelos fantasminhas, os \\
\hline 487 & & diabos eram muito mais interessantes que os anjos...mas isso \\
\hline 488 & & tudo, né...em mim, era tudo misturado. E na vida também $\uparrow$. \\
\hline 489 & & Eh o ouvir o outro...que é fundamental na Prática \\
\hline 490 & & Exploratória porque você vai aprender com o outro, então \\
\hline 491 & & você tem que ouvir $\downarrow$, vocês dois vão crescer juntos, então eu \\
\hline 492 & & tenho que ouvir o que você quer dizer $\uparrow$, não importa se você \\
\hline 493 & & é aluna, né...isso foi importante, numa época...assim, né...se \\
\hline 494 & & eu for...contextualizar, se eu for deixar uma coisa, \\
\hline $\begin{array}{l}495 \\
496\end{array}$ & & eh...fechada. Eh::: uma época em que eu tive que conviver \\
\hline 490 & & com acompanhantes, que cuidavam da minha mãe...né? Eu \\
\hline 491 & & tinha um quadro de uma mãe...eh...com Alzheimer, cinco \\
\hline 499 & & cuidadores, mais o pessoal de...de final de semana, folguistas, \\
\hline 500 & & que eu consegui trabalhar \\
\hline 501 & & les, entendendo. Aí eu entendi \\
\hline 502 & & $\begin{array}{l}\text { que eu tinha uma empregada que tinha sete filhos . Como e } \\
\text { que você tem sete filhos...trabalha...esses sete filhos, no início }\end{array}$ \\
\hline 503 & & eu nem sabia...os menores ficavam em casa, trancados, até a \\
\hline $\begin{array}{l}504 \\
505\end{array}$ & & hora da mais velha ${ }^{\circ}$ voltar da escola...abrir a porta e levar pra \\
\hline $\begin{array}{l}505 \\
506\end{array}$ & & escola $^{\circ} . .$. e aí eu fui começando a ouvir aquilo, e aquilo foi \\
\hline 507 & & importante pra mim, >não, isso não pod, essa situação eu não \\
\hline 508 & & quero<, vamos resolver isso? >Que que pod, ah eu preciso<, \\
\hline 509 & & pra tomar conta, não pode, $n$ \\
\hline 510 & & eu tenho certeza, Vanessa, que...se isso tivesse acontecido \\
\hline 511 & & antes da Prática Exploratória >eu não tava nem querendo \\
\hline $\begin{array}{l}512 \\
513\end{array}$ & & saber<...era um trabalho, era uma coisa profissional...ent \\
\hline $\begin{array}{l}513 \\
514\end{array}$ & & ${ }^{\circ}$ essas moças todas ${ }^{\circ}$ me ensinaram muito. $\mathrm{O}$ que que é a mãe \\
\hline $\begin{array}{l}514 \\
515\end{array}$ & & dos meus alunos. Porque a mãe dos meus alunos, não é $\uparrow$ a \\
\hline 516 & & minha, não é \\
\hline
\end{tabular}




\begin{tabular}{|c|c|}
\hline $\begin{array}{l}517 \\
518 \\
519 \\
520 \\
521 \\
522\end{array}$ & $\begin{array}{l}\text { tive...provavelmente a mãe que você teve. É essa } \uparrow \text { mãe que } \\
\text { tem sete filhos. Como é que é isso } \uparrow \text { ? Como é que } \uparrow \text { mais } \\
\text { velho toma conta do menor? Ah, isso na minha sala } \\
\text { também } \downarrow \text {. Então entender as pessoas e aprender > quantas } \\
\text { coisas elas me ensinaram, até coisas práticas, eu não sabia } \\
\text { fritar< uma um bife... }\end{array}$ \\
\hline
\end{tabular}

Essa passagem mostra, em diversos momentos, reflexões da Walewska sobre como a Prática Exploratória influenciou sua vida além da sala de aula, em como o exercício diário dos Princípios e Proposições da Prática Exploratória contribuiu para que houvesse uma mudança de perspectiva diante de situações rotineiras (linhas 481 a 483, 489 a 493, 510 a 513).

Analisando-se as linhas 514 a 516, nas quais a professora entrevistada afirma que a mãe dos seus alunos não é a mesma mãe que elas ("elas" se refere à própria Walewska e à mim) tiveram, percebe-se a busca de uma identificação. Aqui, Walewska mostra para Vanessa que ambas fazem parte de uma realidade social diferente da realidade em que vivem os alunos da Walewska. Desse modo, ao chamar-me pelo nome, na linha anterior, Walewska provavelmente busca uma maior aproximação entre as duas, encurtando assim a distância sugerida pelo teor da conversa. Assim, há uma convergência de identidades sociais entre nós duas como participantes da interação.

Esse mesmo trecho apresenta Walewska projetando identidades que até então não haviam sido mostradas. Logo no início (1. 475 a 480), Walewska projeta uma identidade de jovem estudante, ao narrar a sua vida de estudante universitária na época da ditadura. Ela conta como ela se encantava pelas aulas ministradas por professores que eram considerados revolucionários, como ela "colava" nos exames e como, nessa época, ela se "apaixonou pela transgressão". Logo após esse relato, vemos Walewska retornar novamente à sua identidade de professora exploratória, explicando como a Prática Exploratória a ajudou a encarar a transgressão como uma característica do ser humano, sendo mesmo necessária ao nosso desenvolvimento. Ela, então, se encanta pelos alunos "diabinhos" e alunos "fantasminhas camaradas", e descobre a importância de se ouvir o próximo. 
Nas linhas 495 a 500 Walewska projeta sua identidade de filha, ao narrar os cuidados que teve que ter com sua mãe adoecida, e sua identidade de dona de casa, ao administrar um lar, e empregados, em uma ocasião específica. Ela conta como o diálogo e o entendimento mútuo entre as pessoas envolvidas (ela, os empregados, o marido e a mãe) foram importantes para que ela conseguisse administrar tudo de maneira eficaz. Nessa ocasião, ela conta como se sensibilizou com a situação de uma de suas funcionárias, que possuía muitos filhos e tinha que deixá-los trancados em casa enquanto trabalhava. Nesse momento, acredito que Walewska se mostrou também uma humanista, uma pessoa verdadeiramente preocupada com o bem-estar do ser humano. Interessante a afirmação da professora (1. 510 a 512): "e eu tenho certeza, Vanessa, que...se isso tivesse acontecido antes da Prática Exploratória, > eu não tava nem querendo saber<...", ou seja, a professora atribui à PE a sua mudança de perspectiva, a sua diferente maneira de lidar com situações rotineiras. Por último, Walewska também se projeta como aprendiz, ao afirmar, nas linhas 520 e 521: “entender as pessoas e aprender>quantas coisas elas me ensinaram, (...)". Ou seja, Walewska afirma que ela, ao procurar entender e apoiar as pessoas que trabalhavam com ela nessa ocasião, também aprendeu muito.

Sob a ótica exploratória, o trecho selecionado mostra-se distinto dos analisados anteriormente, pois nele a professora fala como ela incluiu a Prática Exploratória em uma situação de sua vida que não estava conectada diretamente à sua prática profissional (sala de aula), corroborando assim nossa visão da Prática Exploratória como uma filosofia de vida.

Nas linhas 489 a 513, Walewska narra como a adoção dos Princípios da Prática Exploratória refletiu em sua vida doméstica, na situação específica de ter que lidar diretamente com um quadro relativamente grande de funcionários, sob sua coordenação. Ela conta como o "saber ouvir" contribuiu positivamente para todos os envolvidos naquela situação (incluindo, obviamente, ela própria), aumentando a qualidade de vida daquela pequena comunidade. Nessa situação, o "saber ouvir", quer dizer, saber prestar atenção no que o outro diz, refletir sobre isso e procurar estudar, conjuntamente, as questões suscitadas, na verdade é a junção todos os Princípios da Prática Exploratória. E desse modo, todos aprenderam algo, todos ficaram satisfeitos, e Walewska mesmo admite que, antes 
da Prática Exploratória, ela não teria enxergado a situação sob essa perspectiva. Até porque, era uma relação de trabalho que poderia ser encarada de maneira extremamente objetiva. E estamos todos acostumados a separar a situação de trabalho de outras situações de nossa vida diária (como se uma não influenciasse, direta ou indiretamente, positiva ou negativamente, na outra).

Percebo então, que Walewska exterioriza algumas crenças do grupo da Prática Exploratória, em sua fala. Não quero dizer que ela fala em nome do grupo, mas que ela se projeta identitariamente como membro do grupo. É a voz de um membro para ajudar a expressar quem somos (Allwright \& Hanks, p.217). Assim, entendo que é legítimo concluir que, durante seus relatos, ao descrever suas práticas e crenças, a professora fala "em nome de um 'nós', não de um 'eu" (Goffman, p134, v. p. 42).

Com relação ao padrão identificado na mudança de turnos, creio que, através da análise dos trechos selecionados ${ }^{48}$, observei poucas mudanças de turno e, nos casos em que houve, ocorreram algumas sobreposições cooperativas que, como já vimos, são, de acordo com Tannen, características do gênero feminino, constroem uma interação de falantes de alto envolvimento, e, nesse caso especifico, mostram o constante alinhamento de nossas ideias, essencial para a projeção das identidades de Walewska e para o meu processo de convencimento.

Durante a análise dos enquadres, notei a frequente alternância entre os enquadres de entrevista e o de enquadre entre amigas, o que sugere que eu, apesar de tentar me colocar no papel de pesquisadora, não consegui me manter nesse papel sem esforço, frequentemente expondo também minha opinião, e assim, gerando um maior número de sobreposições, o que descaracteriza uma entrevista formal, e se aproxima mais de uma conversa informal entre amigas. Walewska também buscou, em seu discurso, aspectos que nos aproximavam como professoras, praticantes, estudantes, membros de uma mesma classe social, o que contribuiu também para o enquadre de conversa entre amigas. Além disso, por diversas vezes identifiquei um enquadre reflexivo. Entretanto, agora, penso que a

\footnotetext{
48 A transcrição da conversa na íntegra apresenta um maior número de sobreposições e, quiçá, através da análise dessas, poder-se-á identificar algum padrão outro. Entretanto, selecionei os trechos baseada na sua interpretação à luz da PE, que é o foco de minha pesquisa, e, portanto, fugiria do escopo desse trabalho uma análise mais detalhada talvez de todas as sobreposições ocorridas durante a conversa.
} 
reflexão esteve presente durante toda a conversa, o que sugere então que o enquadre reflexivo, apesar de mais evidente em certos momentos, esteve subjacente durante todas as interações, tanto na Entrevista quanto a Conversa.

Walewska projetou identidades variadas durante nossa conversa: jovem estudante, jovem professora, professora exploratória, educadora reflexiva, transformadora, engajada, cidadã brasileira (contribuinte), professora maternal, diplomática e apaziguadora, filha, dona-de-casa, empregadora / administradora do lar e aprendiz. Em meio a essas diversas nuances, consegui perceber os Princípios e Proposições norteadores da Prática Exploratória em sua prática diária (através das observações de aula), em suas reflexões (através dos $e$-mails, dos comentários nos diários e das entrevistas).

\section{2 As anotações sobre as aulas}

Nesta seção reflito sobre minhas notas de campo, ou seja, o diário que compus à medida que assistia às aulas de Walewska.

Relendo o meu diário de anotações, algumas passagens me chamaram a atenção, seja por terem me surpreendido, seja por eu ter achado que não ficaram bastante claras, ou mesmo por considerar que elas mereçam uma atenção maior, muito embora eu não as tenha mencionado na análise acima. Por isso, escolhi escrever mais essa pequena seção.

Durante todo o diário, eu me refiro à Walewska como "a professora", o que sugere um distanciamento que, na sala de aula, não existia. Eu era observadora-participante, e não apenas uma observadora, e nós conversávamos e interagíamos durante as aulas todo o tempo. Refletindo sobre esse aspecto com minha orientadora, surgiu a interpretação de que, talvez, esse fato tenha ocorrido por eu já ter sido mentora de um curso de inglês, e a função inclui observação da aula dos professores de maneira mais objetiva. Além disso, eu também fiz um 
curso na Inglaterra (Celta course ${ }^{49}$ ) que tinha observações de aula diárias, durante um mês. O fato de eu ter me referido à Walewska de forma mais distante e objetiva, portanto, pode ter sido devido ao fato de eu estar "condicionada" a assim proceder, devido a experiências anteriores. Claro que isso é apenas uma possibilidade.

Outras questões surgiram nas aulas do dia 02 de setembro de 2012, tanto na Turma 1 quanto na Turma 2. Nas anotações sobre a Turma 1, página 130, eu disse que a atividade não me pareceu exploratória pois não havia partido de um puzzle dos próprios alunos. Mas a atividade nem sempre precisa surgir de puzzles, eles também podem ser uma consequência do trabalho para entender. O que eu quis dizer é que a maioria dos alunos não parecia interessada em pesquisar. De qualquer maneira, também escrevi, ao tentar interpretar o comportamento de Walewska:

\begin{abstract}
Entretanto, pode ser que a professora tenha feito isso de modo a despertar nos alunos a consciência de que havia a possibilidade de outras respostas para o "mistério do mural", como a professora chamou. Mas, como eu disse anteriormente, para os alunos não parecia haver mistério.
\end{abstract}

Walewska, em suas anotações posteriores, confirmou que ela quis aproveitar a questão para discussão, ainda que a questão tivesse partido dela, projetando, assim, mais uma vez, a sua identidade de professora exploratória e profissional transformadora.

Mais adiante, nas observações da Turma 2, considero que os dois últimos parágrafos (p. 131 - 132) merecem uma maior atenção. Após escrever sobre a atividade em grupos proposta por Walewska, eu acrescentei uma observação:

P.S. Houve um grupo que chegou depois de uns 15 minutos de a aula ter se iniciado. Não ficaram muito engajados durante a atividade. Era um grupo grande, uns sete alunos. A professora tentou dividir o grupo mas, na prática, apenas dois alunos (os que estavam responsáveis pela folha de papel que deveria ser entregue à professora), efetivamente pareciam se dedicar.

\footnotetext{
${ }^{49}$ Curso para obter o Certificado de Ensino da Língua Inglesa para Adultos (Certificate of English Language Teaching to Adults)
} 
Percebo, pelas minhas palavras, que o fato de um determinado grupo não ter se concentrado nas atividades chamou a minha atenção, e, inclusive, me causou desconforto. Em nenhum momento eu questionei se os alunos, ainda que aparentemente estivessem desatentos, estavam aprendendo, como a própria Walewska já descobriu quando realizou a atividade dos Anjos e Vampiros há alguns anos atrás. Transcrevo algumas partes do e-mail da Walewska, constante do ANEXO III:

E os dados que colhi foram: durante o exercício os alunos conversavam, jogavam, comiam, ouviam 'walkman'; durante o teste eles estavam concentrados, calmos e atentos.

No entanto as notas do teste foram boas e eu não podia dizer que os alunos, apesar do jeito informal e relaxado de assistir às aulas, não tinham aprendido nada. (...)

Levei meus alunos ao cinema para assistir o filme Policarpo Quaresma, parte do projeto "Indo ao Cinema". Pude então observar que no escurinho do cinema eles não se "comportavam": falavam alto, ficavam em pé, iam ao banheiro, comiam... se comportavam do mesmo modo que agiam nas minhas aulas. Eu saí com a certeza de que eles não tinham prestado a mínima atenção. Para minha surpresa, o grupo do projeto encarregado da discussão veio à minha sala e os meus alunos não apenas sabiam a estória como fizeram comentários pertinentes e críticos comparando os políticos da época aos políticos de hoje. Como poderia eu negar que eles aprenderam - e muito bem- a lição ensinada?

E algo começava a me inquietar: "Por que eu não conseguia entender e aceitar a maneira que meus alunos tinham de participar nas minhas aulas?"

Talvez devido a essa experiência passada, Walewska sequer mencionou a minha observação de "mau-comportamento" ao realizar suas anotações. Muito pelo contrário, ela focou no lado humano, no lado positivo da sua aula e de seus alunos:

Os relatos foram lindos, bem escritos e eu me emocionei ao lê-los. Muitos alunos se conheciam desde pequenos, uma vida juntos; outros chegaram mais tarde e todos tiveram importância na vida de todos. Os professores também deram depoimentos bonitos; as amizades que perduram até hoje, as amizades da escola que vão além da escola. As situações de sala de aula: as injustiças que levam uns a defenderem os outros e até amigo oculto organizado pela professora, que fez com que alunos que não se falassem se tornassem amigos para sempre... Riqueza de material!!!! 
Acho que eu, como a Walewska naquele tempo, ainda espero que os alunos ainda se comportem como anjos. É necessária uma mudança de paradigma, para que possamos acreditar no potencial dos alunos e respeitar seu jeito de aprender. Afinal, a Proposição 4 diz que os aprendizes são capazes de tomar decisões independentemente, e isso inclui a decisão de como eles irão aprender. E, se a decisão é deles, não é justo que julguemos se estão aprendendo ou não, apenas porque não se comportam da maneira que esperamos que se comportassem.

Apesar desse episódio, não posso negar que os alunos sempre demonstraram um carinho e um respeito muito grandes pela Walewska, conforme demonstra a anotação do dia 26 de agosto, na turma 2 (p. 127-128):

Um grupo de meninos lá atrás parecia ignorar a presença da professora, e estavam sentados displicentemente, jogando cartas. Walewska se dirigiu a eles e pediu que eles fizessem a atividade, e então eles começaram a fazer, utilizando o celular para procurar a tradução das palavras (com o Google translator). Achei interessante como tudo isso se deu: a professora, ao invés de lhes dar uma "bronca" em voz alta, se dirigiu até o grupo após todos os demais já terem iniciado o trabalho e, com a voz mansa e baixa que lhe é característica, pediu-lhes para que guardassem o jogo. Os três meninos prontamente atenderam ao pedido da professora e se engajaram no trabalho até o fim da aula. Achei fantástico o cuidado que a professora teve de não expor os alunos, e também o fato de os alunos não oferecerem resistência ao pedido da professora, como também é muito comum.

Os alunos demonstram, também, engajamento, apesar do jeito displicente de se comportarem, como na aula Turma 2, na aula do dia 09 de setembro de 2011:

A última tarefa era um mini-pôster e quase todos os grupos concluíram a tarefa e colocaram no mural. Poucos grupos que não terminaram não queriam sair para o recreio sem terminar, queriam continuar fazendo. Infelizmente o Inspetor teve que retirá-los de sala pois ele deve trancar a sala nesse momento. Isso é um absurdo: tem que trancar e expulsar os alunos que querem trabalhar, alguém entende??? Interessante: alunos VERDADEIRAMENTE engajados, que preferem ficar em sala e finalizar o trabalho ao invés de ir para o Recreio.

Nessas duas ocasiões vemos como Walewska logra êxito na sua empreitada de formar seus alunos buscando a eficiência do entendimento, 
utilizando os Princípios e Proposições da Prática Exploratória em sua prática diária. Na sua tentativa de entender os alunos, ela não os pressiona com falsas expectativas ou cobranças exageradas (normalmente resultado de um foco exagerado na eficiência do resultado), e, ao mesmo tempo, aplica prova, ensina a matéria estipulada no currículo, faz com que os alunos façam os exercícios e usem os dicionários, se engajem, a respeitem e pensem criticamente sobre a realidade que os cerca.

Outro ponto que eu considero interessante e que não foi abordado nesse trabalho são as avaliações. Eu quase não fiz anotações no dia da avaliação, a não ser o fato de a prova ter sido em dupla, o que é interessante, pois demonstra a crença da professora no trabalho em grupo, no colegiado, no envolvimento de todos e na união de todos. A própria professora, em resposta às minhas anotações, já expressou sua opinião sobre essa prática (ver p. 132-133), “Trabalhar em grupo é tão importante... Como gerenciar as tarefas? O tempo? Onde pesquisar? Quem faz? São tantas coisas a considerar... Eu apoio!!!!”.

Nada mais foi mencionado sobre esse dia além disso. E Walewska, ao se deparar com essas anotações, admitiu que também não se recordava da prova, e suscitou questões que eu considero bastante instigantes, apesar de elas não terem sido objeto de um estudo mais aprofundado:

Eu não me lembro do dia. Mas é interessante porque a prova faz parte. Por que não há anotações??? Como foi feita? Como a professora trabalhou esse momento? E porque a professora não se lembra???? Ah, a eterna questão: a avaliação... os resultados / o produto/ os índices/ a meta. Será???

Será que nossa opinião sobre como as avaliações escolares são feitas, sobre as metas e índices a serem alcançados, nos fizeram diminuir a importância a esse momento? E porquê não valorizamos o que o momento da avaliação pode proporcionar, como o engajamento, a atenção e a concentração, que nem sempre estão presentes em outros dias de aula? Porquê não observar os alunos, como se comportam, perguntar-lhes o que pensam? Enfim, várias questões podem ser suscitadas a partir desse tópico, e eu escolhi ignorar todas elas naquele momento. 
Entretanto, deixo registrado esses meus "puzzles", e também os da Walewska, para que sejam investigados em um outro trabalho. 


\section{5 \\ Considerações Finais}

Nesse trabalho procurei mostrar a minha forte crença na importância do pensamento crítico para o desenvolvimento de uma sociedade consciente e socialmente engajada. Busquei, também, oferecer um estudo de caso que ilustra uma alternativa ao sistema educacional atual, através do oferecimento de outra perspectiva, que é a Prática Exploratória como filosofia de vida. Afinal, para que a sociedade se transforme, é necessária uma mudança em nosso sistema educacional, pois, como já foi dito, é impossível esperarmos resultados diferentes se continuamos com as mesmas ações.

A Prática Exploratória, como filosofia de vida, busca nortear nossas atitudes de modo que passemos a agir menos mecanicamente, para que tenhamos real consciência dos nossos atos, ou, ao menos, busquemos ter. No presente estudo, busquei entender, juntamente com Walewska, que é considerada um core member do grupo da Prática Exploratória no Rio de Janeiro, como é viver, em sala de aula e fora dela, tendo a Prática Exploratória como filosofia de vida, norteadora de nossas ações.

Lembro-me da confusão de sentimentos quando conheci a Prática Exploratória: ao mesmo tempo em que me maravilhei com o que vi e ouvi durante as reuniões, era incrédula com relação à viabilidade da proposta em nossa sociedade. Por isso, decidi procurar entender Walewska, professora considerada "ícone” por muitos integrantes do grupo da Prática Exploratória, por estar sempre engajada em atividades exploratórias e transparecer um amor e comprometimento com o seu papel social de professora transformadora, e que é, além de tudo isso, extremamente simpática e acessível. Será que ela efetivamente conseguia colocar em prática todos aqueles Princípios e Proposições, trabalhando em uma escola do município do Rio de Janeiro, com todas as já conhecidas dificuldades que o professor enfrenta nesse setor? 
Meu objetivo final foi o de entender essa professora, suas crenças, suas ideias, seu jeito de entender a sala de aula, seu jeito de ensinar e de viver. Ao final desse trabalho, após as leituras, reflexões, discussões e conversas, em conjunto com a professora Walewska Braga, percebi que o que fiz foi uma Prática Exploratória, pois a partir de uma questão minha iniciei essa "investigação" conjunta, buscando entendimentos particulares que, espero, possam servir de inspiração para outros leitores, ou mesmo ajudar no entendimento do que é a Prática Exploratória.

A Entrevista levou-me a buscar entender alguns aspectos da vida dessa profissional, e levou-a a relembrá-los, e, dessa maneira, logicamente, refletir novamente sobre eles. Nosso segundo encontro, a Conversa, foi baseado na Entrevista, onde buscamos esclarecer alguns pontos que considerávamos pouco claros. Descobrimos algumas vezes que o que Walewska quis dizer com determinada declaração não foi o que eu havia entendido. Graças a esse debate posterior, algumas dúvidas e tópicos foram esclarecidos. E, assim como na vida, antes de julgar, é sempre necessário buscar entender, sob o risco de se incorrer em pré-julgamentos precipitados e errôneos.

Tanto na Entrevista quanto na Conversa, Walewska demonstrou entusiasmo em relembrar momentos anteriores de sua carreira e sua vida, e satisfação por repensar alguns aspectos de sua prática para $2012^{50}$. Desse modo, entendo que tanto eu quanto Walewska construímos nossas identidades de pesquisadoras-praticantes, ao tentar refletir, conjuntamente, sobre o que foi dito. De maneira exploratória, buscamos co-construir nossos entendimentos sobre as práticas relatadas durante as conversas, nossas impressões e experiências pessoais. E assim é a pesquisa exploratória, não parasítica, em que todos saem com um entendimento a mais sobre si próprios, ou a situação em que se encontram.

Desenvolvendo a pesquisa, percebi que me ative muito mais, durante a observação das aulas, aos temas sociais e reflexivos abordados pela professora, do que ao conteúdo linguístico em si. Achei bastante curioso quando ela devolveu as minhas anotações comentadas e pontuou o tema gramatical subjacente em uma das aulas, que era o passado simples. Antes dessa aula sobre amizade e passado

\footnotetext{
${ }^{50}$ Trecho não transcrito do nosso segundo encontro.
} 
simples, conversamos por e-mail, trocamos ideias e eu dei algumas sugestões de atividades para que os alunos desenvolvessem o tema de amizade juntamente com o tópico gramatical. Os alunos, ao desenvolverem a atividade, receberam uma folha que continha exercícios estruturais como passar os verbos para o passado simples em inglês, por exemplo. Claro que os exercícios tinham como tema subjacente a amizade, mas os exercícios eram estruturais. Entretanto, nas minhas notas durante a aula, eu sequer mencionei a gramática. Acho que isso sugere um grande nível de integração entre o conteúdo linguístico e o trabalho reflexivo, de acordo com o Princípio 6 - que diz que devemos tentar integrar o trabalho da sala de aula com as práticas exploratórias.

O foco da pesquisa foi identificar os Princípios da Prática Exploratória na prática profissional diária de Walewska, bem como identificar se e como essa filosofia está presente em sua vida pessoal, extraclasse. A Análise da Conversa me ajudou a entender mais profundamente nossas interações, mostrando o ambiente cooperativo e o engajamento das duas participantes da interação, onde o "saber ouvir" esteve sempre presente, mostrando que os Princípios da Prática Exploratória também guiaram essa pesquisa, que foi, como dito anteriormente, a realização de uma APPE - Atividade Pedagógica com Potencial Exploratória -com uma questão que me intrigava: o porquê de Walewska Braga ser considerada um "ícone" do grupo da Prática Exploratória, e o que ela faz no seu dia a dia?

Reproduzirei, aqui, passagens de nossa comunicação via e-mail do dia 26 de setembro de $2011^{51}$, quando Walewska me enviou um relato sobre como os alunos avaliaram o trabalho do terceiro bimestre, que acho que retoma alguns pontos importantes dessa dissertação:

\section{Vanessa querida,}

Estou mandando os comentários dos meus queridos sobre o bimestre. E você muito contribuiu com o trabalho que todos fizemos. Acho que você percebeu como os danadinhos nos envolvem, é um carinho aqui, um elogio ali, um segredinho... Pois foi o que você fez em todas as suas visitas (lembra quando você notou que a Luana* da Turma 2 não estava na aula?). Muito legal quando entendemos que TODOS são importantes, e cada qual do seu jeito contribui para que todos aprendam: isso é educar!

\footnotetext{
${ }^{51}$ E-mail na íntegra no ANEXO VI.
} 
E o que eles dizem??? Pois, veja vc, Vanessa querida: eles dizem que gostaram de trabalhar, que aprenderam, que foi legal!!!! Alunos de escola municipal, adolescentes... não são aqueles que não querem nada, não fazem nada, não têm jeito??????

Pois eu tenho você como testemunha!!! Quem vai acreditar que o Paulo* e o José* da Turma 2 deixaram as cartas de lado e pesquisaram (usaram o celular, e daí?) , fizeram mural, recortaram e colaram???? Como é que até agora não tínhamos percebido o talento do Mauro* da Turma 1 para o desenho, o menino é incrível!!! Ah, sim, o grupo do Renato*, Cauã* e etc... não fez os trabalhos, enrolou o tempo todo ( mas eu sei que estão LOUCOS, disputando as atenções da Mariana*, femme fatale, que nada quer com eles, mas estimula a disputa... adolescer não é fácil!!!) mas... na última hora se mexeu (a nota, a prova!!!) e eles quase conseguiram fazer tds as tarefas do bimestre! Quem vai acreditar que eles vinham atrás de mim para pedir os trabalhos que faltavam (ou que não fizeram no dia)?

Podem duvidar de tudo... mas eu não estou nem aí, eu tenho meus EP secrets...

Imagina como me senti ao ler que as aulas são alegres; que os trabalhos ajudaram os alunos a se enturmarem, que entrevistar os funcionários foi legal...Muito feliz, claro, mas o bom é ver que eles percebem tudo e... percebem que a professora acredita neles, e que se a sala de aula tem seus momentos not so good,tem tb os good moments, tem muito trabalho e isso é bom, tem gente aprendendo... E o humor??? E a alegria???

Ah, como eles trabalharam! Você viu, Vanessa! E eles sabem tudo: é muito trabalho mesmo, tenho que me segurar, mas vou me empolgando e quando vejo, tem inspetor na porta ou a saída deles atrasa... Tenho que rever isso mesmo! Eu estava achando isso e eles, zás, confirmaram.

E agora vamos ao último bimestre: é hora de trabalhar as apresentações para o grupo (gosto também que eles apresentem o que fazem nas turmas do primário). Aí nosso desafio: eles trabalham bastante, trocam as informações, as "respostas". Assim, meio escondido, 'cola' mesmo. E por que não reconhecer esse modo de aprender? Os trabalhos do mural fazem isso: o mural registra o que todos aprenderam, mas é frio, é parado, é descartável! Vamos trabalhar para que eles mostrem os trabalhos, comentem , troquem, partilhem... Bom sambinha pela frente!(...)

Nesse depoimento, percebemos como Walewska se engaja e vibra com as reações e conquistas dos alunos. Vemos que a professora ecoa novamente os Princípios e Proposições da Prática Exploratória, ao afirmar que todos são importantes e cada um contribui para o aprendizado de todos (Proposição 2, Princípios 3 e 4). Walewska também ressalta que os alunos ficaram felizes com as aulas, e entende que eles aprenderam não só a matéria, mas também habilidades sociais (os trabalhos ajudaram os alunos a se enturmarem, entrevistar os funcionários foi legal). Walewska projeta uma identidade de quem se preocupa 
com os alunos individualmente, ao citar o nome de alguns deles e suas características em seu relato, e de uma professora inovadora, receptiva a novas possibilidades, ao defender que a "cola" pode ser um meio de aprendizado também. Walewska reflete sobre seus alunos que, apesar de estigmatizados por serem alunos de uma escola municipal, são participativos e interessados. Acredito que a alternativa exploratória que Walewska buscou foi alcançada.

É claro que cada pessoa, ao analisar essas mesmas páginas, poderá chegar a entendimentos que não necessariamente vão coincidir com as minhas. Isso é esperado, como já se debateu anteriormente. Espero, entretanto, haver compartilhado, na medida do possível, minha interpretação da vida de uma profissional, filha, esposa, dona de casa e aprendiz exploratória. Espero, também, ter ajudado os leitores a entender a minha busca pessoal por melhor compreender a Prática Exploratória, através desse mergulho no universo exploratório da professora e companheira Walewska Braga, sem a qual nada disso seria possível. Assim, faço minhas as palavras de Walewska, na Conversa 2, Trecho 4, linha 244: “É complicado de explicar. Mas não é de entender". 


\section{6 Referências Bibliográficas}

ALLWRIGHT, D. Integrating training and development: the role of research. Unpublished. 1996a. Disponível em: <http://www.letras.pucrio.br/oldepcentre/readings/integrating\%20training\%20and\%20developmentin.ht ml> Acesso em: 09 fev. 2012.

Words fail me! Lancaster, 1996b, mimeo.

Planning for specific change in a context of endemic change: the role of understanding (a two-page unpublished monograph). 1998. Disponível em: $<$ http://www.letras.puc-rio.br/oldepcentre/readings/planned\%20specific\%20 change.htm> Acesso em: 05 jan. 2012.

The notion of progress in research on language teaching and learning. Lancaster, March. 2000.

Bringing classroom language learning to life. In: Pesquisas em discurso pedagógico. Vivenciando a escola. Volume 1, projeto IPEL Escola, novembro 2002. Publicação do IPEL - Instituto de Pesquisa e Ensino de Línguas da PUC-Rio, pp.37-67.

Why social science research needs to be practitioner research: arguments for "Exploratory Practice”. PUC - Rio. 2003a.

Exploratory Practice: rethinking practitioner research in language teaching. In: Language Teaching Research. v 7, number 2, May 2003b. p.113 141.

Planning for Understanding: A New Approach to the Problem of Method. In: Pesquisas em Discurso Pedagógico: Vivenciando a Escola. Rio de Janeiro, Instituto de Pesquisa e Ensino de Línguas, PUC-Rio, v.2, n.2003c. p. 724. 
ALLWRIGHT, D.; BAILEY, K. M. Focus on the Language Classroom. New York, Cambridge University. 1991.

ALLWRIGHT, D.; MILLER, I. K. Burnout and the Beginning Teacher. In: TARONE, E.; SONESON, D.; CHAMOT, A. U.; MAHAJAN A.; MALONE M. (Eds.). Expanding our horizons: Language teacher education in the 21 st century. Minneapolis: The Center for Advanced Research on Language Acquisition, no prelo.

ALLWRIGHT, D.; HANKS, J. The developing language learner. Palgrave, Macmillan. 2009.

ALVES, R.; DIMENSTEIN, G. Fomos maus alunos. Campinas, SP. Ed. Papirus.

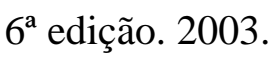

ALVES, R. Conversas sobre educação. Campinas, SP. Editora Versus. 2010.

ANTAKI, C.; DÍAZ, C. A análise da conversação e o estudo da interação social. In: IÑIGUEZ, L. (Orgs.). Manual de análise do discurso em ciências sociais. Cap. 4. Petrópolis, Ed. Vozes. 2004.

ARNOLD, J.; BROWN, D. A map of the terrain. In: ARNOLD, J. Affect in Language Learning. Introduction. United Kingdom, Cambridge University Press. 1999.

BAIÃO, J. C. Enquadres e alinhamentos na interação entre crianças em uma partida de "Jogo da Memória": a co-construção de identidades de gênero no contexto escolar. In: PEREIRA, M. G. D.; BASTOS, C. R. P.; PEREIRA, T. C. (Orgs.). Discursos sócio-culturais em interação. Rio de Janeiro: Ed. Garamond. 2009.

BAKHTIN, M. (Volochinov). Marxismo e filosofia da linguagem. Cap. 9: O Discurso de Outrem. Ed. Hucitec Annablume. São Paulo. 2002.

BARZIN, A. Dharma na Vida Diária. Disponível em: < http://www.berzinarchives.com/web/pt/archives/approaching_buddhism/introducti on/dharma_daily_life.html> Acesso em: 13 jan. 2013 
BIBIKOVA, A.; KOTELnIKOV, V. East versus West. Disponível em: $<$ http://www.1000ventures.com/business_guide/crosscuttings/cultures_east-westphylosophy.html> Acesso em: 17 jul. 2012.

BRAIT, B. Alguns pilares da arquitetura bakhtiniana. In: BRAIT, B. (Org.). Bakhtin Conceitos-Chave. Ed. Contexto. 2005.

BRAIT, B.; MELO, R. Enunciado/enunciado concreto/enunciação. In: BRAIT, B. (Org.). Bakhtin Conceitos-Chave. Ed. Contexto. 2005.

CARLOTTO, M. S. A síndrome de burnout e o trabalho docente. [S.1.] Revista Psicologia em Estudo. v. 7, n. 1, p. 21-29, jan/jun 2002. Disponível em: < http://www.scielo.br/pdf/pe/v7n1/v7n1a03.pdf>. Acesso em: 18 ago. 2011.

CELANI, M. A. A. Transdisciplinarity in the teaching of English as a foreign language. In: GRIGOLETTO, M.; CARMAGNANI, A. M. G. (Orgs.). Inglês como língua estrangeira: identidade, práticas e textualidade. São Paulo: Humanitas FFLCH/USP e Enpuli. 2001. p. 29-36.

CHIZZOTTI, A. A pesquisa qualitativa em ciências humanas e sociais: evolução e desafios. Revista Portuguesa de Educação, 221-236, ano/vol 16, número 002, Universidade do Minho, Braga, Portugal. 2003. Disponível em: <http://redalyc.uaemex.mx/pdf/374/37416210.pdf >. Acesso em: 14 fev. 2012.

CORTIS, G. The Social Contexto of Teaching. London, Open Books. 1977.

DEMO, P. Saber pensar. São Paulo: Editora Cortez. 2001. p. 47-91.

DENZIN, N. K.; LINCOLN, Y. S. A disciplina e a prática da pesquisa qualitativa. Introdução. In: O planejamento da pesquisa qualitativa. Teorias e abordagens. 2. ed. Porto Alegre: Artmed, 2006, p. 15-41. Disponível em: $<$ http://imagens.extra.com.br/html/conteudo-produto/12-livros/275463/275463. pdf > Acesso em: 14 fev. 2012.

DEWEY, J. How we think. Cap. 1: What is thought. Lexington, Mass: D. C. Heath. 1910. p. 1-13. 
DIAS, F. H.; MILLER, I. K. Mudanças de footing e projeções do 'eu' de uma professora de língua inglesa: "aí dá para entender como a gente não consegue trabalhar”. In: PEREIRA, M. G. D.; BASTOS, C. R. P.; PEREIRA, T. C. (Orgs.). Discursos sócio-culturais em interação. Rio de Janeiro: Ed. Garamond. 2009.

DUFVA, H. Beliefs in dialogue: a Bakhtinian view. In: KALAJA, P.; BARCELOS, A. M. F. Beliefs About SLA: New Research Approaches. Kluwer Academic Publishers.

FABRICIO, B. F.; BASTOS, L. Narrativas e identidade de grupo: a memória como garantia do "nós" perante o "outro". In: PEREIRA, M. G. D.; BASTOS, C. R. P.; PEREIRA, T. C. (Orgs.). Discursos sócio-culturais em interação. Rio de Janeiro: Ed. Garamond. 2009.

FARRACO, C. A. Linguagem e Diálogo: As idéias linguísticas do Círculo de Bakhtin. Capítulo 2. Criar Edições. 2003.

Autor e Autoria. In: BRAIT, B. (Org). Bakhtin Conceitos-Chave. Ed. Contexto. 2005.

FREIRE, P. Educação e Mudança. São Paulo: Editora Paz e Terra. 1979.

FREIRE, P.; FAUNDEZ, A. Por uma pedagogia da pergunta. Rio de Janeiro, Editora Paz e Terra. 1985.

FREITAS, M. T. A. Bakhtin. In: Vygotsky e Bakthin: Psicologia e Educação: Um intertexto. São Paulo: Editora Ática. 2000. p. 117-153.

GAIARSA, J. A. Educação familiar e escolar para o terceiro milênio. São Paulo: Editora Ágora. 2008.

GEORGAKOPOULOU, A. The other side of the story: towards a narrative analysis of narratives-in-interaction. Abril, 2006. p. 235-257. Disponível em: <http://dis.sagepub.com/content/8/2/235.full.pdf+html> Acesso em: 17 jul. 2012.

GIEVE, S.; MILLER, I. K. Understanding the language classroom. Reino Unido: Editora Palgrave Macmillan. 2006. 
GIROUX, H. Pedagogia crítica, política cultural e o discurso da experiência (Cap.7) e Professores como Intelectuais transformadores (Cap.9). In: Os professores como intelectuais. 123-144 e 157-164. Porto Alegre, Artmed Editora. 1997.

Cruzando as fronteiras do discurso educacional: novas políticas em educação. Porto Alegre, Artmed Editora. 1999.

GUMPERZ, J. J. Convenções de contextualização. (Cap 6). In: RIBEIRO, B.; GARCEZ, P. (Orgs.). Sociolinguística Interacional. Porto Alegre, Editora Age. 1998. p. $98-119$.

HALL, S. A identidade cultural na pós-modernidade. Rio de Janeiro: DP\&A editora. 2004.

JOBIM E SOUZA, S. Bakhtin: A dimensão ideológica e dialógica da Linguagem. In: Infância e Linguagem: Bakhtin, Vygotsky e Benjamin, 97-121. Campinas, SP: Papirus Editora. 2000.

KRAMER, S. Por entre as pedras: arma e sonho na escola. São Paulo: Editora Ática. 2002.

KUMARAVADIVELU, B. Beyond methods. Yale University. 2003.

LIBERALI, F. C. Formação crítica de educadores: questões fundamentais. 01. Ed. Taubaté, SP: Cabral Editora e Livraria Universitária. 2008.

LIMA, A. H. L. “And you (teacher)...do you like learning English?": Construindo oportunidades de aprendizagem e de entendimentos sobre autonomia em um estudo de caso exploratório. Dissertação de Mestrado - Pontifícia Universidade Católica do Rio de Janeiro, Rio de Janeiro. 2009.

MARCONDES, D. Iniciação à história da filosofia. $13^{\mathrm{a}}$ ed. Rio de Janeiro: Editora Zahar, 2007. 
MILLER, I. K.; BARRETO, B. C.; MORAES BEZERRA, I. C. R., CUNHA, M. I. A.; BRAGA, W. G.; KUSCHNIR, A. N.; SETTE, M. L. Prática Exploratória: questões e desafios. In: G., GIL; VIEIRA-ABRAHÂO, M. H. (Eds) Educação dos professores de línguas: os desafios do formador. Campinas, SP: Editora Pontes. 2008. p. 145-65.

MILLER, I. K. Construindo parcerias universidade-escola: Caminhos éticos e questões crítico-reflexivas. In: GIMENEZ, T.; MONTEIRO, M. C. G. (Orgs.) Formação de professores de línguas na América Latina e transformação social. Campinas, SP: Editora Pontes. 2010. p. 109-129.

A Prática Exploratória na educação continuada de professores de línguas: inserções acadêmicas e teorizações híbridas. In: SILVA, K. A.; DANIEL, F. de G.; KANEKO-MARQUES, S. M.; SAlOMÃO, A. C. B. (Orgs.). A formação de professores de línguas: Novos olhares - Volume II. 1a ed. Campinas, SP: Editora Pontes, 2013.

MOITA LOPES, L. P. Identidades fragmentadas. Campinas, SP: Mercado das Letras. 2002.

Discursos de Identidades. Introdução. Campinas, SP: Mercado das Letras. 2003. p. 13-38.

MOREIRA, D. 4 fatos curiosos que fazem da educação na Finlândia uma exemplo. Revista Exame, 15 set. 2011. Disponível em: $<$ http://exame.abril.com.br/economia/mundo/noticias/4-fatos-curiosos-que-fazemda-educacao-na-finlandia-um-exemplo> Acesso em: 15 dez. 2011.

PEREIRA, M. G. D. A construção de discursos e identidades socioculturais: uma mudança de paradigma? In: PEREIRA, M. G. D.; BASTOS, C. R. P.; PEREIRA, T. C. (Orgs.). Discursos sócio-culturais em interação. Rio de Janeiro: Ed. Garamond. 2009.

RICHARDS, K. Qualitative inquiry in TESOL. Palgrave Macmillan. 2003. 
ROLLEMBERG, A. T. V. M. Histórias de vida de duas professoras: narrativas como instrumento de construção da identidade profissional. In: MOITA LOPES, L. P. (Org.). Discursos de Identidades. Campinas, SP: Mercado das Letras. 2003. p. $249-271$.

SALVAGGIO, M. Filosofia oriental. Disponível em: < http://pt.scribd.com/doc/20088157/Filosofia-Oriental >. Acesso em: 13 jun. 2012.

SANTIAGO, A. C. dos S. Quem sou eu, quem somos nós? Membros do grupo da Prática Exploratória buscando entender suas próprias narrativas de experiência. Dissertação de Mestrado - Pontifícia Universidade Católica do Rio de Janeiro, Rio de Janeiro. 2009.

SCHIFFRIN, D. Intonation and transcription conventions. In: Discourse markers. p. ix-x. Cambridge: Cambridge University Press, 1987.

SCHON, D. A. The Reflective Turn. Teacher College Press. 1991. Formar professores como profissionais reflexivos. In: NÓVOA, A. Os professores e sua formação. Dom Quixote, Lisboa. 1992. p.79-85.

SETTE, M. de L. A vida na sala de aula: ponto de encontro da Prática Exploratória com a Psicanálise. Tese de Doutorado - Pontifícia Universidade Católica do Rio de Janeiro, Rio de Janeiro. 2006.

SILVA, G. A. A era pós-método: o professor como um intelectual. [S.1.]: Revista Linguagens e Cidadania, edição n. 12, 12/2004. Disponível em: <http://www.ufsm.br/lec/02_04/Gisvaldo.htm>. Acesso em: 01 ago. 2011.

SILVA, J. P.; DAMÁSIO, B. F.; MELO, S. A.; AQUINO, T. A. A. Estresse e Burnout em professores. [S.1.]: Revista Fórum Identidades, ano 2, v. 3, p. 7583, jan/jun 2008. Disponível em: $<$ http://www.posgrap.ufs.br/periodicos/revista_forum_identidades/revistas/ARQ_ FORUM_IND_3/SESSAO_L_FORUM_Pg_75_83.pdf $>$. Acesso em: 18 ago. 2011. 
TANNEN, D. Appendix II. Transcription conventions. In: Talking voices. Repetition, dialogue, and imagery in conversational discourse. Cambridge, Cambridge University Press. 1989. p. 202-3

Quem está interrompendo? Questões de dominação e controle. Tradução: Débora de Carvalho Figueiredo. In: Linguagem, Gênero, Sexualidade. Editora Parábola. Coleção Linguagem. 2010.

TANNEN, D.; WALLAT, C. Enquadres interativos e esquemas de conhecimento em interação. (Cap 7). In: RIBEIRO, B; GARCEZ, P. (Org.). Sociolingüística Interacional. São Paulo, Editora Loyola. 2002. p. 183- 214.

VAN LIER, L. Some features of a theory of practice. TESOL Journal, v. 4, n.1. 1994.

VELHO, G. Observando o familiar. In: NUNES, E. de O. (Org.). A Aventura sociológica: objetividade, paixão, improviso e método na pesquisa social. Zahar editores. 1978.

WEST, C.; ZIMMERMAN, D. H. Pequenos insultos: estudo sobre interrupções em conversas entre pessoas desconhecidas de diferentes sexos. 1987. In: OSTERMANN, A. C.; FONTANA, B. (Orgs.). Linguagem, Gênero e Sexualidade. 2010. p. 49-66.

WOLCOTT, H.F. Transforming qualitative data. Capítulo 2: Description, Analysis and Interpretation in Qualitative Inquiry. Londres: Sage Publications. 1994. 


\section{7 \\ Anexos}

\section{1}

\section{Anexo I}

Entrevista, dia 21 de outubro de 2011.

Todos os nomes com asterisco ao lado foram mudados para preservar a identidade dos envolvidos.

\section{Entrevista, Trecho 1}

\begin{tabular}{|c|c|c|}
\hline $\begin{array}{l}1 \\
2\end{array}$ & Vanessa & $\begin{array}{l}\text { A primeira é o que te levou à prática exploratória, assim, como } \\
\text { você conheceu }\end{array}$ \\
\hline 3 & Waleswka & $\hat{\mathrm{E}}::$ \\
\hline 4 & Vanessa & como, $[\downarrow$ como é que foi isso $\downarrow]$ \\
\hline 5 & Waleswka & {$[\mathrm{Eu}$, eu recebi $]$ um convite para uma sessão de pôsteres } \\
\hline 6 & & de prática exploratória...pelo município. E eu sempre fiquei, né, \\
\hline 7 & & buscando uma receita, uma solução para as minhas aulas. Eu \\
\hline 8 & & tinha assim uma grande insatisfação com o que eu fazia, com o \\
\hline 9 & & que eu sentia. $>$ Não era aquilo $<$. Por mais que eu me esforçasse, \\
\hline 10 & & $>$ não era aquilo<, faltava alguma coisa. E o que eu vejo hoje \\
\hline 11 & & que faltava era essa parte humana que eu não conseguia, porque \\
\hline 12 & & a gente tá em inglês, e então, a matéria inglês, você fala inglês, \\
\hline 13 & & é uma outra língua, não tem uma coisa, ou não tinha, na época, \\
\hline 14 & & né, ou no jeito que eu trabalhava, não tinha uma aproximação. \\
\hline 15 & & Eu me lembro, assim, de ficar babando porque professores de \\
\hline 16 & & ciências, de português, eles eram muito próximos dos alunos. \\
\hline 17 & & Eles conheciam muito. E eu, queria, mas não... >tinha uma \\
\hline 18 & & barreira, eu tinha que falar inglês, eles não falavam português, \\
\hline 19 & & aquela doidera<...ninguém ficava junto, era um trabalho assim, \\
\hline 20 & & sabe...o máximo era o, o...qual é a diferença, eu me lembro isso, \\
\hline 21 & & era uma >coisa dificílima $<$ Qual a dife, é, marque na na frase a \\
\hline 22 & & diferença entre o present perfect e o simple past tense, e isso \\
\hline 23 & & eram coisas assim...não podia ser aquilo, não podia, entendeu? \\
\hline 24 & & Era muita coisa e não ia. Quando eu vi... essa sessão de \\
\hline 25 & & pôsteres...na Grande Escola de Inglês* da Tijuca, eu vi...os \\
\hline 26 & & alunos, a fala dos alunos, exercícios que nós fazíamos de simple \\
\hline 27 & & present tense, e aquilo tinha uma outra história, tinha um \\
\hline 28 & & envolvimento em inglês. E aí eu achei muito legal, comecei, foi \\
\hline 29 & & oferecido um curso, pelo..não sei, o grupo de...não sei mais \\
\hline 30 & & como se chama, seria uma APLIERJ mais ou menos hoje, de \\
\hline
\end{tabular}




\begin{tabular}{|l|l|l|}
\hline 31 & & professores de inglês, e, a, eram reuniões, se não me engano \\
32 & & quinzenais e du durante o ano 98 eu fui a essas reuniões. E aí \\
33 & & era um trabalho assim, muitas vezes eu não entendia onde é que \\
35 & & aquilo ia dar, tinha assim muito a cara de Bebel e Inés, né, do \\
36 & & jogar que eu até gosto muito, essa, essa história, até faço um \\
37 & & pouco com os meus alunos, deixar assim no ar, mas eu acho \\
38 & & isso muito interessante, né...toma...e não cobra. Toma, ó, pra \\
39 & & próxima aula isso, nem sempre a gente discutia aqueles textos, \\
40 & & então no início eu era muito perdida. Mas me encantava o modo \\
41 & & que eles...me ouviam. E, eu fui também ouvindo o meu aluno, \\
42 & & então eu era ouvida e eu aprendi a ouvir. Então foi mais ou \\
44 & & menos por aí. Nada era impossível, eu não era cobrada. Eu \\
45 & & trazia, né, nas nas reuniões a gente >falava, discutia e tal<, e aí \\
46 & eu dava...falava assim, olha, >na minha sala aconteceu<, e \\
47 & & aquilo >era discutido, era debatido<. Existia uma \\
48 & & Timportância no que eu falava. Eu tava sendo ouvida e nunca \\
49 & Vanessa & tinha sido ouvida, né, eu era ouvida, assim, pra dizer, [o aluno \\
\hline
\end{tabular}

Entrevista, Trecho 2

\begin{tabular}{|c|c|c|}
\hline 50 & Waleswka & Por que que esse aluno? O que que ele fez? Mas não prá saber \\
\hline 51 & Vanessa & {$[\downarrow$ É mesmo? Você...? ah, entendi.] } \\
\hline 52 & Waleswka & [o que estava acontecendo] na vida da sala de aula. Então não \\
\hline 53 & & tinha assim um certo e um errado. Tinha coisas que iam \\
\hline 54 & & acontecendo que a gente queria trabalhar, a gente queria \\
\hline 55 & & entender, né? Claro que isso foi construído, né, também tem \\
\hline 56 & & toda essa história super interessante de todos nós construírmos \\
\hline 57 & & a prática exploratória. Então ela pode ir pra cá, ou pra lá, \\
\hline 58 & & ela...se ${ }^{\circ}$ encaixa $^{\circ}$ no $>$ meu modo de viver, no meu modo de \\
\hline 59 & & ensinar, que tá junto do meu modo de viver, no seu, na na \\
\hline 60 & & filosofia< então vai levando, assim, né, vai tecendo essas \\
\hline 61 & & coisas e eu acho muito interessante. Mas foi exatamente isso, \\
\hline 62 & & um convite, como tantos que eu recebi. Como tanta tantos \\
\hline 63 & & seminários e eventos que eu fui. Né, eu e Solange, por \\
\hline 64 & & exemplo, >que você não conheceu porque ela agora é avó \\
\hline 65 & & duas vezes então esse ano ela tá complicada $<$, mas eu e \\
\hline 66 & & Solange nos conhecemos de conferência, de eventos, ela tava \\
\hline 67 & & lá... oi ! A gente nem sabia, mas, é curso de a Grande Escola \\
\hline 68 & & de Inglês oferece um curso para os professores do município. \\
\hline 69 & & Nós tavamos lá, e a gente chegava e tavam ensinando do, \\
\hline 70 & & does, did...pera lá, né, meu senhor? \\
\hline 71 & Vanessa & risos \\
\hline
\end{tabular}




\section{Entrevista, Trecho 3}

\begin{tabular}{|l|l|l|}
\hline 72 & Waleswka & Risos. É interessante porque isso, né? Esse imaginário, $\uparrow$ quem \\
73 & & é o professor do município, ele sabe, ele não sabe, ele não \\
74 & & fala... \\
\hline 75 & Vanessa & é \\
\hline 76 & Waleswka & Ele fala, né, todas essas coisas iam passeando naquela grande \\
77 & & teia que ia se tecendo através disso, através de conhe..., quero \\
78 & & conhecer, quero ver...onde vai dar? Mas não vai dar. E, e, \\
79 & & como é que é, e o aluno falou, e o que que é, e o que...e a \\
80 & & gente discutia muito nessas reuniões, e o que que, o que que \\
81 & & será que quer dizer, e o que que...tinha, assim, por ser \\
82 & & quinzenal, os trabalhos iam sendo feitos e a gente ia...e a \\
83 & & gente ia discutindo sobre eles, >então foi basicamente isso<, \\
84 & um convite. \\
\hline
\end{tabular}

Entrevista, Trecho 4

\begin{tabular}{|c|c|c|}
\hline $\begin{array}{l}85 \\
86\end{array}$ & Vanessa & $\begin{array}{l}\text { E, o que, o que que você define, o que que você entende por } \\
\text { prática exploratória? É fácil você definir, como é que... }\end{array}$ \\
\hline $\begin{array}{l}87 \\
88 \\
89 \\
90 \\
91 \\
92 \\
93 \\
94 \\
95 \\
96\end{array}$ & Waleswka & $\begin{array}{l}\text { TNão, a prática exploratória é um modo de...viver, uma } \\
\text { filosofia, 'que vai muito }{ }^{\circ} \text { pelo coração, pelo entendimento, } \\
\text { pelo social, pelo humano. É sempre priorizar o outro, numa } \\
\text { época de competição, de...resultados... Então talvez seja assim } \\
\text { uma coisa, e é mesmo uma coisa muito contestada, né, } \\
\text { porque...eu não me preocupo com resultado...claro que eu } \\
\text { quero que os meus alunos...sejam bem sucedidos, mas eu vejo } \\
\text { também que eles tem uma vida pela frente então não é } \\
\text { exatamente no ano de } \underline{2011} \text {, no mês de outubro, que eu tenho } \\
\text { que ficar preocupada com o índice o INDEB, sei lá, }\end{array}$ \\
\hline 97 & Vanessa & [Até porque] \\
\hline 98 & Waleswka & [ADEB...] \\
\hline $\begin{array}{l}99 \\
100 \\
101 \\
102\end{array}$ & Vanessa & $\begin{array}{l}\text { Esse livro, >até que eu tô lendo, fala<, se você fizer qualquer } \\
\text { exame...ah, os alunos aprenderam, alunos nota } 10 \text {. Pega eles } \\
\text { no quinto, sexto ano, põe eles...faça uma prova, com os } \\
\text { conteúdos anteriores. Não } \uparrow \text { vão saber. }\end{array}$ \\
\hline $\begin{array}{l}103 \\
104\end{array}$ & Waleswka & $\begin{array}{l}\text { Não vão saber, porque não, [esse talvez não sejam } \\
\text { relevantes]... }\end{array}$ \\
\hline $\begin{array}{l}105 \\
106\end{array}$ & Vanessa & $\begin{array}{l}\text { [Alunos nota 10. E eu falo por } \\
\underline{\text { mim mesma], >eu sempre fui uma [ótima]< }}\end{array}$ \\
\hline 107 & Waleswka & {$[\hat{\mathrm{E}}]$} \\
\hline $\begin{array}{l}108 \\
109\end{array}$ & Vanessa & $\begin{array}{l}>\text { Aluna e não sabia<, eu, no vestibular eu passei porque no } \\
\text { vestibular eu estudei os pontos mais importantes }\end{array}$ \\
\hline 110 & Waleswka & lógico, como todo ser [humano inteligente] \\
\hline 111 & Vanessa & [e hoje em dia], eu, não sei \\
\hline 112 & Waleswka & Claro, risos \\
\hline 113 & Vanessa & Eu não sei! \\
\hline 114 & Waleswka & Não dá, /.../ \\
\hline
\end{tabular}




\begin{tabular}{|c|c|c|}
\hline 115 & Vanessa & /.../Ah, mas você foi uma aluna...>não fui $!<$ \\
\hline 116 & Waleswka & $\overline{\mathrm{E}}$ \\
\hline 117 & Vanessa & E eu sempre tirei, >fui aluna de $10<$. E aí? \\
\hline 118 & Waleswka & Sim, por[que] \\
\hline 119 & Vanessa & {$[\underline{\mathrm{Né}}$ ?] } \\
\hline $\begin{array}{l}120 \\
121 \\
122 \\
123\end{array}$ & Waleswka & $\begin{array}{l}\text { Você aprendeu como ser aprendente que era, e é, né, você } \\
\text { aprendeu o que que era preciso prá tirar o } 10 \text {, e foi atrás do } 10 \text {, } \\
\text { mas será que educação é só chegar ao [ } 10 \text { ? O que que é o } 10 \text {, } \\
\text { né?] }\end{array}$ \\
\hline
\end{tabular}

\section{Entrevista, Trecho 5}

\begin{tabular}{|c|c|c|}
\hline $\begin{array}{l}124 \\
125\end{array}$ & Vanessa & $\begin{array}{l}\text { [exatamente, será que } \\
\text { isso] é relevante prá nossa vi[da, eu acho?] }\end{array}$ \\
\hline 126 & Waleswka & {$\left[{ }^{\circ}\right.$ Exatamente $\left.^{\circ}\right]$} \\
\hline 127 & Vanessa & Será que isso vai... \\
\hline 128 & Waleswka & É, será que é, será que não é, né, acho que outras coisas são \\
\hline 129 & & interessantes também, num co..., nesse centro de estudos, né, \\
\hline 130 & & eu fico às vezes pensando gente, será que só eu que tô \\
\hline 131 & & pensando, mas depois eu vou assim, e vou vendo que outras \\
\hline 132 & & pessoas também falam, pensam, mas não falam. É que eu...né, \\
\hline 133 & & a prática exploratória me deu essa, essa...destrava, né? A \\
\hline 134 & & educação travou, a prática exp exploratória destravou, essa \\
\hline 135 & & não censura, dizer o que eu penso, não importa, >cê achou que \\
\hline 136 & & 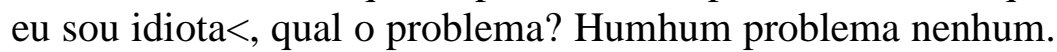 \\
\hline 137 & & Mas, no centro de estudos estavam...estávamos discutindo \\
\hline 138 & & sobre chegada, pontualidade. Dos professores, porque houve \\
\hline 139 & & uma denúncia, enfim >essas coisas de escola<. Ouvidoria, aí \\
\hline 140 & & foram lá, chegaram, e >claro os professores $<$ não estavam na \\
\hline 141 & & sala. Havia, até professores...que estavam na escola mas não \\
\hline 142 & & na sala de aula. Os professores se sentem ofendidos $\mathrm{e}$ \\
\hline 143 & & invadidos, porque ${ }^{\circ}$ como chegou alguém para fiscalizar o meu \\
\hline 144 & & horário ${ }^{\circ}$ ? Se não tem aluno? Aí, eu, assim, gente, será que eu \\
\hline 145 & & ${ }^{\circ}$ estou maluca ${ }^{\circ}$ ? Mas eu acho que se você tem um horário, se \\
\hline 146 & & 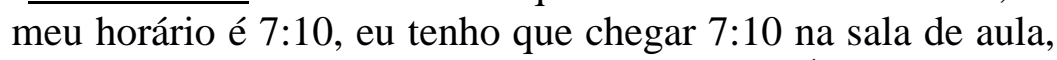 \\
\hline 147 & & eu tenho que chegar 7 horas prá tá na...> se $\uparrow$ tem aluno ou \\
\hline 148 & & não $<$, eu não $\uparrow$ quero saber, eu posso ter $>$ cinco, quatro, três $<$, \\
\hline 149 & & eu só vou de manhã um dia, eu não posso perder esse tempo. \\
\hline 150 & & Então, prá mim...houve...houve uma denúncia, a ouvidoria \\
\hline 151 & & chegou...e constatou, então eu não, a escola não pode ficar \\
\hline 152 & & melindrada ou se sentir ofendida, porque está errada. Né? Eh, \\
\hline 153 & & pode ser que a gente mude o horário mas isso tem que ser um \\
\hline 154 & & consenso na comunidade, né? Não dá pra chegar. Então, o que \\
\hline 155 & & que foi sugerido? Foi sugerido...os alunos não chegam. Eu, até \\
\hline 156 & & falei com meu companheiro, o Ivan* lá na hora: Olha, eles \\
\hline 157 & & não chegam é efeito tostines, se eles chegarem não tem \\
\hline 158 & & professor, professor não tem aluno...então isso vai se \\
\hline 159 & & prolongando. Mas eu [chego sexta-feira] \\
\hline 160 & Vanessa & [Efeito tostines é ótimo] \\
\hline
\end{tabular}




\begin{tabular}{|l|l|l|}
\hline 161 & Waleswka & Eu chego sexta-feira, no horário (smack) \\
\hline 162 & Mulher 1 & Oi, [tudo bom?] \\
\hline 163 & Waleswka & [Tudo bom] quer[ida?] \\
\hline 164 & Mulher 1 & \multicolumn{1}{c|}{ [Oi] } \\
\hline 165 & Vanessa & Oi \\
\hline 166 & Waleswka & Nós estamos numa... \\
\hline 167 & Mulher 1 & Onde é, hein? \\
\hline 168 & Waleswka & $\begin{array}{l}\text { 1008, aí nesse meiozinho, tá? >A gente já vai<. Aí, eh...a } \\
\text { gente, eh...Enfim, >já não me lembro mais<, mas, eh... }\end{array}$ \\
\hline
\end{tabular}

Entrevista, Trecho 6

\begin{tabular}{|c|c|c|}
\hline 170 & Vanessa & Que houve uma ${ }^{\circ}$ denúncia $^{\circ} \ldots$ \\
\hline 171 & Waleswka & Houv...[sim...] \\
\hline 172 & Vanessa & {$[$ Cê acha] que... } \\
\hline 173 & Waleswka & Eu acho que não, não tinha a ver... \\
\hline 174 & Vanessa & $1 \ldots /$ \\
\hline 175 & Waleswka & [Se] estamos errados, nós não temos que ficar indignados, nós \\
\hline 176 & & temos que ver, ah mas nós não podemos, é muito longe, os \\
\hline 177 & & alunos não chegam, pro professor também tem obras...então \\
\hline 178 & & 个isso não é um assunto pra se tratar?, ou seja, o aluno tem \\
\hline 179 & & um...Riocard. O Riocard permite que ele faça cinco viagens. \\
\hline 180 & & Então, a solução da Direção é: se ele não...ele vem, né? Eu \\
\hline 181 & & venho. Saio do de Ipanema, posto seis, enfim...eh...eu posso \\
\hline 182 & & pegar dois ônibus. Eu, eu aluno, né? Eu pego dois ônibus prá \\
\hline 183 & & $>$ chegar no horário $<$. Gente, mas isso não está certo, porque \\
\hline 184 & & aquilo custa. Quem paga é o contribuinte, isso sai do dinheiro \\
\hline 185 & & dos impostos. Aquela $\uparrow$ passagem não é gratuita. Então $\uparrow$ olha \\
\hline 186 & & que oportunidade a escola tem...um assunto que >é \\
\hline 187 & & importante, é vital< prá escola: como chegar na hora certa. \\
\hline 188 & & Porque chegar na hora certa $\uparrow$ ? Porque não usar cinco $\uparrow$ ? Que é \\
\hline 189 & & a questão ética. E...foi resolvido, e, o eh...eh, enfim, se...o que \\
\hline 190 & & você, por favor, só tira assim os nomes que por acaso eu vou \\
\hline 191 & & falando, né? Isso eu sei [que] cê faz, né? \\
\hline
\end{tabular}

Entrevista, trecho 7

\begin{tabular}{|c|c|c|}
\hline 192 & Vanessa & {$[/ \ldots /]$} \\
\hline $\begin{array}{l}193 \\
194\end{array}$ & Waleswka & $\begin{array}{l}\text { Porque...infelizmente eu acabo falando, né? Eu digo pros } \\
\text { meninos, vocês não podem falar [quem é o professor] }\end{array}$ \\
\hline 195 & Vanessa & {$[($ risos $)]$} \\
\hline $\begin{array}{l}196 \\
197 \\
198 \\
199\end{array}$ & Waleswka & $\begin{array}{l}\text { Mas a gente acaba...né? É interessante que a gente vê isso, } \\
\text { como sai naturalmente...mas...o coordenador falou: Mas nós } \\
\text { não temos que resolver esse problema. Se é problema de } \\
\text { transporte eles têm cinco...passagens, eles usem as cinco }\end{array}$ \\
\hline
\end{tabular}

\footnotetext{
${ }^{52}$ A situação na qual a professora orienta os alunos a não falar o nome do professor é quando eles apresentam pôsteres e algum professor citado não está presente.
} 


\begin{tabular}{|c|c|}
\hline $\begin{array}{l}200 \\
201 \\
202 \\
203 \\
204 \\
205 \\
206 \\
207 \\
208 \\
209 \\
210 \\
211 \\
212 \\
213 \\
214 \\
215 \\
216 \\
217 \\
218 \\
219 \\
220 \\
221 \\
222 \\
223 \\
224 \\
225 \\
226 \\
227 \\
228 \\
229 \\
230 \\
231 \\
232 \\
233 \\
234 \\
235 \\
236 \\
237 \\
238 \\
239 \\
240 \\
241 \\
242 \\
243 \\
244 \\
245\end{array}$ & 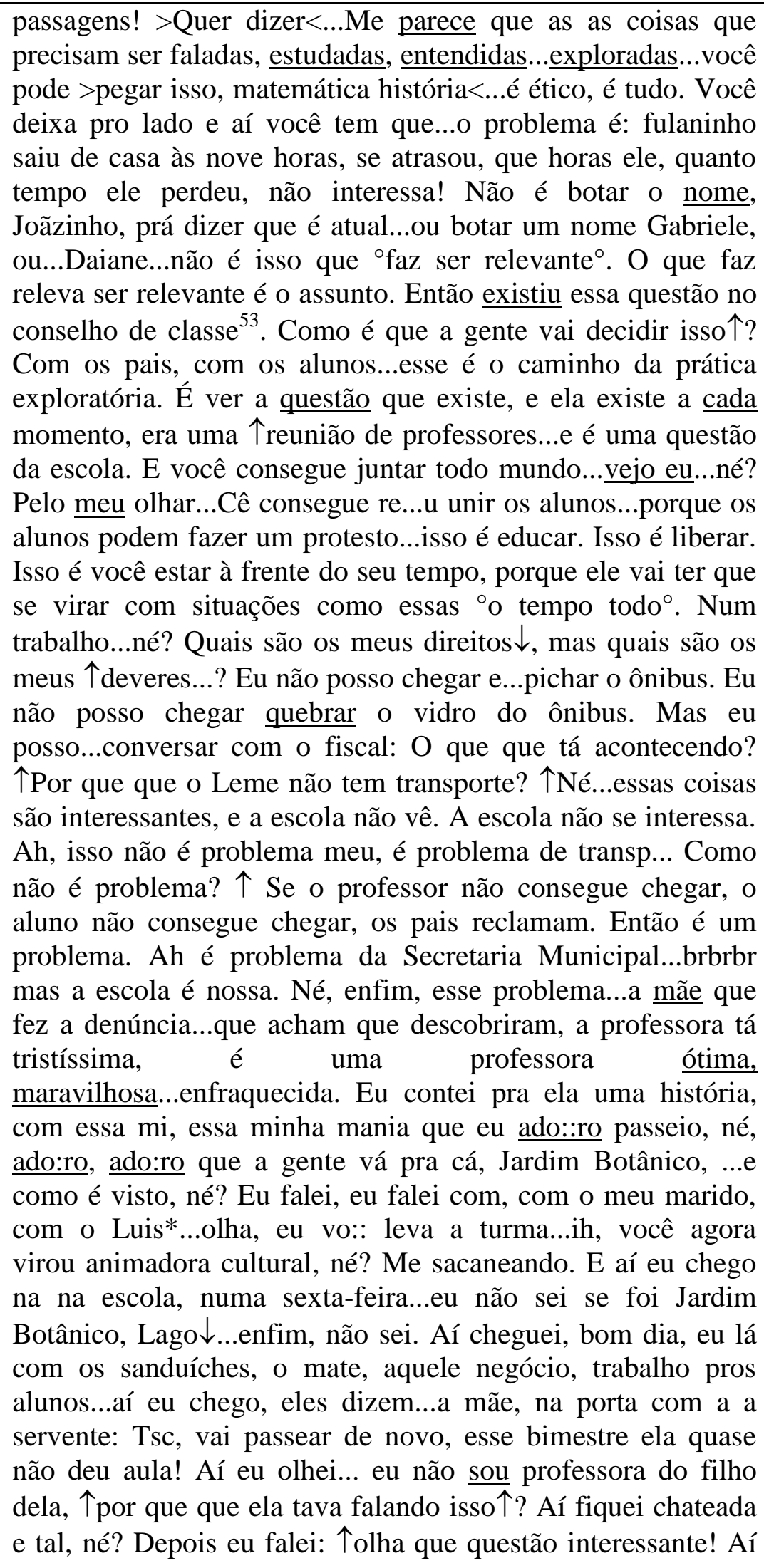 \\
\hline
\end{tabular}

${ }^{53} \mathrm{Na}$ conversa seguinte, Walewska já havia lido a transcrição e esclareceu que aqui ela quis dizer "centro de estudos", e não "conselho de classe". 


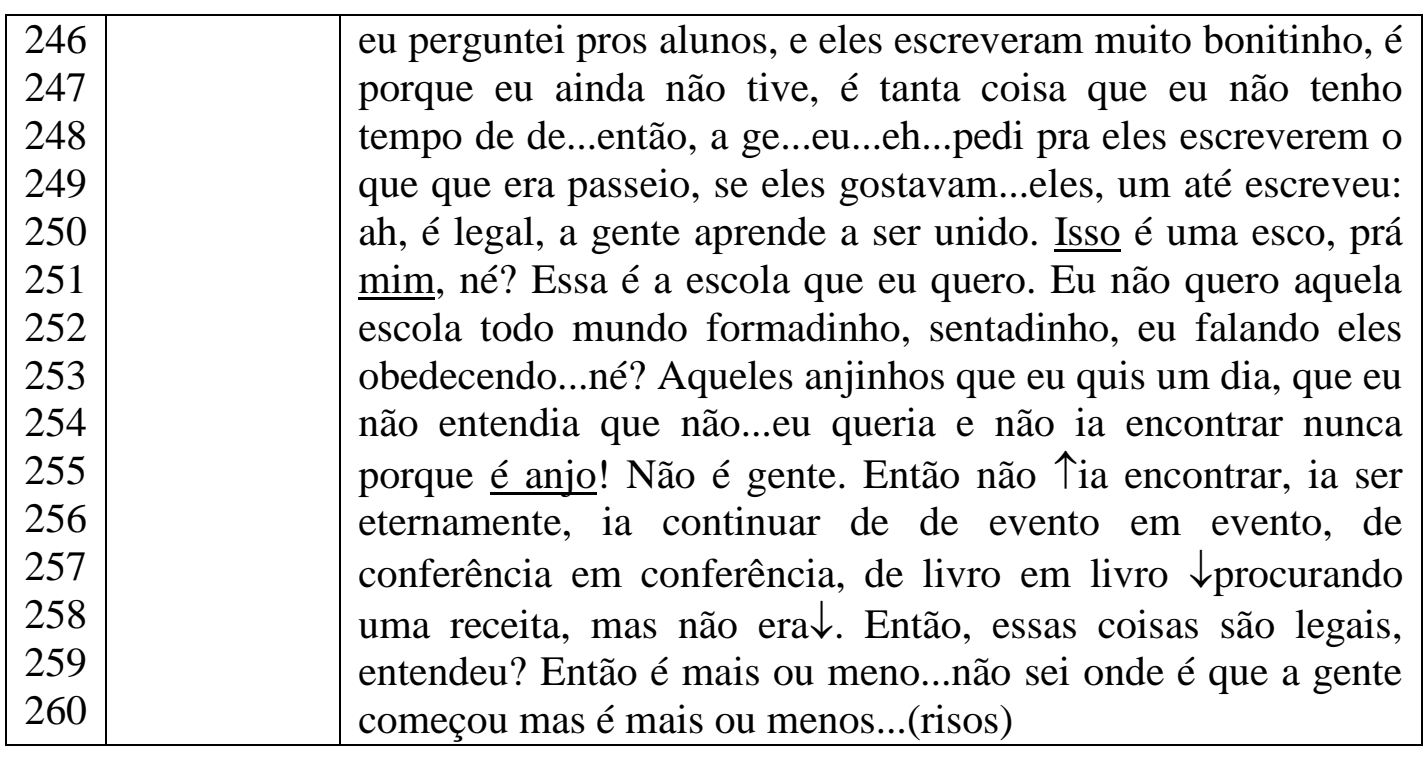

Entrevista, trecho 8

\begin{tabular}{|c|c|c|}
\hline 261 & Vanessa & $>$ Você acha que, tipo assim $<$ \\
\hline 262 & Walewska & Boa sorte na transcrição \\
\hline 263 & Vanessa & Olha só...não acabou ainda. \\
\hline 264 & Walewska & Risos...mas é hilário. \\
\hline 265 & Vanessa & Não, não é não, eu acho legal. \\
\hline 266 & Walewska & Ai... \\
\hline $\begin{array}{l}267 \\
268 \\
269 \\
270 \\
271 \\
272\end{array}$ & Vanessa & $\begin{array}{l}\text { Eu acho...é porque eu acho que é mais ou menos...é mais ou } \\
\text { menos o que eu penso também, é mais ou menos...o que eu...o } \\
\text { que eu...também...eu eu chego à conclusão } \\
\text { porque...na...quando eu comecei na prática exploratória, eu } \\
\text { não entendia nada, também achava aquilo uma coisa de } \\
\text { louco... }\end{array}$ \\
\hline 273 & Walewska & Risos...é muito diferente, [né? É muito diferente.] \\
\hline $\begin{array}{l}274 \\
275\end{array}$ & Vanessa & $\begin{array}{l}\text { [Eu não entendia, e hoje em dia] } \\
\text { eu vejo...> de uma maneira muito clara< }\end{array}$ \\
\hline 276 & Walewska & 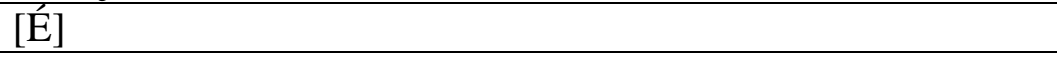 \\
\hline $\begin{array}{l}277 \\
278\end{array}$ & Vanessa & $\begin{array}{l}\text { [mas] eu também entendo que as pessoas não conseguem } \\
\text { enxergar porque o mundo não é feito > pra isso }<\text {. }\end{array}$ \\
\hline 279 & Walewska & {$[\mathrm{E}]$.} \\
\hline $\begin{array}{l}280 \\
281 \\
282 \\
283\end{array}$ & Vanessa & $\begin{array}{l}\text { [O mundo], ele ele ele tolhe primeiro sua capacidade de } \\
\text { raciocínio, ele embota...muitas vezes...e você, é incapaz de } \\
\text { > você refletir criticamente<, então você chega, você faz, você } \\
\text { reproduz um padrão, que lhe foi ensinado, }\end{array}$ \\
\hline 284 & Walewska & Que você sabe [que é falho] \\
\hline $\begin{array}{l}285 \\
286 \\
287\end{array}$ & Vanessa & $\begin{array}{l}\text { [e prá], }{ }^{\circ} \text { aquilo é certo prá } \\
\text { você }{ }^{\circ} \text {, eh você jamais parou prá pensar...se é ou se não é, } \\
\text { refletir de verdade. }\end{array}$ \\
\hline 288 & Walewska & [É.] \\
\hline
\end{tabular}




\section{Entrevista, trecho 9}

\begin{tabular}{|c|c|c|}
\hline 289 & Vanessa & [Eu] acho que isso...é uma oportunidade. [Eh, é super legal.] \\
\hline 290 & \multirow[t]{46}{*}{ Walewska } & [É, tudo é] tem assim \\
\hline 291 & & umas partes, eh, eu...até às vezes fico assim achando que eu \\
\hline 292 & & vou de de frase...de de...eh...citação em citação do Allwright. \\
\hline 293 & & Logo no início eu gostava muito, porque era significativo pra \\
\hline 294 & & $\underline{\text { mim}}$, a história da eficiência. Não busque eficiência, busque \\
\hline 295 & & entender...Ou seja...o $\uparrow$ resultado, ele vai vir $\downarrow$. Mas se você \\
\hline 296 & & entender...que é difícil, que vai demorar...que o menino \\
\hline 297 & & naquele momento não podia mesmo te prestar atenção no que \\
\hline 298 & & você tava falando porque ele saiu de casa, e...viu uma briga, \\
\hline 299 & & viu um cadáver, eu sei lá, enfim, o que que acontece com eles. \\
\hline 300 & & Ou $\uparrow$ simplesmente estar sonhando com a namorada, como os \\
\hline 301 & & meninos do nono ano com a deusa...dourada, né? Aquela \\
\hline 302 & & $\underline{\text { deusa, }}$ que eles adoram, aí eles chegam todos $\underline{\text { atrasados, }}$, ao \\
\hline 303 & & mesmo tempo, a deusa na frente, e eles atrás....mas é bonito \\
\hline 304 & & aquilo, né? É lindo, é vida. $\widehat{\uparrow E}$ aí ele não pode, realmente, \\
\hline 305 & & pegar lá o livro da página 160 e sei lá quantos, que tá \\
\hline 306 & & contáveis e incontáveis... 个quem é que agüenta isso, né? Eu \\
\hline 307 & & tento assim, bom, eu tenho que vender esse peixe, dos \\
\hline 308 & & contáveis e incontáveis, aí eu ponho lá uma tarefa. Discreta \\
\hline 309 & & ali, né?, ce vê: $\uparrow$ comparativo. Discreto, ali. Vai mais ou vai \\
\hline 310 & & menos, vai dar samba ou não, dependendo do que eu vir, \\
\hline 311 & & $>\uparrow$ porque ele vai ter a vida toda pra aprender countable e \\
\hline 312 & & uncountable<, tem que ser no dia 21 de outubro个? Não, \\
\hline 314 & & porque ontem morreu o Khadafi $\downarrow$, na outra semana foi o \\
\hline 315 & & Steve Jobs $\downarrow$...e o $\uparrow$ que que a gente não vai discutir sobre, não \\
\hline 316 & & vamos falar ${ }^{\circ}$ sobre a barbárie ${ }^{\circ}$, né, o que que é um povo que \\
\hline 317 & & foi submisso, que ff sofreu, que foi massacrado e que viu que \\
\hline 318 & & não era certo. Mas de repente, quando pega \\
\hline 319 & & justiça, procura a barbárie, então ${ }^{\circ}$ mata daquele \\
\hline 320 & & jeito $^{\circ}$, né? $\mathrm{E}>$ você não discute $<$, teve uma me uma menina, a \\
\hline 321 & & Lúcia*, que eu ado/.../ A Lúcia*, que eu adoro, que ela falou \\
\hline 322 & & assim: Não, professora, é isso mesmo. Aí quando eu comecei \\
\hline 323 & & a falar, eu falei: Respeito sua sua posição, Lúcia*. Claro, \\
\hline 324 & & você, como você, muita $\uparrow$ gente pensa assim. Fez errado $\uparrow ?$ \\
\hline 325 & & Roubou个? Corta a mão. Tem muita gente que pensa assim. \\
\hline 326 & & Mas será que é isso $\uparrow$ ? Será que é exatamente isso $\uparrow$ ? Isso vai \\
\hline 327 & & vai fazer alguma pessoa....se corrigir, vai faz...ninguém erra $\uparrow$ ? \\
\hline 328 & & A gente tem que ser tão punido? Ou a gente pode... ${ }^{\circ}$ passar \\
\hline 329 & & por um julgamento ${ }^{\circ},{ }^{\circ}$ a gente pode ${ }^{\circ}$ ser julgado e condenado? \\
\hline 330 & & Ele errou, ele matou, ele fez, mas a gente vai fazer...a mesma \\
\hline 331 & & coisa, então se a gente achou errado a gente vai fazer o errado. \\
\hline 332 & & Essa coisa, entendeu, é que eu acho que a prática exploratória \\
\hline 333 & & te libera para ousar trazer na sala de aula. Porque do que eu vi \\
\hline 334 & & lá, na na sala dos professores, o professor de história, o \\
\hline 335 & & professor de teatro, de matemática, todo mundo tem um \\
\hline 336 & & planejamento pra seguir. Mas e a vida?...Né? E a vida? Você \\
\hline
\end{tabular}




\begin{tabular}{|c|c|c|}
\hline $\begin{array}{l}337 \\
338 \\
339 \\
340 \\
341 \\
342 \\
343 \\
344 \\
345 \\
346 \\
347 \\
348 \\
349 \\
350 \\
351 \\
352 \\
353 \\
354\end{array}$ & & $\begin{array}{l}\text { não } \uparrow \text { vai discutir um Steve Jobs? Quando ele morreu eu } \\
\text { peguei aquele discurso...da Universidade de Stanford, e } \\
\text { peguei com os meus alunos todos, desde a sexta série...que } \\
\text { realmente, eles se batiam, o negócio }{ }^{54} \text { não funcionava, era } \\
\text { uma loucura...mas o a } 802 \text {, a } 902 \text {, eles olharam aquilo porque } \\
\text { aquilo tinha a ver com eles. Falava de suce:sso, de fazer } \\
\text { alguma coisa na gara:gem, né? De ser um ne:rd...De >ganhar } \\
\text { dinheiro, de perder dinheiro<. De ta doente, de num sa, } \\
\text { de...ser adota:do...aquilo era a vida...que eles, é uma novela, } \\
\text { talvez, né? Você vê que eu, eu adoro coisa de jornal, eu acho } \\
\text { jornal uma coisa super interessante porque fala da realida, } \\
\text { claro, a gente, né? /.../to, to vendo as tendê:ncias, as } \\
\text { comprometime:ntos, a ideologia, mas a história do jornal é } \\
\text { legal. Porque o jornal, ele tem essa agilidade, online, } \\
\text { principalmente, de falar de } 150 \text { mil assuntos. Eu queria que a } \\
\text { minha aula pudesse ser assim, entendeu, um jornal } \uparrow ? \text { ?m dia } \\
\text { eu acho que vai...risos, por isso que eu não me aposento, } \\
\text { porque eu tenho [esperança] }\end{array}$ \\
\hline $\begin{array}{l}355 \\
356\end{array}$ & Vanessa & $\begin{array}{l}\text { [Tem esperança], a esperança morre depois } \\
\text { da mulher, é o que eu sempre falo. [(Risos)] }\end{array}$ \\
\hline 357 & Walewska & {$[($ Risos $)] \mathrm{Ai}[$ meu Deus do céu.] } \\
\hline
\end{tabular}

Entrevista, trecho 10

\begin{tabular}{|c|c|c|}
\hline $\begin{array}{l}358 \\
359 \\
360 \\
361 \\
362\end{array}$ & Vanessa & $\begin{array}{l}\text { [Mas eu fico pensando] } \\
\text { também, eu fico pensando nisso, tipo assim, nossa...se bem } \\
\text { que....aí eu...eu não tenho na ver...Fico pensando, nossa, teria } \\
\text { que ter muito tempo pra gente conseguir ver tudo, mas ao } \\
\text { mesmo tempo... }\end{array}$ \\
\hline 363 & Walewska & Um pouquinho que seja \\
\hline $\begin{array}{l}364 \\
365 \\
366 \\
\end{array}$ & Vanessa & $\begin{array}{l}\text { Precisa ver tudo? Será que a gente pre, será que precisa } \\
\text { mesmo } \uparrow \text { ? } \\
\quad \text { [Será que isso...] }\end{array}$ \\
\hline $\begin{array}{l}367 \\
368\end{array}$ & Walewska & $\begin{array}{l}\text { A gen[te não ace], não abre todas as notícias, você len, ah, } \\
\text { isso aqui me interessa, [eu vou viajar] }\end{array}$ \\
\hline 369 & Vanessa & [será que] \\
\hline $\begin{array}{l}370 \\
371 \\
372 \\
373 \\
374 \\
375 \\
376 \\
377 \\
378 \\
379\end{array}$ & Walewska & $\begin{array}{l}\text { Eu vou viajar, quero ver, eu não vou viajar, então não vou } \\
\text { ver } \downarrow \text {...né? e isso eu acho, até me:smo, né, nessa esco::la, } \\
\text { assim, como eu acho que seria uma escola...assim, gostosa, } \\
\text { né...eh o aluno poderia escolher...como é que ele vai } \\
>\text { trabalhar, agora<, operacionalizar isso, nem sempre é fácil } \\
\text { porque envolve, né, trocentas coisas...mas eu acho que você } \\
\text { ousar na medida do que faz é você também alimentar o prazer } \\
\text { de trabalhar, o prazer de viver, né? Porque uma das coisas que } \\
\text { a gente lo::go descobriu com os alunos...é que } \uparrow \text { a vida deles é: }\end{array}$ \\
\hline
\end{tabular}

${ }^{54} \mathrm{O}$ "negócio" que não funcionava era o data show. 


\begin{tabular}{|c|c|}
\hline $\begin{array}{l}380 \\
381 \\
382 \\
383 \\
384 \\
385 \\
386 \\
387 \\
388 \\
389\end{array}$ & $\begin{array}{l}\text { aquela. Eles passam to:dos, e, não sei quanto tempo, todos os } \\
\text { dias, de segunda a sexta-feira então eles tão vivendo ali, o } \\
\text { professor também. Eh, às vezes tem gente que fala: Ah, eh, } \\
\text { nós vamos sair, e tá proibido falar de aluno. } \uparrow \underline{\text { Como ce vai }} \\
\text { conseguir, né? É muito...cê não tem que falar só de aluno, mas } \\
\text { ele faz parte da tua vida, você tá num grupo que vive, vive } \\
\text { vivencia a mesma coisa, então não dá pra você proibir esse } \\
\text { assunto, ou então gente que fala: ai, eu tenho vida fora da } \\
\text { escola...e dentro também, deveria ter, né? Eu tenho uma vida } \\
\text { fora da escola, e dentro da escola você faz o que? (Risos) } \\
\text { Vegeta? }\end{array}$ \\
\hline
\end{tabular}

\section{Entrevista, trecho 11}

\begin{tabular}{|c|c|c|}
\hline 390 & Vanessa & Passa o [tempo.] \\
\hline $\begin{array}{l}391 \\
392 \\
393 \\
394 \\
395 \\
396 \\
397 \\
398 \\
399 \\
400\end{array}$ & Walewska & $\begin{array}{l}\text { [Toma algum] sei lá, calmante, fuma, eu não sei o } \\
\text { que que é, né? Mas essa } \uparrow \text { idéia...do ter prazer no que você } \\
{ }^{\circ} \text { faz que se realimenta }{ }^{\circ} \text { né? O legal também da prática } \\
\text { exploratória é essa história da }{ }^{\circ} \text { realimentação }{ }^{\circ} \text { É você, como } \\
\text { você não tem compromisso com o sucesso, com a realização, } \\
\text { como você pode ousar, porque cê quer entender } \uparrow \text {, você não } \\
\text { quer...chegar ali. Eu não quero que todos os meus alunos } \\
\text { passem no INDE:B da vida com um...sei lá, nem sei bem o } \\
\text { que que é isso, mas enfim...é um índice que a gente tem, que } \\
\text { se a gente conseguir, a gente ganha um [salário a mais.] }\end{array}$ \\
\hline $\begin{array}{l}401 \\
402\end{array}$ & Vanessa & Educação Básica, [né?] $\quad$ [Índice de De]senvolvimento da \\
\hline $\begin{array}{l}403 \\
404 \\
405 \\
406 \\
407 \\
408 \\
409 \\
410 \\
411 \\
412 \\
413 \\
414 \\
415 \\
416 \\
417 \\
418 \\
419 \\
420 \\
422 \\
423 \\
424\end{array}$ & Walewska & $\begin{array}{l}\text { [É], se a gente conseguir, a gente num } \\
\text { consegue, a minha escola nunca consegue...(risos) mas, se a } \\
\text { gente conseguir, a gente...ganha um salário a mais. Um salário } \\
\text { a mais você vai fazer } \uparrow \text { dívidas a mais, né, porque, eu } \\
\text { também...da minha experiência é quanto mais você tem, mais } \\
\text { você vai gastar. Enfim } \uparrow \text {, vai se endividar mais, mas, pode ser } \\
\text { né } \uparrow \text {, eu quero ganhar, mas cê pode ganhar também, a longo } \\
\text { prazo, um prazo um pouquinho maior se o seu aluno } \uparrow \text { for } \\
\text { crítico, tiver prazer em estudar...né? O } \uparrow \text { que que você vai } \\
\text { fazer prá um adolescente, você viu... }{ }^{\circ} \text { para que eles estudem }{ }^{\circ} \text { ? } \\
\text { Não tem jeito, você não pode abrir a cabeça e falar: estudem. } \\
\text { }{ }^{\circ} \text { Prá ele o significado do estudo tá assim muito }{ }^{\circ} . . \text { ligado a a ao } \\
\text { não prazer, ao obrigação, que não leva a nada }{ }^{\circ} \text {...né? Porque } \\
\text { alguns acham que não são nada, não vão ser nada...e outros } \\
\text { acham que não vão precisar daquilo. São os mais sábios. } \\
\text { Realmente daquilo ali muito pouco eles vão precisar, mas eles } \\
\text { precisam aprender a conviver } \uparrow . . . \text { uns com os outros, com } \\
\text { pessoas que tem idéias diferentes, né, isso é muito difícil, } \\
\text { ainda pra eles, né, com essa } \uparrow \text { vontade de fazer as coisas, e } \\
\text { fazer, não ficar só na vontade, porque eles tem muitas idéias, } \\
\text { eles são muito criativos, mas o fazer é mais difícil. Por isso, }\end{array}$ \\
\hline
\end{tabular}




\begin{tabular}{|l|l|l|}
\hline 425 & & por essa correria mesmo, todo, tudo é muito corrido $\downarrow$, tudo é \\
426 & & muito corrido $\downarrow$, eu acho que a única coisa que não corre é o \\
427 & & tempo da sala de aula...que tá parado...né? Você passar ali a \\
429 & & manhã inteira fazendo ${ }^{\circ}$ exercício de matemática no quadro \\
430 & & não pode ser prazeroso prá ninguém. Normal...né? Pode ter o \\
431 & & prazer louco, mas não... $\uparrow$ oi, $\uparrow$ bonitinha! \\
\hline 432 & Mulher 2 & Olá /.../ \\
\hline
\end{tabular}

Entrevista, trecho 12

\begin{tabular}{|c|c|c|}
\hline 433 & Vanessa & É...você acha que...que...a sua vida...a sua vida. Walewska. \\
\hline 434 & Walewska & Sim. \\
\hline $\begin{array}{l}435 \\
436 \\
437\end{array}$ & Vanessa & $\begin{array}{l}\text { Até mesmo fora da escola. Dentro da escola a gente tá } \\
\text { conversando...já. Cê acha que a PE modificou a sua maneira } \\
\text { de ver a vida? }\end{array}$ \\
\hline 438 & Walewska & Ah, isso sim. \\
\hline 439 & Vanessa & Como? \\
\hline $\begin{array}{l}440 \\
441 \\
442 \\
443 \\
444\end{array}$ & Walewska & $\begin{array}{l}\text { Sempre modifica, Vanessa. Até porque você vai...fazendo o } \\
\text { que você acredita. Tem que ter alguma coisa, quer dizer,no } \\
\text { meu caso teve alguma coisa eu buscava eu encontrei. Eu } \\
\text { buscava eu encontrei e...isso...emergiu. Né? Eu tive uma } \\
\text { educação muito...eh...restritiva a gente fala, não? }\end{array}$ \\
\hline 445 & Vanessa & Rígida. \\
\hline $\begin{array}{l}446 \\
447 \\
448 \\
449 \\
450 \\
451 \\
452 \\
453 \\
454 \\
455 \\
456 \\
457 \\
458 \\
459 \\
460 \\
461 \\
462 \\
463 \\
464 \\
465 \\
466 \\
467 \\
468\end{array}$ & Walewska & 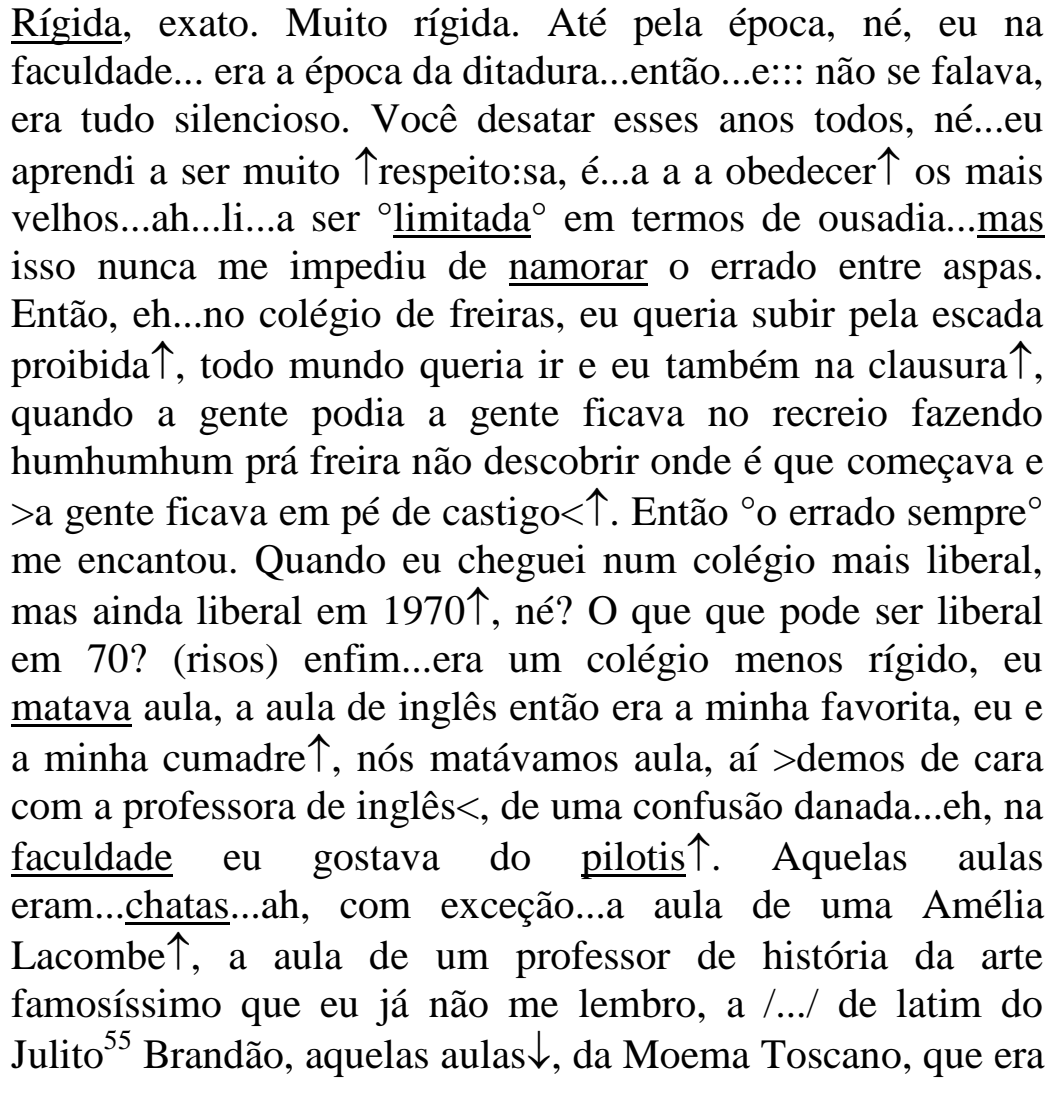 \\
\hline
\end{tabular}

${ }^{55} \mathrm{O}$ nome correto é Junito 


\begin{tabular}{|c|c|c|}
\hline $\begin{array}{l}469 \\
470 \\
471\end{array}$ & & 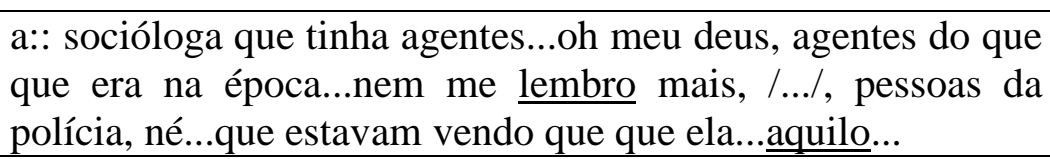 \\
\hline 472 & Vanessa & DOI-CODI? \\
\hline 473 & Walewska & Nem do DOI-CO... DOI-CODI ${ }^{56}$ eu acho que já era...a re... \\
\hline
\end{tabular}

\section{Entrevista, trecho 13}

\begin{tabular}{|c|c|c|}
\hline 474 & Vanessa & [A ditadura, né? A repressão.] \\
\hline 475 & \multirow[t]{35}{*}{ Walewska } & [É...mas então], eram os os caras, os espiões, do governo, que \\
\hline 476 & & assistiam, então você sabia, você ia pra aula da Moema \\
\hline 477 & & Toscano e tal...era o máximo, né? Essa vida me encantava, \\
\hline 478 & & não tanto os livros. Né, não tanto, eu colava nas provas \\
\hline 479 & & ${ }^{\circ}$ alucinadamente $^{\circ}$. Eu não entendia $\uparrow$, eu tinha feito Normal $\uparrow$, \\
\hline 480 & & eu não $\uparrow$ tinha fundamento de nada. Então...esse lado \\
\hline 481 & & assim...a transgressão, sempre me encantou. A Prática \\
\hline 482 & & Exploratória...de certa forma, destampou isso e me fez ver \\
\hline 483 & & que essas transgressões eram $\uparrow$ interessantes...por isso eu \\
\hline 484 & & buscava os anjos...né? Porque eu não queria a transgressão. \\
\hline 485 & & Porque eu não fui criada na transgressão. Mas eu me \\
\hline 486 & & apaixonei pela transgressão. Então eu me encantei pelos \\
\hline 487 & & fantasminhas, os diabos eram muito mais interessantes que os \\
\hline 488 & & anjos...mas isso tudo, né...em mim, era tudo misturado. E na \\
\hline 489 & & vida também $\uparrow$. Eh o ouvir o outro...que é fundamental na \\
\hline 490 & & Prática Exploratória porque você vai aprender com o outro, \\
\hline 491 & & então você tem que ouvir $\downarrow$, vocês dois vão crescer juntos, \\
\hline 492 & & então eu tenho que ouvir o que você quer dizer $\uparrow$, não importa \\
\hline $\begin{array}{l}493 \\
494\end{array}$ & & se você é aluna, né...isso foi importante, numa época...assim, \\
\hline 495 & & né...se eu for...contextualizar, se eu for deixar uma coisa, \\
\hline 496 & & eh...fechada. Eh::: uma época em que eu tive que conviver \\
\hline 497 & & tinha um quadro de uma mãe...eh...com Alzheimer, cinco \\
\hline 498 & & cuidadores, mais o pessoal de...de final de semana, folguistas, \\
\hline $\begin{array}{l}499 \\
500\end{array}$ & & né, e como é que eu consegui trabalhar aquele \\
\hline 500 & & 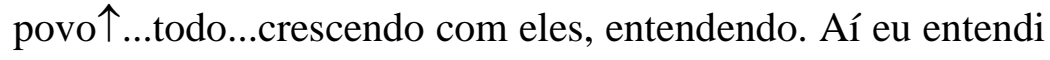 \\
\hline 502 & & que eu tinha ${ }^{\circ}$ uma empregada que tinha sete filhos ${ }^{\circ}$. Como é \\
\hline 503 & & que você tem sete filhos...trabalha...esses sete filhos, no \\
\hline 504 & & até a hora da mais velha ${ }^{\circ}$ voltar da escola....abril \\
\hline 505 & & levar pra escola ${ }^{\circ} . . . e$ aí eu fui começando a ouvir aquilo, e \\
\hline 506 & & aquilo foi importante pra mim, >não, isso não pod, essa \\
\hline $\begin{array}{l}507 \\
508\end{array}$ & & situação eu não quero<, vamos resolver isso? > Que que pod, \\
\hline 509 & & ah eu preciso<, então você vai ter esse dinheiro pra você \\
\hline 510 & & botar uma pessoa pra tomar conta, não pode, não podem ficar \\
\hline 511 & & trancados. Em...e eu tenho certeza, Vanessa, que...se isso \\
\hline 512 & & \\
\hline
\end{tabular}

${ }^{56}$ O nome correto é DOPS (Departamento de Ordem Política e Social) 


\begin{tabular}{|c|c|c|}
\hline $\begin{array}{l}513 \\
514 \\
515 \\
516 \\
517 \\
518 \\
519 \\
520 \\
521 \\
522\end{array}$ & & $\begin{array}{l}\text { nem querendo saber }<\ldots \text { era um trabalho, era uma coisa } \\
\text { profissional...ent }{ }^{\circ} \text { essas moças todas }{ }^{\circ} \text { me ensinaram muito. } \mathrm{O} \\
\text { que que é a mãe dos meus alunos. Porque a mãe dos meus } \\
\text { alunos, não é } \uparrow \text { a minha, não é } \uparrow a \text { minha mãe, a mãe que eu } \\
\text { tive...provavelmente a mãe que você teve. É essa } \uparrow \underline{\text { mãe que }} \\
\text { tem sete filhos. Como é que é isso } \uparrow \text { ? Como é que } \uparrow \text { o mais } \\
\text { velho toma conta do menor? Ah, isso na minha sala } \\
\text { também } \downarrow \text {. Então entender as pessoas e aprender >quantas } \\
\text { coisas elas me ensinaram, até coisas práticas, eu não sabia } \\
\text { fritar< uma um bife... }\end{array}$ \\
\hline 523 & Vanessa & $($ (risos) $/ \ldots /$ \\
\hline $\begin{array}{l}524 \\
525 \\
526 \\
527 \\
528 \\
529 \\
530 \\
531 \\
532 \\
533\end{array}$ & Walewska & $\begin{array}{l}\text { Né, porque eu fui uma pessoa muito...cuidada, muito } \\
\text { mimada. Então a prática, a vida, que é que...né...a } \\
\text { minha...>ah, dona Walewska, isso aqui é assim }<\ldots>\text { dona } \\
\text { Walewska<, compra um um carrinho pra eu ir no } \\
\text { supermercado porque o seu supermercado...é muito caro } \uparrow . \\
\text { Olha quanta coisa a gente trocou...quanto eu ganhei, porque } \\
\text { eu aprendi a ouvir...né? E claro, no casamento } \uparrow, \text { com a minha } \\
\text { sogra } \uparrow, \text { com os meus irmãos } \uparrow, \text { com os meus } \\
\text { sobrinhos } \uparrow . . . c l a r o, \text { com os meus alunos a gente já falou...mas } \\
\text { na minha vida? Sem dúvida alguma. }\end{array}$ \\
\hline
\end{tabular}

Entrevista, trecho 14

\begin{tabular}{|c|c|c|}
\hline $\begin{array}{l}534 \\
535 \\
536\end{array}$ & Vanessa & $\begin{array}{l}\text { Como você define, é assim, como você } \\
\text { define...definiria...define seus alunos? Assim, fale sobre seus } \\
\text { alunos, >como você define eles<? [Como você os enxerga?] }\end{array}$ \\
\hline 537 & Walewska & [É, os meus alunos] são apaixonantes, né? São assim, \\
\hline 538 & & colaboradores, são...eh...vivos, espertos...eh...criativos...e me \\
\hline 539 & & estimulam muito. Eu tenho, assim, um enorme carinho quando \\
\hline 540 & & eu penso neles./.../ Isso é uma coisa muito boa, né, porque você \\
\hline 541 & & trabalhar e gostar, né? Eu gosto daquela história do domingo \\
\hline 542 & & começar a pensar que que eu vou fazer, aí eu penso num que \\
\hline 543 & & vai me desafiar, que vai me encher $\uparrow$ a paciência, e que eu vou \\
\hline 544 & & em cima, eh, mas tudo isso, esse esse pensar assim, ah...eh...o, \\
\hline 545 & & o Pablo* vai ficar não sei o que, isso tudo é uma sensação boa, \\
\hline 546 & & é sim, é você trabalhar com gente. E, e me encanta, assim, o \\
\hline 547 & & jeito como eles se viram, como eles resolvem, como eles $\uparrow$ vão \\
\hline 548 & & fazendo as coisas, muitas vezes $\uparrow$ sem se dar conta...de que \\
\hline 549 & & estão fazendo $\downarrow$...né? Você deixar, eh, $\uparrow$ solto, no Jardim \\
\hline 550 & & 个Botânico, prá fazer uma $\uparrow$ pesquisa com um $\uparrow$ turista, e ele \\
\hline 551 & & voltar: ih, professora, falei com um cara que era da Escócia e \\
\hline 552 & & ele queria...e ele foi, ele falou, ele pediu licença, eu >não disse \\
\hline 553 & & como é que ele ia fazer<. Eu só deixei... \\
\hline
\end{tabular}




\section{Entrevista, trecho 15}

\begin{tabular}{|l|l|l|}
\hline 554 & Vanessa & Vai... \\
\hline 555 & Walewska & Não é uma coisa imediata, às vezes isso...claro, sempre é \\
556 & & construído mas em alguns $\uparrow$ grupos você consegue $\uparrow$ abrir a \\
557 & & porta, /.../, descobrir qual é a $\uparrow$ chave que entra ali e vai. Outros \\
558 & & grupos são mais resistentes, você precisa dar uma vo:lta...né? \\
559 & & Então é legal, porque é um desafio, entendeu, é legal por isso. \\
560 & & Não é uma coisa que eu faça $\uparrow$ mecanicamente porque eles não \\
561 & & vão suportar, né, porque na minha aula eles não esperam que \\
562 & & seja mecânico...nós temos esse compromisso, assim...não vai \\
563 & & ser mecânico. Então é sempre, é sempre desafiador, é \\
564 & & sempre...legal. Mas é isso...parceiros. \\
\hline
\end{tabular}

\section{2}

\section{Anexo II}

Conversa, trechos selecionados do encontro do dia 20 de dezembro de 2011

\section{Conversa, Trecho1}

\begin{tabular}{|c|c|c|}
\hline 1 & Vanessa & Na na linha 6 do que você fala... \\
\hline 2 & Walewska & 6 \\
\hline 3 & Vanessa & Na verdade é... número 10. Linha 10. \\
\hline 4 & Walewska & Número 10. \\
\hline 5 & Vanessa & Tá vendo? \\
\hline 6 & Walewska & Aham \\
\hline $\begin{array}{l}7 \\
8 \\
9\end{array}$ & Vanessa & $\begin{array}{l}\text { Aí fala: e o que eu vejo hoje é que faltava essa parte humana } \uparrow \text {, } \\
\text { que eu não conseguia...que a gente tá em inglês, então a } \\
\text { ma[téria inglês] }\end{array}$ \\
\hline 10 & & {$[\mathrm{Ah}$, sim certo $]$} \\
\hline $\begin{array}{l}11 \\
12\end{array}$ & Vanessa & $\begin{array}{l}\text { [Você fala inglês]...aí você foi falando, falou que não tinha } \\
\text { uma aproximação. }\end{array}$ \\
\hline 13 & Walewska & Com os alunos. \\
\hline $\begin{array}{l}14 \\
15 \\
16 \\
17 \\
18 \\
19 \\
20 \\
21\end{array}$ & Vanessa & $\begin{array}{l}\text { Com os alunos. Aí você continua: eu me lembro assim, de ficar } \\
\text { babando porque os professores de ciências, português, eles eram } \\
\text { muito próximos dos alunos. Eles conheciam muito. Aí eu achei... } \\
\text { interessante, porque, porque que você fala assim, que faltava } \\
\text { essa parte humana nas aulas de inglês...por causa - será que é por } \\
\text { causa do idioma? /.../ os professores das outras matérias, todos } \\
\text { tinham essa aproximação, só porque eles falavam português? } \\
\text { Será que todos eram...[exploratórios? Eu ach...] }\end{array}$ \\
\hline
\end{tabular}




\begin{tabular}{|c|c|c|}
\hline $\begin{array}{l}22 \\
23 \\
24 \\
25 \\
26 \\
27 \\
28 \\
29 \\
30 \\
31 \\
32 \\
33 \\
34 \\
35\end{array}$ & Walewska & $\begin{array}{l}\text { [Eu...eu...é...o que, o que] a minha visão } \\
\text { nessa época era assim: eu não me sentia próxima dos alunos, } \\
\text { porque eu tinha uma matéria para dar, principalmente na rede } \\
\text { particular, eu tinha uma matéria pra pra dar, eu era... cobrada...eh } \\
\text { por essa matéria e essa matéria me exigia o quê? O falar inglês, } \\
\text { os alunos também e ficar bem eh fixa, né, seguir bem o } \\
\text { conteúdo. E aí, em conversas com professores de ciências, de } \\
\text { português, como eles tem a língua, e a matéria - a minha visão } \\
\text { daquela época - ehhh a matéria era mais próxima. Ciências, por } \\
\text { exemplo, o professor vai pra pra biologia, pro corpo humano, } \\
\text { reprodução, então tá próximo...ehh português, as redações eh } \\
\text { oferecem essa aproximação, essa conversa com o professor, essa } \\
\text { proximidade. Era isso que eu sentia falta. Havia uma distância. } \\
\text { [Eu] sentia uma distância. }\end{array}$ \\
\hline $\begin{array}{l}36 \\
37 \\
38 \\
39 \\
40\end{array}$ & Vanessa & $\begin{array}{l}\text { [O que eu] } \mathrm{O} \text { que eu tinha entendido era que você...que tem } \\
\text { sempre aqueles professores...que normal... normalmente, } \\
\text { engraçado, são de matérias tipo matemática e física mesmo, } \\
\text { essas matérias mais difíceis...que eles costumam ficar amigos } \\
\text { dos alunos, né, e vc assim uma coisa meio... }\end{array}$ \\
\hline 41 & Walewska & [eh eu eu] \\
\hline $\begin{array}{l}42 \\
43 \\
\end{array}$ & Vanessa & $\begin{array}{l}\text { [Estranha], eu imaginei que fosse mais ou menos isso, aí eu } \\
\text { queria... }\end{array}$ \\
\hline $\begin{array}{l}44 \\
45 \\
46 \\
\end{array}$ & Walewska & $\begin{array}{l}\text { Exis - eu eu sei o que você tá falando e e vejo isso } \\
\text { também...assim, alguns >professores, por exemplo<, professor } \\
\text { homem, ele tem uma um }{ }^{\circ} \text { papel impor }\left[\operatorname{tante}^{\circ} \ldots\right.\end{array}$ \\
\hline $\begin{array}{l}47 \\
48\end{array}$ & Vanessa & $\begin{array}{llll}\text { homens }<\text {, isso é verdade }] & {[>\mathrm{E}} & \text { são } & \text { professores } \\
\end{array}$ \\
\hline $\begin{array}{l}49 \\
50 \\
51 \\
52\end{array}$ & Walewska & $\begin{array}{l}\text { [Porque a escola] tem muita mulher e e aí a presença o } \\
\text { homem a identificação, às vezes pelo futebol... né? Por essas } \\
\text { coisas, isso, esse elo existe, mas não é a isso que eu que eu } \\
\text { estava me [referindo] }\end{array}$ \\
\hline 53 & Vanessa & \\
\hline $\begin{array}{l}54 \\
55 \\
56 \\
57\end{array}$ & Walewska & $\begin{array}{l}\text { O que eu me referi é assim, os professores conheciam os alunos, } \\
\text { e eu não. Eu eu tinha assim, claro, você, eu tô dizendo, eu tô } \\
\text { falando de um modo geral, sempre tem um que se aproxima, e } \\
\text { [tal, né?] }\end{array}$ \\
\hline 58 & Vanessa & [Aham, aham] \\
\hline 59 & Walewska & Mas de um modo geral não, havia uma [distância]. \\
\hline $\begin{array}{l}60 \\
61\end{array}$ & Vanessa & $\begin{array}{l}{[/ \ldots /] \text { que a ma[téria em }} \\
\text { si] era uma coisa muito distante da rea[lidade deles }]\end{array}$ \\
\hline $\begin{array}{l}62 \\
63 \\
64 \\
65 \\
66 \\
67 \\
68 \\
69\end{array}$ & Walewska & $\begin{array}{l}\text { [isso] } \\
\text { [é...tinha] aquela história, } \\
\text { o inglês, né, nós vamos estudar inglês e, naquela época, o que se } \\
\text { fazia era isso, se exigia muito, né, você > decorava diálogo, } \\
\text { passava diálogo, procurava o diálogo, falava o diálogo<...então } \\
\text { a aula tinha aquilo, >que não tinha nada a ver com a vida<...né? } \\
\text { ou...tinha, mas eu não via. E isso me incomodava, eh...isso daí } \\
\text { mais ou menos que eu quis dizer }\end{array}$ \\
\hline
\end{tabular}




\section{Conversa, Trecho 2}

\begin{tabular}{|c|c|c|}
\hline 70 & Vanessa & E, na...depois, na segunda página, na linha....84 $4^{57}$ \\
\hline 71 & Walewska & Na linha 84...tá \\
\hline $\begin{array}{l}72 \\
73\end{array}$ & Vanessa & $\begin{array}{l}\text { é..cê colocou "é sempre priorizar o outro, numa época de } \\
\text { competição, de resultados", cê viu? }\end{array}$ \\
\hline 74 & Walewska & Uhum \\
\hline $\begin{array}{l}75 \\
76 \\
77\end{array}$ & Vanessa & $\begin{array}{l}\text { Eu tava pensando sobre...essa informação...e aí se você for } \\
\text { pensar bem, o priorizar...o outro não é um conceito da nossa } \\
\text { sociedade }\end{array}$ \\
\hline 78 & Walewska & [Exato] \\
\hline $\begin{array}{l}79 \\
80 \\
81 \\
82 \\
83\end{array}$ & Vanessa & $\begin{array}{l}\text { [né?] A nossa sociedade ela é extremamente individualista. A } \\
\text { gente trabalha e a gente molda os indivíduos desde crianças a } \\
\text { serem individualistas, você não prioriza o outro, pensa em } \\
\text { você, pensa em você sempre, cê tem que pensar em você, [não } \\
\text { é?] }\end{array}$ \\
\hline 84 & Walewska & $\begin{array}{lc} & {[e ́ . . .]} \\
\end{array}$ \\
\hline 85 & Vanessa & O que que você quer...[é sempre assim!] \\
\hline $\begin{array}{l}86 \\
87 \\
88 \\
89 \\
90 \\
91 \\
92 \\
93 \\
94 \\
95 \\
96 \\
97\end{array}$ & Walewska & $\begin{array}{l}\text { [e você estimula] a competição. Se você } \\
\text { estimula a competição você olha o outro como um obstáculo a } \\
\text { superar...né? Você não vai aprender com o outro, se eu tenho } \\
\text { que saber mais que o outro...cê não vai, cê vai deixar isso de } \\
\text { lado. Então é nesse sentido sim...e::.:.....a até é engraçado } \\
\text { porque a gente fala assim, como a prática exploratória é é } \\
\text { transgressora, se o que ela fala é de união, é de aprender com o } \\
\text { outro, é de ter qualidade de vida...não é isso que se busca? Mas } \\
\text { essa transgressão é nesse sentido. É:: a soci a nossa sociedade, } \\
\text { né, a sociedade capitalista, mas, mas enfim, é:: a nossa } \\
\text { sociedade estimula isso, competição, nós temos na escola, a } \\
\text { prova, né, sim, e você [vê mesmo] }\end{array}$ \\
\hline 98 & Vanessa & [Nós temos na vida $]$ \\
\hline $\begin{array}{l}99 \\
100 \\
101 \\
102 \\
103\end{array}$ & Walewska & $\begin{array}{l}\text { Temos que é:: preparar porque vai ser uma competição, porque } \\
\text { ele vai pro vestibular, tem criança out outro dia a gente } \\
\text { tava...naquele dia lá, sexta-feira, a:: Solange tava com a netinha } \\
\text { e quando ela foi no colégio, eles tavam preocupados com } \\
\text { vestibular mas a menina tem dois anos! } \uparrow\end{array}$ \\
\hline 104 & Vanessa & Ahhaha...men[tira] \\
\hline 105 & Walewska & {$[\mathrm{Pô}$, como assim?] } \\
\hline 106 & Vanessa & {$[/ \ldots /]$} \\
\hline $\begin{array}{l}107 \\
108 \\
109 \\
110 \\
111 \\
112 \\
113\end{array}$ & Walewska & $\begin{array}{l}{[\mathrm{Na} \text { creche }] \text {, ela tava falando, na }} \\
\text { creche...tavam preocupados...nem sei mais assim, qual, de } \\
\text { onde isso começou, mas o que eu gravei foi isso, a } \\
\text { preocupação... na creche, não pode isso, não pode aquilo, ou } \\
\text { faz isso, faz aquilo, já era visando o o vestibular, mas pera lá, a } \\
\text { criança tem dois anos, ela não vai pra escola pra vestibular de } \\
\text { nada, ela vai pra brincar, pra conhecer o outro, pra pra se }\end{array}$ \\
\hline
\end{tabular}

\footnotetext{
${ }^{57}$ A formatação da transcrição foi modificada no texto final, portanto a passagem discutida não menciona a linha correta.
} 


\begin{tabular}{|c|c|c|}
\hline $\begin{array}{l}114 \\
115\end{array}$ & & $\begin{array}{l}\text { socializar, né...enfim, é nesse sentido do outro, mas não era } \\
\text { isso que cê ia me pergun[tar...] }\end{array}$ \\
\hline $\begin{array}{l}116 \\
117\end{array}$ & Vanessa & $\begin{array}{ccc}\text { Não], era exatamente } & \text { isso. } & \text { Foi } \\
\text { exatamente isso que eu pergunt que eu ia perguntar. } & \\
\end{array}$ \\
\hline 118 & Walewska & [Porque eu vi] \\
\hline $\begin{array}{l}119 \\
120 \\
121 \\
122\end{array}$ & Vanessa & $\begin{array}{l}\text { [Porque como] é um soci...co como é um conceito que é } \\
\text { completamente, que que é é um conceito muito oriental, não é } \\
\text { um >conceito da sociedade ocidental }<\downarrow \text {, eu pe - é isso mesmo } \\
\text { que ela quer dizer? É priorizar mesmo? }\end{array}$ \\
\hline $\begin{array}{l}123 \\
124\end{array}$ & Vanessa & $\begin{array}{l}\text { [Porque] é [> uma coisa realmente<], não é do con[ceito da } \\
\text { sociedade... }\end{array}$ \\
\hline $\begin{array}{l}125 \\
126 \\
127 \\
\end{array}$ & Walewska & $\begin{array}{l}\text { [É::] [Priorizar] } \\
\text { assim, eu tenho que ter respeito, e isso realmente...é } \\
\text { meio...oriental, [né?] }\end{array}$ \\
\hline 128 & Vanessa & [Uhum] \\
\hline $\begin{array}{l}129 \\
130 \\
131 \\
132 \\
133 \\
134 \\
135 \\
136 \\
137 \\
138 \\
139 \\
140 \\
141 \\
142 \\
143 \\
144 \\
145 \\
146 \\
147 \\
148\end{array}$ & Walewska & $\begin{array}{l}\text { Eu tenho que ter respeito por você, já que eu vou aprender com } \\
\text { você, e nós vamos construir alguma coisa juntos. E nós vamos } \\
\text { construir para que prá gente viver melhor, prá a nossa } \\
\text { qualidade de vida ser melhor... E isso é muito difícil na escola, } \\
\text { pela idade, né, porque eles tão numa idade, eles querem } \\
\text { sobressair, eles querem...é...eles são egoístas, né...mas, isso não } \\
\text { quer dizer que a gente consiga, assim, no sentido da perfeição, } \\
\text { mas quer dizer que a gente trabalhe para isso, toda a história da } \\
\text { Prática Exploratória é o trabalhar para, não é o conseguir...né? } \\
\text { mas quando você trabalha para, você tá leva:.:.ndo em } \\
\text { consideração...o outro. Você tá trabalhando junto para ter uma } \\
>\text { boa qualidade de vida<, e como é que você vai ter isso? Não é } \\
\text { competindo! Certamente! Mas é ouvindo o outro, escutando o } \\
\text { outro, aprendendo o outro, seja esse outro o professor, seja o } \\
\text { seu colega...e vice-versa, o professor também...né, então é... } \downarrow \\
\text { por isso é que eu digo, enfim, eu achei também que isso não } \\
\text { tava claro, eu li e falei assim, mas como é transgressora? Como } \\
\text { a prática exploratória é transgressora, se ela...ela não tá } \\
\text { transgredindo se ela diz que é qualidade de vida, que é ouvir o } \\
\text { outro...mas, no contexto que a gente vive, isso é transgredir. }\end{array}$ \\
\hline $\begin{array}{l}149 \\
150 \\
151\end{array}$ & Vanessa & $\begin{array}{l}\text { O modo como é feito, né? Eu acho que a gente busca qualidade } \\
\text { de vida mas assim...na sociedade, mas é um outro viés, é um } \\
\text { viés [competitivo]. }\end{array}$ \\
\hline 152 & Walewska & \\
\hline 153 & Vanessa & A nossa qualidade de [vida. $>\mathrm{O}$ con]ceito é outro $<$. \\
\hline 154 & Walewska & [é outro] \\
\hline 155 & Vanessa & $>\mathrm{O}$ [conceito é outro<,exatamente]. \\
\hline 156 & Walewska & \\
\hline
\end{tabular}




\section{Conversa, Trecho 3}

\begin{tabular}{|c|c|c|}
\hline $\begin{array}{l}157 \\
158 \\
159 \\
160 \\
161 \\
162 \\
163\end{array}$ & Walewska & $\begin{array}{l}\text { Vai se formar, vai botar na fôrma. Então se bota na } \\
\text { fôrma...botou, sabe, a quantia exata, vai ficar ali. É nesse } \\
\text { sentido, é::, eu, aqui, eu tava falando...dessa destrava, é...de eu } \\
\text { poder formular, d'eu refletir, falar, né, e nesse contexto aqui, } \\
\text { num conselho de classe, todo mundo...têm idéias mais } \\
\text { fechadinhas, ou não...não se permite dizer, né...nesse sentido, } \\
\text { mas no sentido mais amplo, é a mesma coisa. }\end{array}$ \\
\hline $\begin{array}{l}164 \\
165\end{array}$ & Vanessa & $\begin{array}{l}\text { É a mesma coisa, a educação travou e >ainda continua } \\
\text { travando }<\ldots \text {... [né?] }\end{array}$ \\
\hline $\begin{array}{l}166 \\
167 \\
168 \\
169\end{array}$ & Walewska & $\begin{array}{l}\text { [quando você pergunta pro aluno o que é que você } \\
\text { acha, quando você tenta dialogar, negociar...nem sempre o } \\
\text { aluno entende isso, então ele pode entender que ah, com ela } \\
\text { qualquer coisa serve, ela é muito [boazinha]. }\end{array}$ \\
\hline $\begin{array}{l}170 \\
171\end{array}$ & Vanessa & [Eu ficava confusa], como aluna. \\
\hline 172 & Walev & [ele fica confuso] \\
\hline 173 & & Mas eu não tenho que saber, quem tem que [saber é você]. \\
\hline 174 & Walewska & [haha exatamente] \\
\hline
\end{tabular}

\section{Conversa, Trecho 4}

\begin{tabular}{|c|c|c|}
\hline $\begin{array}{l}186 \\
187 \\
188 \\
189 \\
190 \\
191 \\
192 \\
193 \\
194 \\
195 \\
196 \\
197 \\
198 \\
199\end{array}$ & Walewska & $\begin{array}{l}\text { O que, o que é...me encantou muito nessa história da eficiência } \\
\text { é porque obviamente eu buscava eficiência, eu queria ser uma } \\
\text { professora melhor, né...eu queria, é, que as aulas fossem } \\
\text { alguma coisa...excepcional...é...e quando eu li Allwright ele } \\
\text { diz, não se preocupe com a eficiência, procure entender. } \\
\text { Porque quando você entende o que tá acontecendo na sua } \\
\text { sala...se o aluno chegou atrasado...porque o ônibus...não } \\
\text { chegou...ele veio da Rocinha, até chegar aqui, ele chega } \\
\text { atrasado...se ele tá cansado porque ele trabalhou à noite...se } \\
\text { todas essas coisas humanas fazem parte da sua aula também, } \\
\text { você não tá buscando essa eficiência de resultado, mas você tá } \\
\text { buscando essa eficiência do entendimento e essa eficiência do } \\
\text { ser humano, porque eu entendi você, eu entendi o outro. Nesse } \\
\text { momento ele não pode mas isso não quer dizer que eu vá } \\
\text { desistir dele, eu vou apresentar de um outro jeito, eu vou...é:.: } \\
\text { eu vou buscar uma outra coisa, né? Se o aluno, eu sei, naquele } \\
\text { momento ele não pode fazer mas ele não quer dizer que ele não } \\
\text { queira fazer. Eu não vou simplesmente rotular: ele é chato, ele } \\
\text { é burro, ele não sabe, ele não faz, ele não quer...eu tenho que } \\
\text { tentar entender, ou busca::r uma saída, ele precisa de um } \\
\text { acompanhamento...né? Mas eu vou ter um olhar, pra ele, } \\
\text { humano. Então é nesse sentido porque quando você começa a } \\
\text { ver por isso, Vanessa, você querendo ou não você se aproxima } \\
\text { da eficiência...né? Não, talvez, do 10, do índice, do tal, mas da } \\
\text { eficiência do ensino libertador...né, não do que trava. O que }\end{array}$ \\
\hline
\end{tabular}




\begin{tabular}{|c|c|c|}
\hline $\begin{array}{l}200 \\
201 \\
202 \\
203\end{array}$ & & $\begin{array}{l}\text { trava é do índice. Mas o que liberta. Porque ele entendeu } \\
\text { também, ah, nesse momento não dá pra eu fazer, /.../, meus } \\
\text { pais brigaram, meu pai saiu de casa, minha mãe casou de } \\
\text { novo...[né?] }\end{array}$ \\
\hline $\begin{array}{l}204 \\
205\end{array}$ & Vanessa & $\begin{array}{l}\text { [Acho que o mais importante é eles terem a consciência] } \\
\text { da sociedade [em que eles estão] e saber o que realmente }\end{array}$ \\
\hline 206 & Walewska & [mas eu posso] \\
\hline 207 & Vanessa & $\begin{array}{l}\text { Precisam saber e o que não precisam. O que vai fazer... } \\
\text { importância na vida deles o que não vai ter. }\end{array}$ \\
\hline 209 & Walewska & Exat- mas que ele é capaz. \\
\hline 210 & Vanessa & Não, sim. \\
\hline 211 & Walewska & Ele é capaz. Eu acho que é li[dar] sempre com isso. \\
\hline 212 & Vanessa & {$[$ [é:::] } \\
\hline $\begin{array}{l}213 \\
214 \\
215\end{array}$ & Walewska & $\begin{array}{l}\text { Nasceu gente inteligente e vamos em frente e...hoje não deu } \\
\text { amanhã vai dar e vamos estimular e isso também reflete em } \\
\text { você. Isso é uma coisa assim, é é um [um..]. }\end{array}$ \\
\hline 216 & Vanessa & [Retro]alimentação. \\
\hline $\begin{array}{l}217 \\
218 \\
219 \\
220 \\
221 \\
222 \\
223 \\
224 \\
225\end{array}$ & Walewska & $\begin{array}{l}\text { É, é...exatamente. Realimenta. Exatamente isso. Você se } \\
\text { sente...cê tá fazendo alguma coisa, você tá: produzindo, mesmo } \\
\text { que...mas ele só tirou } 3,5 . . . \text { mas e no outro ele vai tirar } 4,5 \\
5,5 \ldots \text { mas quanta coisa rica aconteceu, né? Cê tem que entender. } \\
\text { Eu...é:::eu tava conversando com um rapaz Marcelo*, que tá } \\
\text { fazendo...é especialização, eu tava contando, que é muito } \\
\text { engraçado, eu acho >não sei já falei isso com você<, eu tenho } \\
\text { uma aluna da tarde que a gente conversa ao contrário ( } 22: 56) \text {, } \\
\text { ela passa por mim e fala assim: hoje não vou assistir sua aula... }\end{array}$ \\
\hline 226 & Vanessa & Ah::::, já sei, você já me falou dela \\
\hline \begin{tabular}{l|l}
227 \\
228 \\
229 \\
230 \\
231 \\
232 \\
233 \\
234 \\
235 \\
236 \\
237 \\
238 \\
239 \\
240
\end{tabular} & Walewska & $\begin{array}{l}\text { Então, é interessante porque...ela funciona } \uparrow \text { assim. A chave } \\
\text { dela, isso que abre, é assim, é o } \downarrow \text { contrário. Ela é } \\
\text { emburradinha, ela é fechadinha, mas não é isso. No final, no } \\
\text { final do ano eu recebi um trabalho dela cheio de coração, e a } \\
\text { gente se beijou, de vez em quando a gente depois que a gente } \\
\text { falava todas essas coisas: >eu não gosto de você, não gosto de } \\
\text { você, você tá feia, você não sei que<, aí a gente se beija e tal, e } \\
\text { aí aquilo destrava. Então, isso, é nesse sentido do entender que } \\
\text { você vai chegar à eficiência, não busca só a eficiência, procura } \\
\text { entender. Porque se for eficiência que você tá buscando, você } \\
\text { vai chegar a ela por outros caminhos e essa eficiência, ela vai } \\
\text { se abrir para vários significados, né? Não é só a nota, o passar, } \\
\text { o finalizar, mas é nesse sentido. É um pouco complicado } \\
\text { [mas]... }\end{array}$ \\
\hline 241 & Vanessa & [não, não] Eu gostei do exemplo \\
\hline 242 & Walewska & De [explicar] \\
\hline 243 & Vanessa & [Foi be::m legal] \\
\hline 244 & Walewska & É complicado de explicar. Mas não é de entender. \\
\hline
\end{tabular}




\section{3}

\section{Anexo III}

Comunicação pessoal, via e-mail, dia 14/09/2011, quando pedi para Walewska escrever um relato sobre o pôster Angels, Vampires e Caspers, que já esteve presente em várias exposições da PE.

\section{Quem é o meu aluno?}

O pôster foi desenvolvido e feito com e por meus alunos de 8 a série do ensino fundamental da escola municipal Cócio Barcelos . Nova na escola, eles me foram apresentados como um grupo de adolescentes repetentes desinteressados, indisciplinados...

Comecei com uma questão que deu lugar a outras, consequência de um trabalho de observação e reflexão que aos poucos nos envolveu (alunos e professora).

Meu questionamento inicial foi: "Por que meus alunos só se interessam por notas?" Eu queria entender por que meus alunos separavam as atividades de aula das de avaliação; por que se comportavam de modo tão diverso nos dois momentos; se eles estavam eles aprendendo alguma coisa...

Para observá-los preparei duas atividades pedagógicas comuns à nossa prática de sala de aula; um exercício (sem nota) para aula, e um teste - surpresa. Ambos continham YES/NO questions preparadas de acordo com o que eu observava quanto à atitude deles em sala de aula. E os dados que colhi foram: durante o exercício os alunos conversavam, jogavam, comiam, ouviam 'walkman'; durante o teste eles estavam concentrados, calmos e atentos.

No entanto as notas do teste foram boas e eu não podia dizer que os alunos, apesar do jeito informal e relaxado de assistir às aulas, não tinham aprendido nada. Comecei a perceber que os alunos podiam comer um biscoito enquanto aprendiam e que eu só ficaria mais e mais estressada se tentasse impor atitudes totalmente sem significado para eles. Eu refletia e as coisas aconteciam...

Levei meus alunos ao cinema para assistir o filme Policarpo Quaresma, parte do projeto "Indo ao Cinema". Pude então observar que no escurinho do cinema eles não se "comportavam": falavam alto, ficavam em pé, iam ao 
banheiro, comiam... se comportavam do mesmo modo que agiam nas minhas aulas. Eu saí com a certeza de que eles não tinham prestado a mínima atenção.

Para minha surpresa, o grupo do projeto encarregado da discussão veio à minha sala e os meus alunos não apenas sabiam a estória como fizeram comentários pertinentes e críticos comparando os políticos da época aos políticos de hoje. Como poderia eu negar que eles aprenderam - e muito bem- a lição ensinada? E algo começava a me inquietar: "Por que eu não conseguia entender $e$ aceitar a maneira que os meus alunos tinham de participar nas minhas aulas"?

E não era fácil aceitar a falta de concentração, a inquietação, a "bagunça"... No meio de uma bronca uma aluna disparou... "Professora, o problema é que você gostaria de dar aulas para anjos e nós... somos uns demônios!” Foi um momento poderoso! Pela primeira vez eu fui capaz de dar voz e de ouvir meu aluno!!!

E, assim, começando a aprender que meus alunos tinham muito a me dizer, decidir investigar, com eles, uma nova questão: 'Quem é o meu aluno?' Passei uma nova tarefa: um trabalho em grupo. Pedi que assinalassem as afirmações com que concordassem. Eles também poderiam resumir suas idéias através de um desenho. Analisando as respostas pude ver que meus alunos já tinham percebido (ah, então eles observam, refletem!!!!) que eu gostaria que eles se comportassem "bem": Eu esperava que eles copiassem os exercícios do quadro, fizessem os exercícios, perguntassem, tirassem dúvidas. Eles não deveriam comer, dormir ou falar! Um dos grupos tornou as coisas mais claras ainda ao desenhar a diferença entre nossos pontos de vistas. Segundo os desenhos, eu queria anjos. E eles eram demônios que não queriam fazer nada além se conversar, comer, brincar, se divertir.

$\mathrm{Na}$ época eu estava trabalhando com os verbos no Imperative Form e preparando o próximo ponto gramatical: Simple Present. Aproveitei a oportunidade e o grande interesse deles para trabalharmos com o vocabulário que eles queriam usar, advérbios de freqüência, formas afirmativas e negativas dos verbos no Simple Present Tense.

“Anjos", disseram eles, não conversam, não comem na sala, são educados, chegam sempre na hora, estudam e fazem dever de casa. "Demônios/vampiros" nunca estudam, ficam nos corredores, colam nas provas, matam aula, comem 
biscoito, balas, chiclete durante a aula. Das nossas reflexões vimos que, com alguma negociação, poderiam surgir os "Caspers", fantasminhas camaradas. "Caspers" conversam... mas fazem os exercícios, trazem "walkman" para a sala, mas só ouvem quando é possível, tentam não colar, são educados, fazem o dever de casa... algumas vezes.

Todas estas características foram sendo usadas para formar frases em inglês: angels get very good grades; angels don't chew gum; vampires cheat in tests; vampires never study; caspers avoid cheating; caspers sometimes do their homework. ${ }^{58}$

Nessa época meus alunos já sabiam que eu falava deles e dos nossos entendimentos nas reuniões quinzenais de PE e é claro que eles se sentiam muito importantes. Com o aumento de auto-estima cresceu o interesse deles na aula de inglês. Pedi que eles desenvolvessem a idéia de ANJOS X DEMÔNIOS em pôsteres para que fossem apresentados a outros professores. Como estávamos em outubro, o mês do Halloween, os demônios foram representados por uma abóbora que contrastava com um anjo.

E eles iam aprendendo vocabulário de um modo interessante e cheio de significado: eles aprendiam o que eles queriam dizer. Eles não paravam quietos, faziam muito barulho, mas como trabalhavam!

E o pôster evoluía: meus alunos não eram anjos. Mas também não eram demônios. Eles eram como o GASPARZINHO, o fantasminha camarada. Meus gasparzinhos me ensinaram muito. Parei de me preocupar com a disciplina e outras idéias que só faziam sentido na minha época escolar, quando reflexão, pensamento crítico, autonomia não eram estimulados e sim reprimidos. Afinal, o que há de errado em se comer um biscoito enquanto se copia o exercício do quadro?

Fomos além...Convidei meus gasparzinhos a observarem e pesquisarem nossa escola. Com uma máquina fotográfica pedi-lhes que procurassem anjos, demônios e gasparzinhos na escola. E eles me trouxeram uma turma de anjos; alunos de 5 anos e uma professora muito severa. A turma ao lado da sala deles representava os demônios: desassossegados e barulhentos. E os gasparzinhos? Não me surpreendi quando eles me mostraram a foto da turma deles.

\footnotetext{
${ }^{58}$ Anjos tiram ótimas notas, anjos não mascam chicletes, vampiros colam nas provas, vampiros nunca estudam, garparzinhos evitam colar, gasparzinhos às vezes fazem o dever de casa.
} 


\section{4}

\section{Anexo IV}

Artigo sobre educação publicado em 15 de dezembro de 2012 em $<$ http://exame.abril.com.br/economia/mundo/noticias/4-fatos-curiosos-que-fazemda-educacao-na-finlandia-um-exemplo>

\section{4 fatos curiosos que fazem da educação na Finlândia um exemplo}

\section{Lição de casa e boas notas têm pouco peso no sistema educacional altamente} bem-sucedido dos finlandeses

São Paulo - A Finlândia tem um dos sistemas educacionais mais admirados do mundo. O país garante acesso universal e gratuito a escolas de qualidade e está em primeiro lugar no índice de educação global publicado pela ONU em 2008.

Como parte de uma reforma no ensino feita na década de 1970, o país paga melhores salários aos professores, limita o número de alunos em sala de aula, garante liberdade às escolas para trabalhar o próprio currículo e dá pouca atenção a avaliações e dever de casa.

O resultado pode ser medido em números: segundo dados de um levantamento feito pelo instituto Legatum, 94\% dos finlandeses aptos concluem o ensino secundário e ingressam no ensino superior. A mesma pesquisa mostra que $82 \%$ dos finlandeses estão satisfeitos com a qualidade da educação no país.

Confira, a seguir, quatro fatores pouco familiares à realidade do ensino brasileiro que contribuem para estes resultados:

\section{A escola só começa aos 7 anos de idade e, lição de casa, só na adolescência}

Segundo a OECD (Organização para a Cooperação e Desenvolvimento Econômico), as crianças finlandesas são as que passam menos horas dentro de sala de aula entre os países desenvolvidos. Embora existam creches e pré-escolas, a educação formal só começa aos 7 anos de idade - a ideia é que antes desta idade elas aprendem melhor brincando que em sala de aula - e os graus primário e secundário são integrados para que a criança não tenha que trocar de escola no meio do processo. Os “intervalos" podem, durar até 75 minutos e a lição de casa 
não é uma prática incentivada antes que os alunos cheguem ao meio da adolescência, por volta dos 16 anos de idade.

\section{Os alunos não são avaliados por notas}

Uma das características marcantes do sistema educacional finlandês é o alto grau de autonomia concedido a escolas e professores. Não há nenhuma avaliação padrão obrigatória para os alunos a não ser por um único teste de língua, matemática e ciências naturais ao final do ensino secundário (quando os alunos têm entre 17 e 19 anos de idade). No dia a dia, os professores não avaliam os alunos por notas e sim por critérios descritivos, evitando comparações entre eles. Assim, o foco não é no desempenho dos alunos e sim do aprendizado de fato.

\section{Todos os professores têm mestrado}

Os professores fazem parte de uma categoria altamente prestigiada na Finlândia. Para poder ingressar no sistema de ensino - inclusive na educação básica - é necessário ter um mestrado. A seleção não é fácil: apenas $10 \%$ dos 5 mil candidatos que participam das provas todos os anos são aceitos pelas faculdades. E mesmo depois de pós-graduados, os professores continuam a se reciclar. Um professor passa, em média, 4 horas por dia em sala de aula e reserva duas horas semanais para se dedicar ao "desenvolvimento profissional".

\section{$30 \%$ das crianças recebem reforço fora de sala de aula}

Se no Brasil reforço é visto como coisa de aluno preguiçoso ou atrasado em relação à turma, na Finlândia a ajuda extra classe é uma prática comum. Cerca de $30 \%$ dos alunos recebem algum tipo de atenção especial fora do horário de aula durante seus nove primeiros anos de educação formal. Muitas escolas são pequenas o suficiente para que os professores conheçam cada aluno pelo nome. Enquanto no Brasil a média é de 23 alunos por professor em sala de aula, na educação primária, na Finlândia a média é de 14 alunos por professor. 


\section{5}

\section{Anexo V}

Anotações e reflexões pessoais sobre as aulas que assisti. As aulas foram assistidas sempre às sextas-feiras, em dois tempos da manhã, cada tempo em uma turma diferente. Em negrito constam as anotações da professora Walewska Braga, que teve acesso a esse "diário", no intuito de trabalharmos juntas para entendermos as salas de aula observadas.

Dia 26 de agosto de 2011

\section{$\underline{\text { Turma } 1(08 \mathrm{~h})}$}

Assim que eu cheguei, o quadro estava cheio de perguntas em inglês. A professora havia avisado da minha visita e eles estavam fazendo um "brainstorming” das perguntas que eles iriam me fazer (a aula se inicia às 07h10). Me fizeram perguntas o tempo inteiro, e eu comecei a responder em inglês. Eles se agitaram, falavam que não entendiam. Então eu comecei a gesticular e um aluno tentava traduzir o que eu falava. Depois olhava para mim para confirmar se o que ele havia dito estava correto. E, na maioria das vezes, estava. Quando não estava, eu traduzia para o português.

$\mathrm{E}$ assim foi a aula inteira (50 minutos)...eles estavam muito interessados e gostavam muito de me ouvir falando inglês. Foi muito agradável.

\section{$\underline{\text { Turma } 2(8 \mathrm{~h} 50)}$}

$\mathrm{Eu}$ me apresentei em inglês, e depois traduzi para o português. Eles fizeram poucas perguntas. Comecei respondendo em inglês também, e rapidamente uma aluna se dispôs a traduzir. Ela fazia curso de inglês e se saiu bem.

Após uns 10 minutos eles iniciaram a atividade em grupo que havia sido interrompida na aula anterior.

Para essa tarefa, eles tinham que procurar algumas palavras no dicionário. Um grupo de meninos lá atrás parecia ignorar a presença da professora, e estavam sentados displicentemente, jogando cartas. Walewska se dirigiu a eles e pediu que eles fizessem a atividade, e então eles começaram a fazer, utilizando o celular para procurar a tradução das palavras (com o Google translator). Achei interessante como tudo isso se deu: a professora, ao invés de lhes dar uma "bronca" em voz 
alta, se dirigiu até o grupo após todos os demais já terem iniciado o trabalho e, com a voz mansa e baixa que lhe é característica, pediu-lhes para que guardassem o jogo. Os três meninos prontamente atenderam ao pedido da professora e se engajaram no trabalho até o fim da aula. Achei fantástico o cuidado que a professora teve de não expor os alunos, e também o fato de os alunos não oferecerem resistência ao pedido da professora, como também é muito comum. Isso mostra (em minha opinião), que eles estavam jogando cartas não para "desafiar a professora", como poderia ser interpretado, mas simplesmente porque estavam entretidos no jogo e, adolescentes que são, queriam continuar dedicandose à atividade. A professora pediu, eles atenderam, sem ofensas ou maiores traumas. Como sou professora também, a forma pacífica com que tudo isso se passou chamou imensamente minha atenção, pois já vi coisas muito distintas acontecerem...

A aula terminou com eles ainda fazendo a atividade, que precisou ser interrompida, e seria finalizada ainda no dia, no último tempo de aula.

Relendo e relembrando...

Temos aí umas coisitas a pensar, é claro...

O que eu queria naquelas aulas? Ora, aproveitar a oportunidade que me caiu do céu exploratório...uma visita que só aumentaria auto estimas (de alunos e professora) e mostraria para que serve o to be do dia a dia! Mas, é claro, cada turma tem seus interesses e a reação foi diferente em cada uma. A 1802 adorou, participou, vibrou com a possibilidade de descobrir quem a visita era...A 1902, mais low profile, mais 1902 mesmo, agiu normalmente (ou pelo menos assim pareceu). Legal, novidade, e aí, vamos em frente...

$O$ "incidente" com os meninos que tanto chamou a sua atenção e que ve tão bem percebeu tem a ver, é claro, com a adolescência e o meu modo de lidar com isso vem da minha “exploratorescência????”. Eu entendo que eles relutem em trabalhar. Mas está na hora de estudar, então...vamos conversar, negociar, envolver. Ouvindo meus alunos aprendi que bater de frente gera stress e nada mais.

Aí passam questões como o planejamento do professor e individualidades (dos alunos e da turma) e as maravilhosas learning opportunities que o dia a dia traz. Let's enjoy them!!!!! 
Dia 02 de setembro de 2012.

\section{$\underline{\text { Turma } 1}$}

Assim que eu entrei na sala a professora começou a se dirigir a mim e a falar, em voz alta para a turma ouvir, o que eles estavam fazendo. Disse que a turma estava muito intrigada com o "mistério do mural", pois os trabalhos que eles faziam e colocavam no mural desapareciam misteriosamente.

Então, a professora perguntou-lhes porque, na opinião deles, as coisas desapareciam do mural, e eles responderam prontamente: "é a outra turma que rasga", "são eles", etc. Em nenhum momento me pareceu haver dúvida ou vontade de comprovar se foram os outros alunos mesmo que danificaram o mural. Eles sequer levantaram a hipótese de dar aos acusados o benefício da dúvida, ou de pesquisar, assumindo que os alunos acusados fossem mesmo os culpados, o porquê de eles agirem assim. Eles já sabiam a resposta: "são vândalos e maleducados".

Foi a professora quem suscitou essas questões e pediu que eles se dividissem em grupos e perguntassem a quem eles quisessem na escola (inspetores, professores, colegas, diretora), a opinião deles sobre a destruição do mural (porque eles achavam que isso acontecia, quem eram os responsáveis etc).

Bem, eu trabalhava com a turma da tarde também e sabia que eles nada tinham a ver com a destruição do mural (que não acontecia pela $1^{a}$ vez, não!!!). O que me incomoda muito na escola é essa mania de achar que o outro é o culpado! A escola trabalha sempre assim, julgando, condenando, rotulando, separando... Nos COCs é assim tb, professor, coordenador, sempre dizem que turma da tarde é assim, são sem educação, não querem nada! E a escola vive dividida... Nossos alunos são adolescentes, são nossos alunos!!!! E eu sei que os alunos são amigos uns dos outros e fazem o joguinho que aprenderam. Não fui eu, foi o outro, eu fiz porque ele fez e você não fez nada, agora briga comigo. Aprenderam na e com a escola!... Quantas vezes ouvimos do professor: Eu ensinei, ele não aprendeu porque não estudou, a culpa é da mãe e assim vamos... 
Apesar de entender a proposta de trabalho, não achei a atividade exploratória pois não partiu de um "puzzle" dos próprios alunos. Eles já tinham a resposta para a questão e já haviam feito seu juízo de valor.

Entretanto, pode ser que a professora tenha feito isso de modo a despertar nos alunos a consciência de que havia a possibilidade de outras respostas para o "mistério do mural", como a professora chamou. Mas, como eu disse anteriormente, para os alunos não parecia haver mistério.

Bem, Vanessa, era uma questão minha mesmo, com muitas possibilidades de trabalhar para entender, pois ia além do mural. E eu sempre aproveito...

O que é um mural de escola? Um lugar para o quê mesmo? O professor mostrar que trabalha para o dia em que a CRE visitar a escola. Então a professora II (das $1^{a}$ s séries) se mata fazendo, fica bonito. O aluno não está nem aí, não é dele, é feito com o trabalho dele... Mais tarde, já crescido, ele não quer pendurar o trabalho, e por que o faria???? Do outro lado, a direção e a coordenação pedem para que os professores façam o mural. Alguém faz. O aluno não liga. Vai lá, cola para a professora ficar feliz ou para ganhar nota. E assim vamos, ninguém discute isso. Será que a sala precisa de mural???? Por quêe?? Para esconder a pintura descascada. Porque alguém disse que mural faz parte da ambientação escolar... Cada coisa...

Mas o interessante e inesperado (?!) é que o mistério terminou quando a professora da sala de leitura me disse que achou o mural da 1801 tão lindo que retirou da sala antes que os vândalos destruíssem e deixou na sala de leitura... Meu Deus!!!!! Isso é possível???? Só em escola mesmo...O mistério acabou mas as questões ficaram!!!

Eu me lembro que uma das alunas foi comigo para uma das reuniões da PE conversamos todos sobre o assunto. Ela disse que os alunos costumam mandar mensagens para os amigos pelo mural (os da manhã para os da tarde e viceversa, mensagens como: eu adoro vc, estou com saudades, beijos). Olha que legal!!!! Acho que a Bebel sugeriu que a escola tivesse um local para isso. Vimos também, através da pesquisa do grupo da menina, como os professores lidam com o problema do mural (sim, a questão existe, é questão da escola, é da vida, é a pichação que tanto nos incomoda...) ; uma professora entrevistada 
disse que quando o mural da sala é pichado e ela descobre os autores, faz um teste de verbos como punição... Мuиuиuиuиuuиuuuito educativo!

Viu com a questão é exploratória e riquíssima?

Quanto ao livro eles têm razão: é chato mesmo... Curioso como nós agimos do mesmo modo: é chato, mas se temos que fazer...tal professora, tal alunos...

\section{Turma 2}

Eles iniciaram um trabalho sobre amizade (Friendship Project). A professora já havia introduzido o assunto na aula anterior, e eles se dividiram em grupos. A professora também já havia coletado depoimentos dos alunos sobre amizades especiais que eles haviam feito na escola. Todos os alunos receberam uma folha com essas frases, e, apesar de a professora ter tomado o cuidado de não identificar nem os autores das frases nem os amigos que eram mencionados, os próprios alunos foram, aos poucos, se identificando espontaneamente como autores das frases. $\mathrm{O}$ resto da turma naturalmente passou a tentar adivinhar a qual aluno eles se referiam em seu depoimento e pareciam se divertir com isso. No final, todas as identidades foram reveladas. Discutiram-se ali situações interessantes, de amizades que surgiram onde antes havia uma implicância, por exemplo, ou preconceito, tabu. Os alunos se mostraram conscientes a respeito de questões em voga no momento, como o bullying, e das consequências negativas que tal atitude gera.

Após a discussão inicial, os grupos iniciaram as tarefas (listadas em uma folha). Uma das tarefas era procurar verbos relacionados à amizade no dicionário. Depois, escrever frases e fazer um pôster sobre amizade para colocar no mural. A professora me incentivou a participar mais ativamente, dizendo aos alunos que eles poderiam tirar dúvidas comigo. Não houve tempo para o término da atividade.

P.S. Houve um grupo que chegou depois de uns 15 minutos de a aula ter se iniciado. Não ficaram muito engajados durante a atividade. Era um grupo grande, uns sete alunos. A professora tentou dividir o grupo mas, na prática, apenas dois alunos (os que estavam responsáveis pela folha de papel que deveria ser entregue à professora), efetivamente pareciam se dedicar. 
Os relatos foram lindos, bem escritos e eu me emocionei ao lê-los. Muitos alunos se conheciam desde pequenos, uma vida juntos; outros chegaram mais tarde e todos tiveram importância na vida de todos. Os professores também deram depoimentos bonitos; as amizades que perduram até hoje, as amizades da escola que vão além da escola. As situações de sala de aula: as injustiças que levam uns a defenderem os outros e até amigo oculto organizado pela professora, que fez com que alunos que não se falassem se tornassem amigos para sempre... Riqueza de material!!!!

Dia 09 de setembro de 2011.

\section{$\underline{\text { Turma } 1}$}

A professora perguntou sobre o resultado da pesquisa sobre o mistério do mural. A maioria da turma não havia feito a pesquisa, mas havia um grupo que havia feito, e sua representante estava bastante engajada e interessada em falar sobre suas descobertas (que na verdade pareceram ratificar o pré-julgamento que já havia sido feito pela turma). Ela disse que nenhum dos entrevistados sabia ao certo o que acontecia com o mural, e que a diretora não havia sido localizada para a entrevista. Com tudo isso, ela acreditava fortemente que os únicos culpados possíveis eram os alunos da outra turma.

Conversamos todos (a turma) um pouco sobre isso e depois a professora trabalhou com os livros e pediu que eles fizessem alguns exercícios (e todos reclamaram). Assim foi até o fim da aula. Os alunos pediam muita ajuda com tradução, falavam que não sabiam inglês e que preferiam os trabalhos. Interessante, eu achei. Eles efetivamente gostam de trabalhar em conjunto, acho que a escola deveria valorizar mais isso.

Uma característica desse grupo é a criatividade. Eles são realizadores e gostam de trabalhar. Em grupo, melhor... Se eles trabalham, que legal!!! E gostam muииииииииииииito de conversar, de perguntar, são geniais... Aprendi muito com eles!!! Trabalhar em grupo é tão importante... Como gerenciar as tarefas? O tempo? Onde pesquisar? Quem faz? São tantas coisas a considerar... Eu apoio!!!! 


\section{Turma 2}

Os alunos se organizaram em grupos para terminar o trabalho da semana passada. Como eles solicitavam bastante nossa ajuda, a professora resolveu criar um “information counter", ou "balcão de informações". Nós duas ficamos sentadas no meio da sala e os alunos que quisessem poderiam se dirigir a nós e pedir informações (para incentivar um mínimo de proatividade). Assim foi até o fim da aula, com alunos engajados e participantes. A última tarefa era um mini-pôster e quase todos os grupos concluíram a tarefa e colocaram no mural. Poucos grupos que não terminaram não queriam sair para o recreio sem terminar, queriam continuar fazendo. Infelizmente o Inspetor teve que retirá-los de sala pois ele deve trancar a sala nesse momento. Isso é um absurdo: tem que trancar e expulsar os alunos que querem trabalhar, alguém entende??? Interessante: alunos VERDADEIRAMENTE engajados, que preferem ficar em sala e finalizar ao trabalho ao invés de ir para o Recreio.

Essa invenção do teacher counter rendeu... Uso muito até hoje. Facilita o meu trabalho e eles se viram nos 30. Eu é que exagero nas tarefas... Pura empolgação...

E o trabalho da turma resultou em um pôster lindo, cheio de emoção, para a sessão de pôsteres no nosso evento de 2011: Friendship

E tudo começou porque o grammar point do livro era past tense e eu buscava um modo de trabalhar os verbos com eles. Um dia me deparei com um grupo grande (depois da aula, no ponto de ônibus) conversando, se abraçando, o maior carinho...

\section{Dia 16 de novembro}

Não pude ir.

\section{Dia 23 de novembro}

Fui inadvertidamente. $\mathrm{E}$ foi dia de prova. As provas foram em duplas

Eu não me lembro do dia. Mas é interessante porque a prova faz parte. Por que não há anotações??? Como foi feita? Como a professora trabalhou esse momento? E porque a professora não se lembra???? Ah, a eterna questão: a avaliação... os resultados / o produto/ os índices/ a meta. Será??? 


\section{6}

\section{Anexo VI}

Comunicação pessoal, via e-mail, dia 26/09/2011, quando Walewska me enviou um relato sobre como ela e os alunos avaliaram o trabalho ocorrido no terceiro bimestre. Os nomes com asterisco foram trocados.

Vanessa querida,

Estou mandando os comentários dos meus queridos sobre o bimestre. E você muito contribuiu com o trabalho que todos fizemos. Acho que você percebeu como os danadinhos nos envolvem, é um carinho aqui, um elogio ali, um segredinho... Pois foi o que você fez em todas as suas visitas (lembra quando você notou que a Luana* da Turma 2 não estava na aula?) Muito legal quando entendemos que TODOS são importantes, e cada qual do seu jeito contribui para que todos aprendam: isso é educar!!!!

E o que eles dizem???

Pois, veja vc, Vanessa querida: eles dizem que gostaram de trabalhar, que aprenderam, que foi legal!!!! Alunos de escola municipal, adolescentes... não são aqueles que não querem nada, não fazem nada, não têm jeito?????? Pois eu tenho você como testemunha!!! Quem vai acreditar que o Paulo* e o José* da Turma 2 deixaram as cartas de lado e pesquisaram (usaram o celular, e daí?) , fizeram mural, recortaram e colaram???? Como é que até agora não tínhamos percebido o talento do Mauro* da Turma 1 para o desenho, o menino é incrível!!! Ah, sim, o grupo do Renato*, Cauã* e etc... não fez os trabalhos, enrolou o tempo todo ( mas eu sei que estão LOUCOS, disputando as atenções da Mariana*, femme fatale, que nada quer com eles, mas estimula a disputa... adolescer não é fácil!!!) mas... na última hora se mexeu (a nota, a prova!!!) e eles quase conseguiram fazer tds as tarefas do bimestre! Quem vai acreditar que eles vinham atrás de mim para pedir os trabalhos que faltavam (ou que não fizeram no dia)? Podem duvidar de tudo... mas eu não estou nem aí, eu tenho meus EP secrets...

Imagina como me senti ao ler que as aulas são alegres; que os trabalhos ajudaram os alunos a se enturmarem, que entrevistar os funcionários foi legal...Muito feliz, claro, mas o bom é ver que eles percebem tudo e... percebem que a professora acredita neles, e que se a sala de aula tem seus momentos not so good,tem tb os good moments, tem muito trabalho e isso é bom, tem gente aprendendo... E o humor??? E a alegria??? 
Ah, como eles trabalharam! Você viu, Vanessa! E eles sabem tudo: é muito trabalho mesmo, tenho que me segurar, mas vou me empolgando e quando vejo, tem inspetor na porta ou a saída deles atrasa... Tenho que rever isso mesmo! Eu estava achando isso e eles, zás, confirmaram.

E agora vamos ao último bimestre: é hora de trabalhar as apresentações para o grupo (gosto também que eles apresentem o que fazem nas turmas do primário). Aí nosso desafio: eles trabalham bastante, trocam as informações, as "respostas". Assim, meio escondido, 'cola' mesmo. E por que não reconhecer esse modo de aprender? Os trabalhos do mural fazem isso: o mural registra o que todos aprenderam, mas é frio, é parado, é descartável! Vamos trabalhar para que eles mostrem os trabalhos, comentem , troquem, partilhem... Bom sambinha pela frente!

Credo! e eu só ia te mandar os comentários deles...

Ah, Vanessa, antes que eu me esqueça; na $5^{\text {a }}$ eu vou com a prof de E. física fazer uma caminhada no Caminho Cláudio Coutinho, na Urca, com as turmas da tarde. Saímos da escola ás 13 horas, acho que vc não chega a tempo... Então, nos vemos na próxima $5^{\mathrm{a}}$, allwright???

bjs

Walewska 